Historic, Archive Document

Do not assume content reflects current scientific knowledge, policies, or practices. 

Misc. $\mathrm{RL}-1$ Issued October $15,1917$.

U. S. DEPARTMENT OF AGRICULTURE

FOREST SER VICE HENRY S. GRAVES, Forester

\title{
GUIDEBOOK FOR THE IDENTIFICATION OF WOODS USED FOR TIES AND TIMBERS
}

\author{
BY \\ ARTHUR KOEHLER \\ EXPERT IN WOOD IDENTIFICATION \\ FOREST PRODUCTS LABORATORY \\ MADISON, WISCONSIN
}




\section{FOREST SERVICE.}

HENRY S. GRAVES, Forester.

ACBERT F. POTTER, Associate Forester.

\section{BRANCH OF RESEARCH.}

EARLe H. Clapp, Assistant Forester, in charge.

Forest Products Laboratory.

Carlite P. Winslow, Director.

Ovid M. Butler, Assistant Director.

SECTION OF TIMBER PHYSICS.

H. D. Tremann, in charge.

ARTHUR KoeHLer.

\section{United States}

Department of

Agriculture

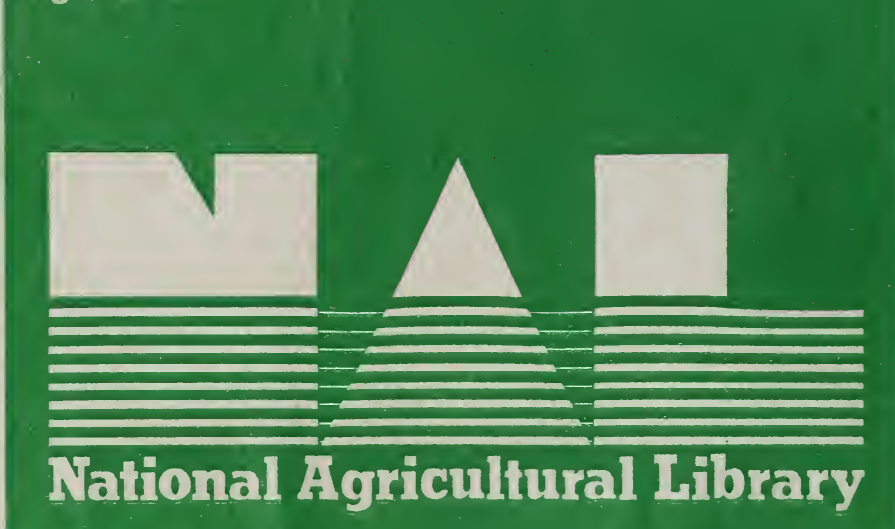





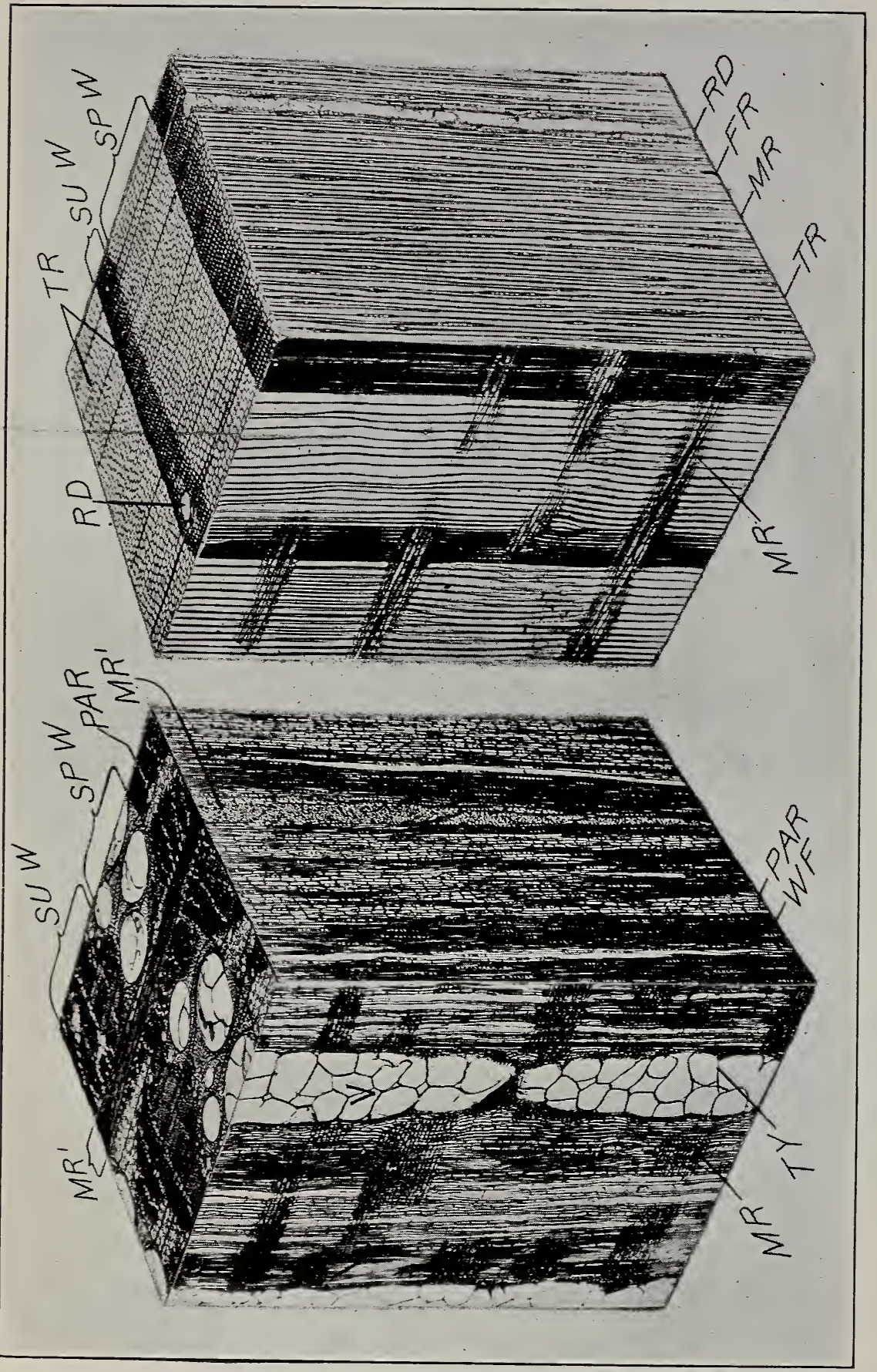


U. S. DEPARTMENT OF AGRICULTURE

F OREST SER VICE

HENRY S. GRAVES, Forester

\section{GUIDEBOOK}

\section{FOR THE IDENTIFICATION OF WOODS USED FOR TIES AND TIMBERS}

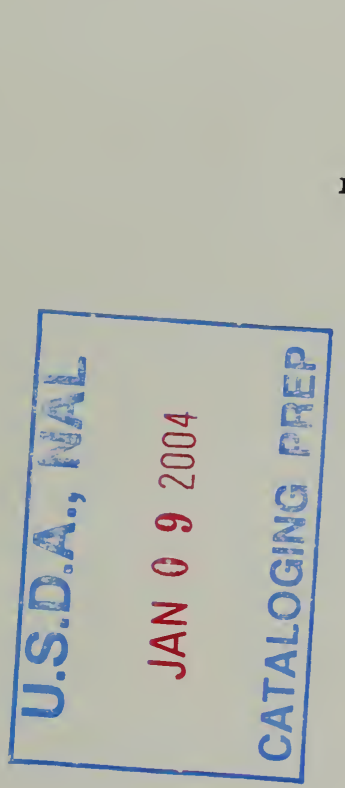

BY

ARTHUR KOEHLER

EXPERT IN WOOD IDENTIFICATION

FOREST PRODUCTS LABORATORY

MADISON, WISCONSIN 


\section{CONTENTS.}

Introduction Page.

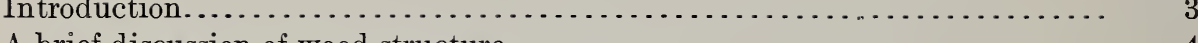

A brief discussion of wood structure........................... 4

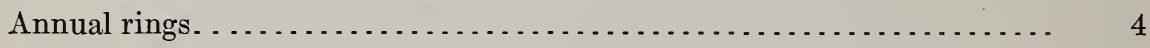

Structure of hardwoods................................. 5

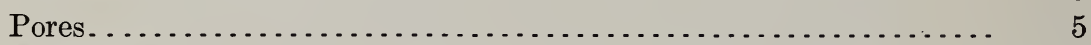

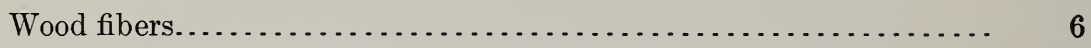

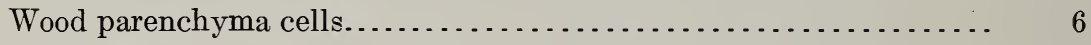

Medullary rays. . . . . . . . . . . . . . . . . 6

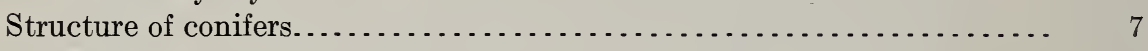

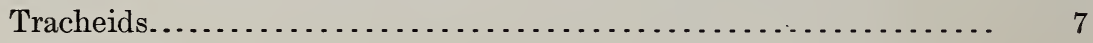

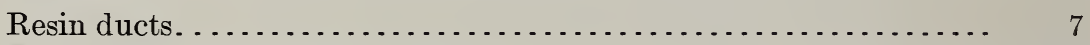

Wood parenchyma or resin cells......................... 8

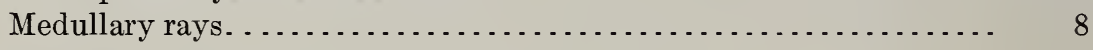

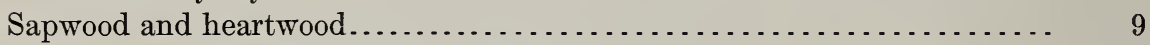

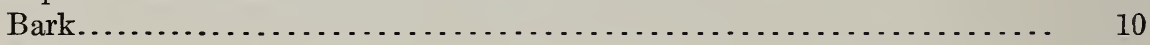

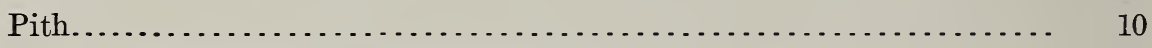

Physical properties useful in identifying woods.................... 11

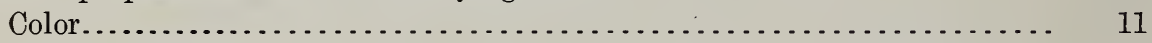

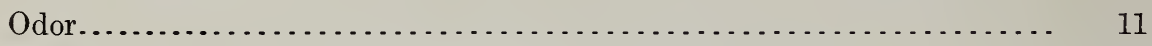

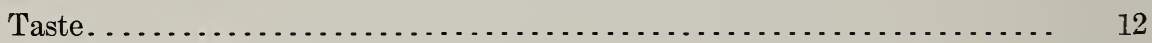

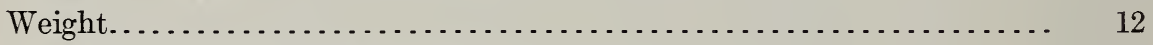

How to proceed in identifying wood......................... 13

The distribution maps aid in identification. . . . . . . . . . . . . 15

How to use the keys. ................................... 17

Key for the identification of woods without the aid of a hand lens . . . . . . . 19

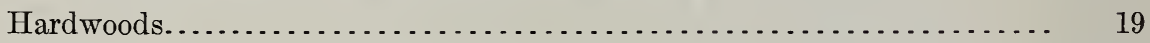

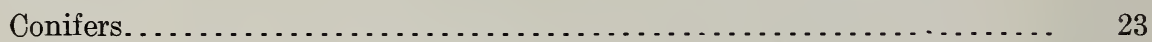

Key for the identification of woods with the aid of a hand lens. . . . . . . . . 27

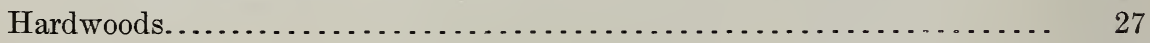

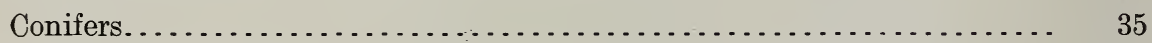

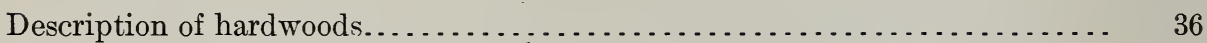

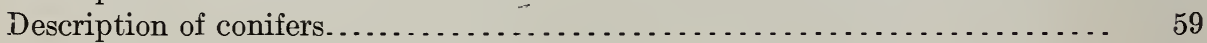

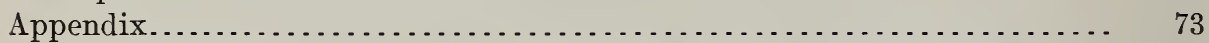

A method of distinguishing longleaf from shortleaf and loblolly pine ties . $\quad 73$ 


\section{GUIDEBOOK FOR THE IDENTIFICATION OF WOODS USED FOR TIES AND TIMBERS.}

\section{INTRODUCTION.}

The purpose of this guidebook is to point out the differences which are of practical value in the identification of the various species of native woods used for ties and timbers. It is intended primarily for inspectors; but since it includes most of our commercial species, it will, no doubt, be serviceable to others.

The identification of wood by general appearance requires long experience and is a method difficult or impossible to describe to an inexperienced man. Furthermore, with the growing use of wood preservatives and the closer utilization of our forest resources the number of species used for ties is increasing, and inspectors are called upon to be familiar with a larger number of woods. Experienced inspectors may be able to determine the kind of wood in most of the ties they commonly handle by the color and general character of the wood; but in case of doubt as to the species it is necessary to look for more specific distinctions.

The structure of wood offers the most reliable means for its identification, though odor, taste, weight, and hardness may be helpful. A detailed study of wood structure requires the use of a high-power microscope, which is impracticable for field work, such as the inspection of ties. However, by observing such characteristics of woods as can be seen with the naked eye, or, better yet, with a hand lens, a very satisfactory scheme of identification can be worked out.

Two keys which provide systematic aid in identifying wood are included in this guide. The keys are followed by a more detailed description of the woods, together with photomicrographs ${ }^{1}$ of the cross sections of the woods magnified 15 diameters and maps showing the range of each species described. Before using the keys or consulting the descriptions of the woods, however, it is necessary to understand the common terms used when speaking of the structure of wood. The following explanation of these terms is confined to such details as will assist in recognizing the elements, or cells, in the illustrations, and later in the wood itself. ${ }^{2}$

\footnotetext{
1 The photomicrographs are made by light passing through thin sections of wood. By this method the cells can be shown more clearly than by photographing the end of a picce of wood by reflected light.

2 For a detailed discussion of wood structure see Division of Forestry Bulletin 10, "Timber." It may be obtained from the Superintendent of Documents, Government Priuting Office, Washington, D. C., for 10 cents; stamps not accepted.
} 


\section{A BRIEF DISCUSSION OF WOOD STRUCTURE.}

Wood is composed of cells similar to those of a honeycomb, but the wood cells are very much smaller, they vary more in size and shape, and are, with the exception of true vessels, closed at both ends. The relative size and arrangement of the cells is fairly constant in the wood of each species but varies in different species, and forms a reliable means of distinguishing one wood from another.

\section{ANNUAL RINGS.}

Each year a tree adds just beneath the bark a layer of wood on the outside of that previously formed. In trees grown in a temperate climate the cells formed at the beginning of each year's growth

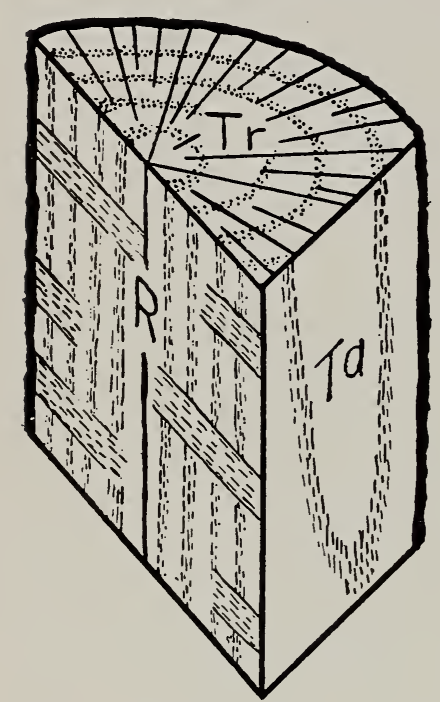

Fig. 1.-A block of wood showing, $\mathrm{Tr}$, tranverse, or end surface; $R$, radial, or "quartered" surface; Ta, tangential, or "bastard" surface. are larger than those formed later in the season. This difference in the size of the cells makes a sharp contrast between the last wood formed during a season and the first wood formed the next spring, thus producing a definite boundary for each year's growth. On a transverse surface these well-defined layers of wood appear as concentric bands, known as annual rings.

The soft, open wood formed in the spring is known as the springwood and the harder and denser wood formed later in the season is known as the summerwood. (See Plate I.) In some woods (classed as diffuse-porous woods), such as birch, maple, and gum, the distinction between springwood and summerwood is not clear.

Some species, such as the red oaks, cottonwood, willow, catalpa, and loblolly pine, usually have wide annual rings, and others, such as the white oaks, sugar maple, arbcrvitæ, and longleaf pine, habitually have narrow rings; but it is not advisable to place too much emphasis on the width of the rings in identifying wood. Rate of growth, which determines the width of the rings, is largely dependent in any species upon the soil, climate, and forest in which it grows.

Wood can be cut in three distinct planes with respect to the annual rings. The end surface of a piece of wood shows a cross section of the annual layers of growth. This is also known as the transverse surface. (See fig. 1.) It shows the size and arrangement of the cells better than any other surface. The illustrations of various species in the back of this handbook are all reproductions of photographs of cross sections. ${ }^{1}$ When wood is cut lengthwise

1 In each illustration the upper edge is the side toward the bark 
through the center or pith of the tree, the surfaces exposed are known as the radial, or "quartered," surfaces. A longitudinal surface which does not pass through the center is known as the tangential, or "bastard," surface. Plain sawed lumber is tangentially cut. Technically, a tangential surface is at right angles to the radius.

\section{STRUCTURE OF HARDWOODS.}

PORES.

Pores are hollow tubes composed of comparatively large cells with open ends, set one above the other. Technically they are known as vessels. Pores are confined almost entirely to the hardwoods, ${ }^{1}$ or woods from broad-leaved trees. For this reason the hardwoods are also called porous woods. In the conifers the cells are all closed at the ends, and do not form vessels. For this reason, the conifers are classed as nonporous woods. (See Plate I and plates in the back of this guidebook.)

In coarse-textured or so-called "open-grain" ${ }^{2}$ woods, such as oak, ash, and walnut, some of the pores are plainly visible to the unaided eye; but in finer-textured woods, such as beech, maple, and basswood, they are visible only with a good hand lens.

In some hardwoods the pores are comparatively large at the beginning of each annual ring, and decrease in size more or less abruptly toward the summerwood, thus forming a distinct porous ring in the springwood. Such woods are classed as ring-porous woods. Oak, chestnut, ash, and elm are examples of this class. In other hardwoods the pores are of practically uniform size throughout the annual ring, or decrease slightly toward the outer portion of the summerwood. Such woods are known as diffuse-porous woods. Birch, gum, poplar, and maple are examples of this class. The pores in the summerwood of ring-porous woods are arranged in various ways. These variations are described in the keys and aid in classifying the woods according to structure.

Tyloses.-The pores of some woods, except those in the outer sapwood, are filled with a frothlike growth called tyloses. These are

\footnotetext{
1 The tcrms hardwoods and softwoods or conifers are not exactly correct designations for the two large classes of woods; for some so-called softwoods are harder than some so-called hardwoods, and some so-called conifers do not bear cones. Other designations, such as porous and nonporous woods, woods from deciduous and woods from evergreen trees, woods from broad-leaved trecs and woods from trecs with needle or scalelike leaves, are also inexact because cxceptions are found in both classes. The botanical terms angiospcrms (meaning secds inclosed in an ovary) for hardwoods, including palmlike trees, and gymnosperms (meaning seeds not inclosed in an ovary) for softwoods or conifers are correct but are not in common usage. To obviate the use of the word softwoods in distinction from hardwoods and yet use simple terms understood by all, the words hardwoods and conifers will be used in this publication to designate the two large classes of woods.

2 "Tcxture" is used in preference to "grain" to indicate the size of the pores in hardw oods, or the tracheids in conifers, as fine-texturcd and coarse-textured. Woods in which there is a dccided difference in the density of the springwood and summerwood are said to have an uncven texture; others, in which the density is more uniform, are said to have an even texture. "Grain" is uscd with respect to the direction of the fibers, as straight grain, cross or interlocked grain, and bird's-eye grain; it does not refer to the width of the annual rings, nor to the size of the pores or tracheids.
} 
formed by ingrowths from the neighboring cells (parenchyma), and fill the pores more or less like so many toy balloons crowded into an air shaft. (See the oak cube in Plate I.) Tyloses are especially abundant in black locust, osage orange, mulberry, and the whiteoak group.

WOOD FIBERS.

Most of the denser, harder part of hardwoods is composed of very narrow, comparatively long, thick-walled cells known as wood fibers. As a rule, these fibers are too small to be separately distinguished with a hand lens, and their arrangement is rarely used for identification purposes. The conifers have no true wood fibers. (See Tracheids, p. 7.)

\section{WOOD PARENCHYMA CELLS.}

Wood parenchyma cells are comparatively short, usually thinwalled cells too small to be seen individually without a compound microscope. Collectively, they may be recognized on the cross section by the light-colored tissue they form. In some hardwoods the parenchyma cells are so scattered that they are not noticeable; for example, in cottonwood, elm, and maple. In hickory and persimmon they form fine light-colored tangential lines. In some species the parenchyma surrounds the pores causing a "halo" to appear around them, as in sassafras and black ash. In white and green ash the parenchyma surrounds the pores and projects in tangential lines. In yellow poplar and the magnolias the parenchyma is confined to a narrow layer on the outer portion of each annual ring.

Pith flecks are abnormal groups of parenchyma cells appearing on the end surface of some woods as small discolored spots, and as darkened streaks on the longitudinal surface. They are caused by larvæ of insects burrowing in the young wood under the bark, the passages being later filled up by parenchyma cells. Pith flecks are very abundant in river birch (the illustration in Pl. XVII, fig. 2, shows one pith fleck at the lower edge) and are also found in cottonwood, cherry, red and silver maple, basswood, and a few other species. The presence or absence of pith flecks should not be relied upon too much in identifying woods. However, if a piece of birch is found to contain numerous pith flecks, it is a good indication that the specimen is not sweet or yellow birch. If the flecks are found abundantly in a piece of maple, it indicates that the specimen is not sugar maple.

\section{MEDULLARY RAYS.}

Medullary rays, also known as pith rays or rays, are narrow bands of cells extending radially in a tree, from the bark inward at right angles to the grain. (See Plate I.) Some of the rays in the oaks are com-

1 For a detailed discussion of the cause and occurrence of pith flecks, see Forest Service Circular 215,

"Pith-ray Flecks in Wood." This may be obtained from the Superintendent of Documents, Government Printing Office, Washington, D. C., for 5 cents; stamps not accepted. 
paratively wide and conspicuous, giving the beautiful "silver grain" to quartered oak. They are also very plain in sycamore, beech, maple, and cherry. In some woods they are so fine that they are inconspicuous on the radial surface and not visible on the end surface without a lens. Cottonwood, buckeye, chestnut, and cotton gum or tupelo are woods of this class. The width of the medullary rays is often an important aid in distinguishing one wood from another.

In some woods the rays are arranged in tiers or stories one above the other, appearing on the tangential surface as very fine bands running across the grain. Moistening the surface brings out these bands more clearly in some woods. This arrangement of the rays is known as storied rays. It is characteristic of buckeye and serves to distinguish it from other light woods, and also of persimmon, which can thereby easily be distinguished from hickory, which it resembles.

\section{STRUCTURE OF CONIFERS.}

Conifers differ in structure from hardwoods in the absence of pores and true wood fibers, the radial arrangement of the fibrous cells (tracheids), and the presence of resin ducts or resin cells in some groups. (See Plate I.)

TRACHEIDS.

Most of the wood of the conifers is made up of tracheids, which are elongated cells that take the place of both the pores and the wood fibers of hardwoods. The tracheids are narrower in cross section than most pores and wider than most wood fibers of the hardwoods. With a good hand lens, a smoothly cut end surface, and good light, the tracheids can be seen in most coniferous woods. They are practically uniform in tangential diameter and are arranged in definite radial rows. In the outer part of each annual ring the tracheids become somewhat flattened radially and thicker walled, producing a harder and darker band of summerwood. In the hard pines, larches, and Douglas fir, the summerwood is very conspicuous and because of its density adds greatly to the strength of the wood.

\section{RESIN DUCTS.}

The woods of the pines, spruces, larches, or tamaracks, and Douglas fir contain resin ducts, which are more or less continuous passages extending parallel to the grain, vertically, and, within certain medullary rays at right angles to the grain, horizontally in a tree. The vertical resin ducts may be seen with a lens, and in some of the pines usually without a lens, on a smoothly cut end surface, where they appear as darker or lighter colored specks or small pores. They should not be confused with the pores or vessels of hardwoods, which are much more numerous and serve an entirely different purpose. The horizontal resin ducts are smaller than the vertical 
ducts and are not easily seen with a hand lens. (See Medullary Rays, below.)

Pitch pockets, resin streaks, and exudations of resin on an end surface are a positive indication of the presence of resin ducts, and do not occur in hemlock, cedar, cypress, redwood, and the true firs. ${ }^{1}$ The absence of such accumulations of resin, however, does not necessarily mean the absence of resin ducts in the wood. Resin will not exude, as a rule, on cuts made after the wood is seasoned, but warming pieces of pine, Douglas fir, tamarack, and spruce in an oven will usually cause enough resin to exude on the ends to form specks, thereby indicating the presence of resin ducts. This is especially true of the pines and Douglas fir. On a longitudinal surface exposed to the air for some time the resin ducts often appear as brownish lines. This is especially characteristic of the pines.

Western hemlock, redwood, and some of the true firs occasionally develop abnormal vertical resin ducts in places where the tree has been injured. In such cases the ducts usually are in tangential rows from one-eighth to an inch or more in length. (See illustration of white fir, Pl. XXVIII, fig. 2.)

\section{WOOD PARENCHYMA OR RESIN CELLS.}

Wood parenchyma in conifers is scarce. It forms a layer of one or two cells around the resin ducts, but is inconspicuous and not used in making identifications without a high-power microscope.

In cypress and redwood, parenchyma cells (usually referred to as resin cells), containing a brownish gum, are scattered throughout the annual rings. (See illustrations of cypress, Pl. XXX, fig. 2, and of redwood, Pl. XXX, fig. 1.) In redwood they are not easily noticed because of the dark color of the wood; in cypress they are often conspicuous, especially on longitudinal surfaces, where they appear as dark lines or bands. Resin cells are also found in the cedars, but usually they are more scattered.

\section{MEDLLLARY RAYS.}

The rays in conifers are very narrow, excepting those containing horizontal resin ducts, which are slightly wider. These wider rays are termed fusiform rays and are found only in the pines, spruces, larches, and Douglas fir. (See illustrations of western yellow pine, Pl. XXIII, fig. 2, and Engelmann spruce, Pl. XXVI, fig. 1, and Plate I.) The fusiform rays occasionally help to determine the presence of resin ducts, especially in the spruces and larches, in which the vertical resin ducts are sometimes not easily found. On the radial surface the horizontal resin ducts may often be recognized as brownish lines, especially in the pines.

\footnotetext{
1 Resinous scars may appear locally in these woods, because of injuries inflicted on the growing tissues of the tree.
} 


\section{SAPWOOD AND HEARTWOOD.}

The end surface of a $\log$ usually shows an outer lighter eolored region, the sapwood, and an inner darker core, the heartwood. All young wood is light-colored; but as the tree becomes older the inner part becomes infiltrated with gums, resins, and other materials the exact nature of which has not been determined, which color the wood to a greater or less degree.

In some woods the heartwood is rery dark, and in others there is little difference in color between the sapwood and heartwood. The spruces, true firs (not Douglas fir), hemlock, Port Orford cedar, and buckeye belong to the latter class. In lodgepole pine, piñon, cottonwood, beech (white heart), cotton gum, sycamore, hackberry, and basswood, the heartwood is only slightly darker than the sapwood. The sapwood is often not white but is slightly tinged with the same color that is found in the heart wood. In black locust, honey locust, coffeetree, mulberry, and osage orange the sapwood is pale yellowish. The bark sometimes discolors the sapwood by leaching after the tree is cut. Sap stain imparts a biuish color to the sapwood, especially in the pines, hackberry, sugarberry, and red gum.

Douglas fir and western larch occasionally contain zones of lightcolored wood inside the heartwood. These zones are known as internal sapwood. They have been found to take preservative treatment as well as the outer sapwood.

The width of the sapwood varies with the age and vigor of the tree, the distance from the stump, and the species. Young and vigorous trees have wider sapwood than mature trees, although more annual rings are usually present in the sapwood of old trees because of thair slower growth in diameter. The sapwood dacreases in width from the stump to the top and often varies in different directions from the center, so that an annual ring may be sapwood in one part of a tree and heartwood in another.

Certain species normally have very narrow sapwood and others very widesapwood, and this feature often is useful in identifying woods.

Species with very narrow sapwood, usually less than 1 inch wide:

Black locust.

Osage orange.

Red mulberry.

Hardy catalpa.

Sassafras.

Coffeetree.

Slippery elm.

Black ash.

Butternut.

Black cherry.

Western larch.

Arborvitæ (Northern white cedar).

Western red cedar.

Piñon.
Species with very wide sapwood:

Loblolly p:ne.

Beech (white-heart).

White ash.

Green ash.

Hackberry.

Persimmon.

Hickory.

Maple.

Basswood. 


\section{BARK.}

Occasionally ties have part of the bark left on them, and this is a very valuable aid in identification. The bark varies considerably in appearance from the butt of a tree to the top and in different sizes of the same species. Therefore, it is difficult to describe the bark for each species. Careful observations, however, as to the character of the surface, color, and thickness of barks will go a long way in helping to identify ties. Some trees have fibrous or stringy barks, a few have a papery bark, others have a tight, rather smooth bark, but most trees have a ridged and furrowed bark separating into scales. Many trees have the bark smooth at the top, but rough on the rest of the trunk.

Trees with stringy outer bark:

Arborvitæ (Northern white cedar).

White cedar.

Western red cedar.

Port Orford cedar.

Bald cypress.

Redwood.
Trees with rather smooth bark:

White birch.

Yellow birch.

Sycamore.

Beech.

Aspen.

The true firs (Abies), except on very large trunks.

The bark of all true firs (Abies) has numerous blisters of resin on the surface, thereby distinguishing them from the spruces and, in fact, all other trees. There are occasional resin blisters on the bark of young trees of Engelmann spruce and Douglas fir, but they are not so numerous and conspicuous as in the true firs. Douglas fir and white fir (Abies concolor) have whitish layers in the bark, while the other firs (with a possible exception of alpine fir (Abies lasiocarpa)) have thin dark layers in the bark similar to those in hemlock bark. Lodgepole pine has little pockets of resin in the bark, which give it a "pocked" appearance when the bark scales off and distinguishes it from Engelmann spruce.

Part of the inner bark is often present on ties and helps to identify a species. It is well known that the inner bark of slippery elm becomes mucilaginous or slimy when chewed. The inner bark of sweet birch, and of yellow birch to a less extent, has a distinct wintergreen flavor, and that of black walnut and of butternut is exceedingly bitter. Some tie inspectors distinguish white oak from red oak ties by the more fibrous inner bark of the white oak. Yellow oak has a yellowish inner bark which distinguishes it from all other oaks used for ties.

\section{PITH.}

The pith is a small core in the structural center of the stem. It is usually of a darker color than the surrounding wood, but exceptions may be found. The pith is always very soft, being readily indented with the finger nail or pencil point. It varies in size from a core 
barely visible in cross sections to over one-fourth of an inch in diameter. It is valuable in distinguishing longleaf pine from shortleaf and loblolly pine (see Appendix, p. 73). The wood of the coffeetree is very similar in appearance to that of honey locust, but the coffeetree has a much larger pith than the honey locust. The pith of catalpa is usually distinctly three-comered; in black ash, the wood of which resembles catalpa, the pith is round.

\section{PHYSICAL PROPERTIES USEFUL IN IDENTIFYING WOODS.}

\section{COLOR.}

The color of wood is useful in the identification of species, but must not be relied on entirely, for it is variable in the same species, and in different species it often differs only in shade. Slight variations in color can not be satisfactorily expressed in writing, but comparison with known samples will often reveal the identity of a specimen. Most woods turn darker on exposure to air, therefore comparisons should always be made on freshly cut longitudinal surfaces.

Some woods can be identified at once by their color. The small, black heartwood of persimmon, resembling ebony, to which it is closely related, is found in no other native species. The chocolate brown color of black walnut; the lustrous red-brown of cherry; the dingy, reddish brown of red gum; the bright reddish hue of most Douglas fir; the uniform creamy yellow color of buckeye, are usually enough to distinguish these species.

Osage orange and black locust are much alike in structure, strength, durability, and color, although the former usually has more of a golden-brownish tinge. These two woods can readily be distinguished by the fact that osage orange gives off a yellowish color if wrapped in a wet rag or placed on a soaked blotter, while black locust gives off practically no color under the same conditions.

Preservatives, paint, or decay may, of course, so alter the appearance of wood that its natural color can not be determined.

Color is more or less an indication of durability. It is well known that the darker woods like redwood, juniper, black walnut, osage orange, and black locust, are more durable than such light-colored woods as cottonwood, maple, ash, beech, white fir, and spruce. Those cedars which have no very dark heartwood are an exception, and their durability is ascribed to certain resins and oils which the wood contains.

\section{ODOR.}

Many woods give off a characteristic odor when they are worked. Therefore, in order to determine the odor of wood, it should be whittled or, better yet, sawed and the sawdust held to the nostrils. The odor is more pronounced in the heartwood than in the sapwood. It is even more difficult to describe odor than color, so that authentic samples for comparison are of far greater value than pages of writing. 
Most of the pines have a distinct resinous odor. The cedars have an agreeable odor which reminds one of shingles; Port Orford cedar has a strong spicy odor, very noticeable when the wood is worked. Cypress has a mild rancid odor, which will always help one who is familiar with it to identify this wood no matter what the color or weight may be. Alpine fir has a rank odor when dry which distinguishes it from all other firs. Among the hardwoods, sassafras is easily recognized by its characteristic fragrance. Some oaks have a soured odor before they are dry. The odor of cottonwood is slightly disagreeable.

\section{TASTE.}

Taste is closely associated with odor but sometimes can more easily be recognized. Port Orford cedar has a spicy taste. Cypress and redwood have practically no taste, and through this characteristic can be distinguished from arborvitæ and western red cedar, which have a somewhat bitter taste. Sassafras wood tastes like the extract made from its roots and bark.

\section{WEIGHT}

Wood varies considerably in weight, the variation depending on the species, the conditions under which the wood is grown, the part of the tree from which it is taken, and the amount of moisture it contains. In speaking of the weight of wood, it should be specified whether green, air-seasoned, kiln-dried, or oven-dried wood is meant, and whether the weight is based on the volume when green or after shrinkage has begun. After ties have seasoned for a year or more and the greater part of the moisture has evaporated, the weight may serve to a certain extent to identify the wood.

The following classification is used in indicating the relative weight of each species described in this guidebook. Since the weight of each species of wood is variable, this classification will be found more descriptive, because it is comparative, than the giving of simply the average weight of each species:

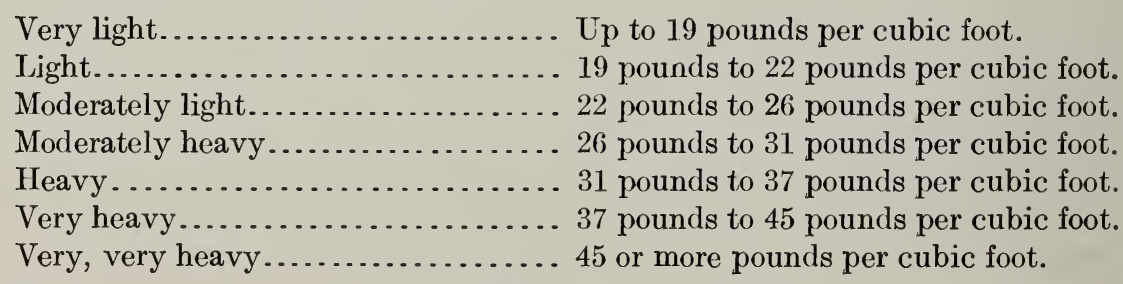

In each case the oven-dry weight based on the green volume is meant. In practice, allowance must be made for the moisture contained in the wood, which in ties may add from 15 to 60 per cent to the oven-dry weight. The volume when green may be obtained from green or resoaked specimens, and the oven-dry weight by drying the same specimens in an oven at $212^{\circ} \mathrm{F}$. till they cease to lose weight. 


\section{HOW TO PROCEED IN IDENTIFYING WOOD.}

Certain striking physical properties or peculiarities of structure will serve to identify some woods on casual inspection; but when this is not possible, a systematic scheme which points out essential differences in species or groups of woods must be followed. Such a scheme is commonly known as a key.

Two keys (beginning on pages 19 and 27, respectively) have been prepared, by means of which woods can be "traced down" and their identity determined. The first key is based on such details of the structure as may be seen with the naked eye, supplemented by differences in color, odor, weight, etc. In the second key such additional differences in the structure of wood as may be seen with a hand lens have been added. Obviously, the second key will involve less chance of error in identifying woods than the first key because more differences have been introduced. Therefore, inspectors are urged to become familiar with wood as seen under a hand lens. The photographs of cross sections of wood magnified 15 diameters which are inserted in the back of this guidebook together with careful observation of samples of wood correctly named will be found invaluable aids in recognizing the finer distinctions between the species. Specimens used for compari-

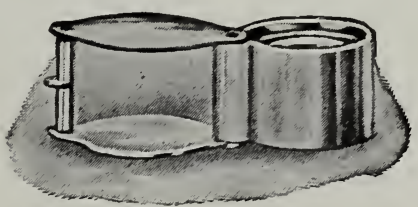

FIG. 2.-A good type of hand lens. son should be taken from the main body of a tree and not from limbs or stumps, for the structure in these parts is often slightly different from that in the trunk.

Wood which is to be observed for its structure should be cut smoothly across the grain with a very sharp knife. An inspector should provide himself, therefore, with a knife of good quality, one that will hold its edge well. Sandpapering or otherwise polishing the surface of wood will obliterate the character of the structure rather than make it more distinct.

He should also provide himself with a good hand lens, or pocket magnifier. Figure 2 is an illustration of a good type. A fairly good lens can be obtained for $\$ 1$ and an excellent one for $\$ 3.50$. Cheap lenses give low magnification, poor definition, and must be held closer to the object, thus shutting out the light to a greater extent than is necessary with a better quality lens of the same magnifying power. The magnifying power of the lens should be about 12 or 15 diameters, or from 144 to 225 times in area.

To get the best results with a lens it should be placed close to the eye and then the object brought up toward the lens till it is clearly visible. Care must be taken that the object examined is well illuminated. One inexperienced in the use of a hand lens is very apt so to 


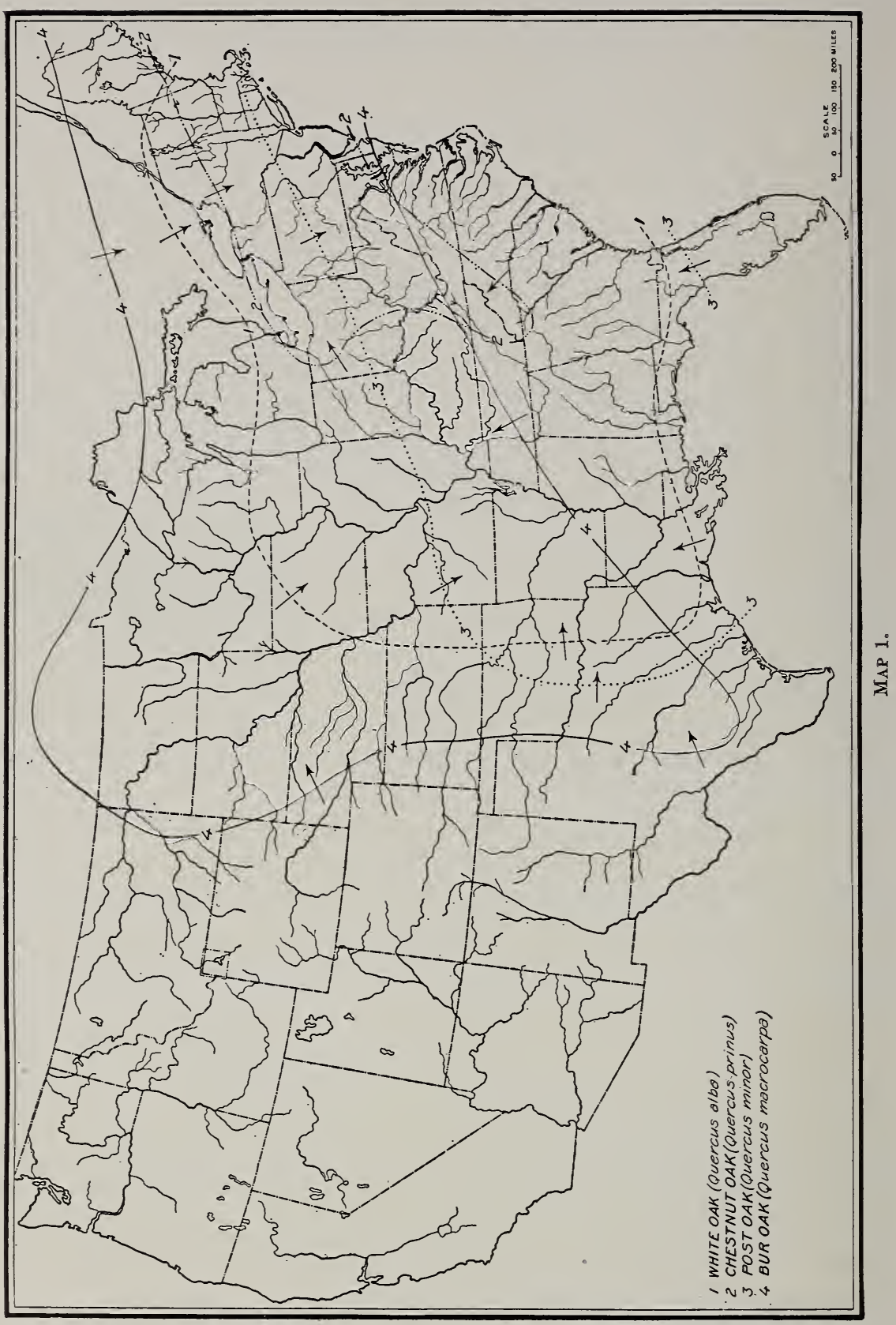


shade the surface of the wood with his hand, head, or hat that the structure can not be seen distinctly. In order to steady the hands it is best to rest the hand holding the lens on the object to be examined or on the other hand holding the object.

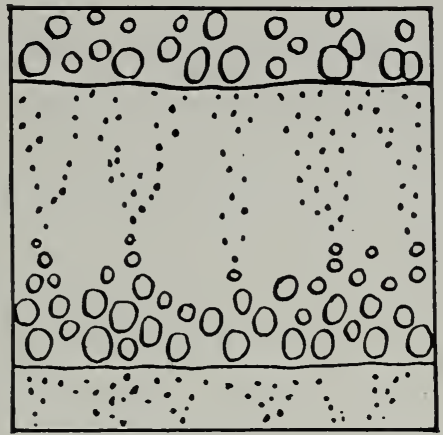

FIG.3.-A ring-porous wood with radial arrangement of pores in the summerwood.

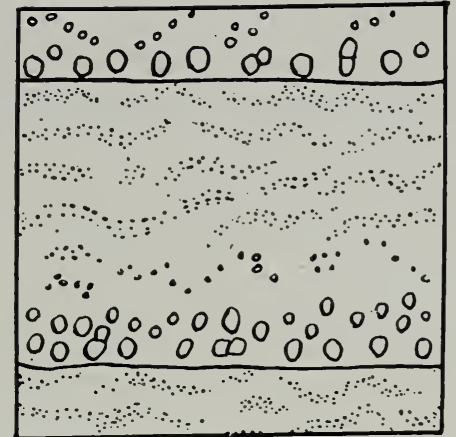

FIG. 4.-A ring-porous wood with wavy, tangential arrangement of pores in the summerwood.

The area which is cut smoothly for observation need not be large (about one-half inch square), but should contain annual rings of average width, preferably not near the center. In very narrow or very wide rings the characteristic structure of the wood is somewhat

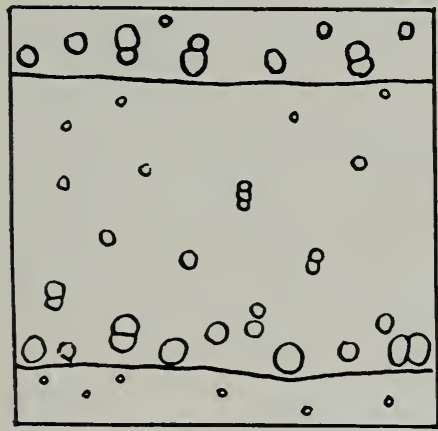

FIG. 5.-A ring-porous wood without definite arrangement of pores in the summerwood.

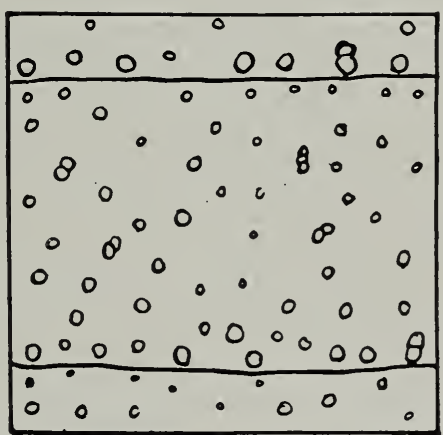

FIG. 6.-A diffuse-porous wood.

modified and does not serve so well for identification purposes. Slightly moistening the surface often brings out the features to better advantage.

\section{THE DISTRIBUTION MAPS AID IN IDENTIFICATION.}

The keys can often be simplified by eliminating all those species that an inspector is sure he will not have occasion to inspect in a given locality. The regions in which the species herein described grow are indicated by lines on maps 1 to 11 , inclusive. ${ }^{1}$ The

\footnotetext{
1 These maps were prepared by Mr. W. H. Lamb and Miss G. E. Wharton, of the Section of Forest Dis-
} tribution, Forest Service. 


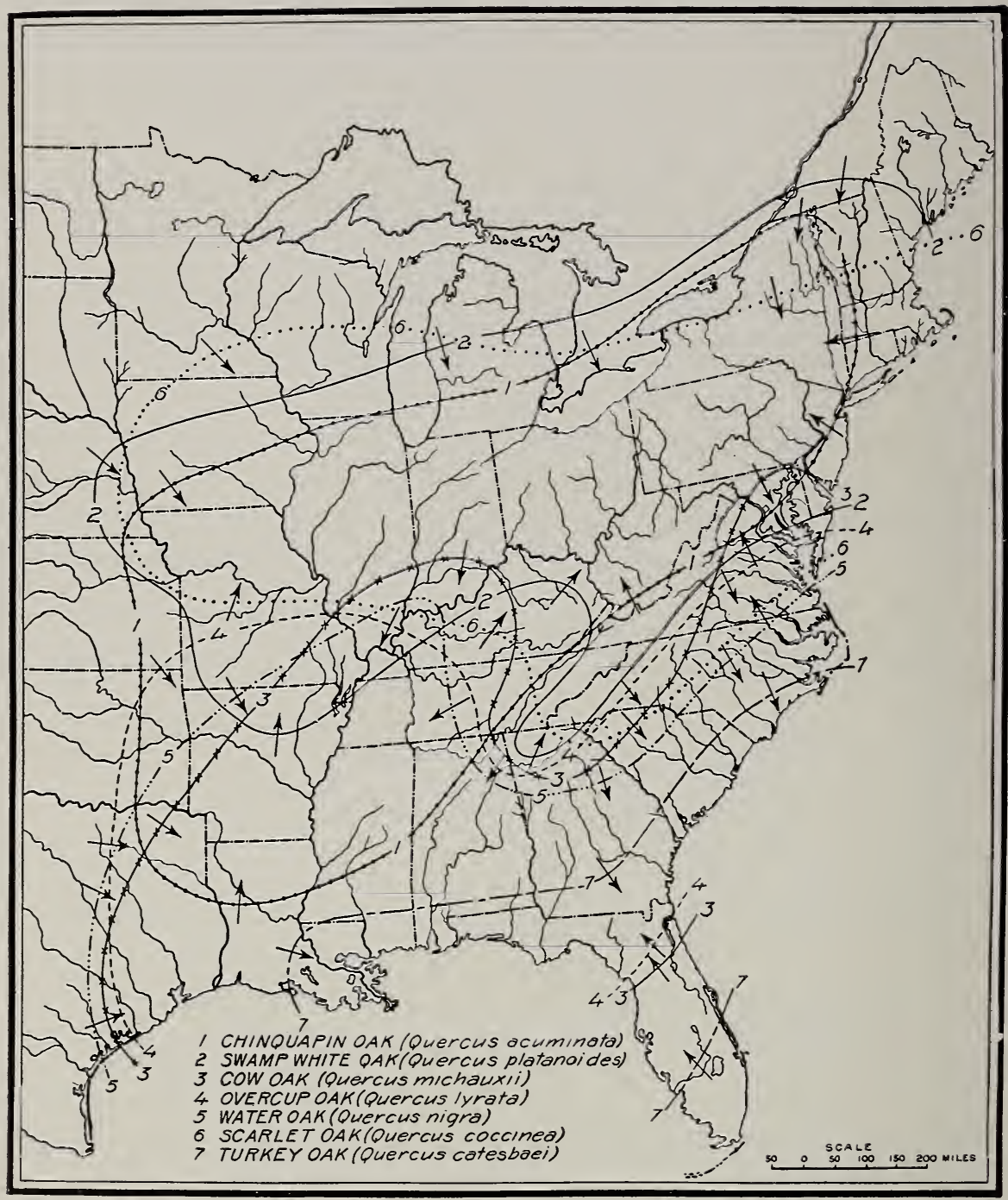

MAP 2. 
arrows indicate on which side of the line the species is found. If the origin of a piece of wood is known, reference to the maps will often make it clear that it could not be a particular species which it otherwise resembles. For instance, western red cedar and arborvitæ are very similar in structure and physical properties but they grow in widely separated regions.

\section{HOW TO USE THE KEYS.}

It will be noticed that the first differences brought out in the keys are based on the presence or absence of visible pores whether observed without a lens as in the first key or with a lens as in the second key. By this means woods can be grouped into two distinct classes, which could not be done so satisfactorily if the main distinctions were based on color, weight, odor, or other physical properties. Further divisions are made according to structure or physical properties, whichever shows the more easily observed and reliable differences.

Let us take, for example, a piece of wood presenting structural features similar to those in the illustration in Plate XIV, figure 1. If we are without a hand lens and examine the smoothly cut end surface with the naked eye, we find that no pores are visible. This at once throws it into the second group of the first key, "II. Pores not visible," page 23. On further examining the end surface we see the medullary rays very plainly; in fact, they are "comparatively broad and conspicuous." This makes it evident that the wood belongs to group A under II, and is either sycamore or beech. We notice the rays are "not crowded" and there is a "distinct denser and darker band of summerwood present." The wood is identified as beech.

If we use a hand lens and the second key, we must class the wood under the first group, "I. Wood with pores," page 27 , because pores can be seen with the aid of a lens. The annual rings do not contain a definite ring of large pores on the springwood; therefore, it would be classed as "B, Diffuse-porous," page 31. On examining the rays we find that the widest ones are fully two times as wide as the largest pores. (This distinction is more definite than that in the first key, which states that they are "comparatively broad and conspicuous.") Again we come to the alternative that it is either sycamore or beech. If we look carefully with a lens, we find that only part of the rays are broad, the others are much narrower than the pores. (This distinction also is more definite than "rays not crowded" as in the first key.) The wood is again identified as beech and the inspector has reason to feel more confident that his identification is correct because of the finer distinctions brought out with a hand lens.

The inspector will find the hand lens especially valuable in distinguishing between the red oaks and the white oaks.

$96625^{\circ}-17-2$ 


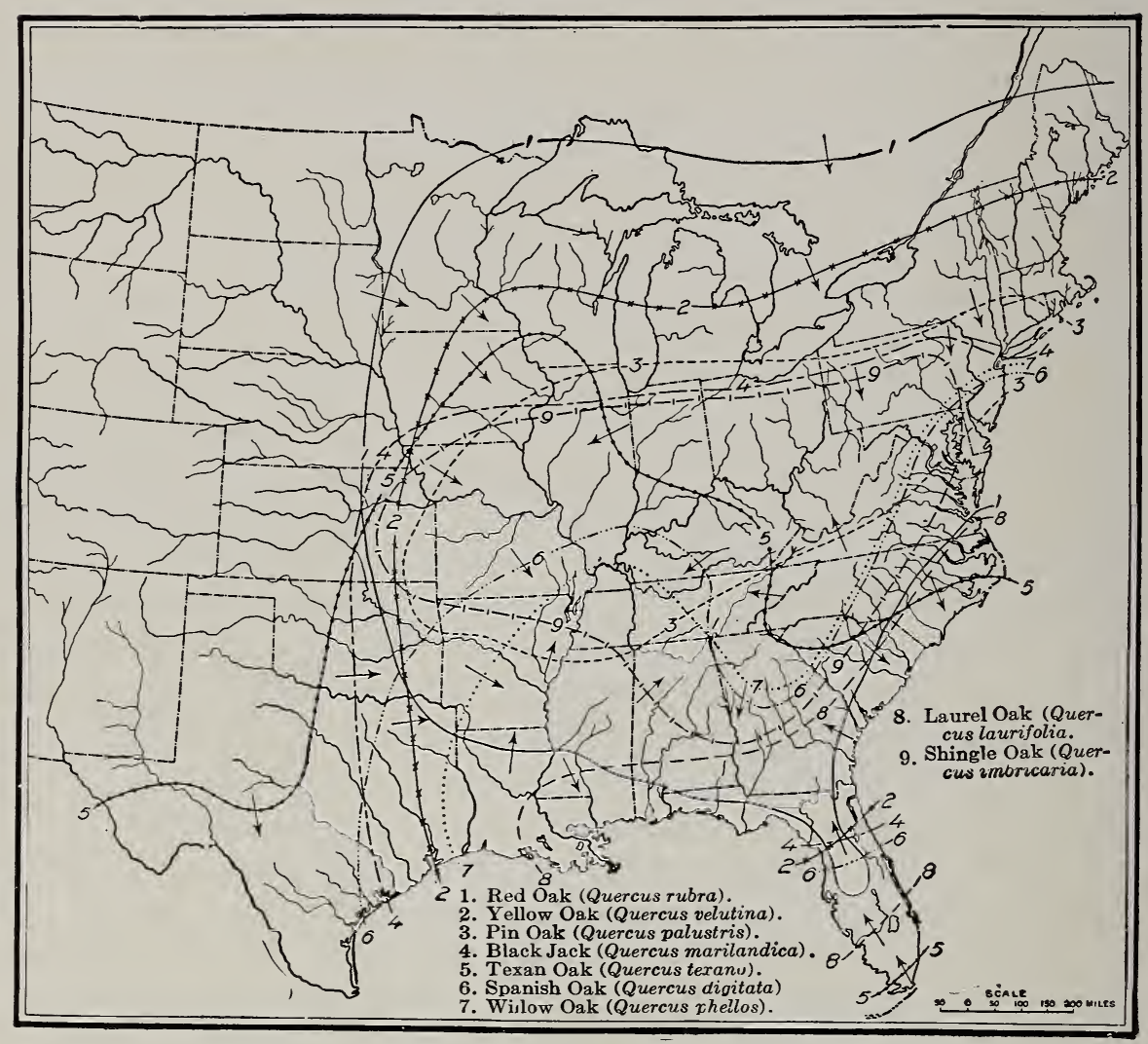

MAP 3. 
It will be noticed that some woods are mentioned more than once in the keys. This arrangement has been found necessary whenever the characteristics of a species place it close to the line of demarcation between two groups. In such cases, because of the variability of wood structure and because of the personal interpretation that may be given to the keys, the wood may reasonably be classed under either one of the groups under which it occurs in the keys. It is therefore placed in both in order to facilitate identification.

\section{KEY FOR THE IDENTIFICATION OF WOODS WITHOUT THE AID OF A HAND LENS. ${ }^{1}$}

I. Pores visible.

\section{HARDWOODS.}

A. Ring-porous; that is, the pores at the beginning of each annual ring are comparatively large, forming a distinct porous ring, and decrease in size more or less abruptly toward the summerwood. See figures 3,4 , and 5 . (This feature is often more distinct in the outer sapwood where the pores are more open.)

1. Summerwood figured with wavy or branched radial bands. See figure 3.

AA. Many rays broad and conspicuous. Wood heavy to very heavy.. The OAKS, p. 36.

(a) Wood without reddish tinge. The large pores mostly closed up (exception, chestnut oak)...................... The WHITE-OAK GROUP, p. 37.

(b) Wood with reddish tinge, especially near knots. The large pores mostly open (exception, black jack oak)............. The RED-OAK GROUP, p. 39.

BB. Rays not noticeable. Color grayish brown. Wood moderately light.

CHESTNUT, p. 41.

2. Summerwood figured with short or long wavy tangential lines or bands, in some woods more pronounced toward the outer part of the annual ring. See figure 4.

AA. The heartwood not distinctly darker than the sapwood (the sapwood may be darker than the heartwood on account of sap stain). The wavy tangential bands conspicuous throughout the summerwood. Color yellowish or greenish-gray Wood moderately heavy............................HACKBERRY, p. 43. SUGARBERRY, p. 43.

BB. The heartwood distinctly darker than the sapwood.

(a) Wood with spicy odor and taste; moderately heavy. Heartwood silvery brown ................................................

(b) Wood without spicy odor or taste.

(a) Heartwood bright cherry red to reddish brown. Pores in springwood all open and very distinct. Sapwood narrow. Wood very heavy.

(a3) Pith large, usually over 0.2 and often about 0.3 inch in diameter. COFFEETREE, p. 46.

(b3) Pith small, usually under 0.15 and often less than 0.1 inch in diameter........................ HONEY LOCUST, p. 45.

(bb) Heartwood russet to golden brown. Pores entirely closed up except in outer sapwood. Sapwood very narrow.

(a3) Wood from very heavy to very, very heavy and exceedingly hard. Tangential bands confined to, or more pronounced in, the outer portion of the annual ring. Rays barely distinct.

(a4) Heartwood golden brown with reddish brown streaks; yellowish color imparted in a few minutes to a wet rag or blotter..................... OSAGE ORANGE, p. 43.

(b4) Heartwood russet brown without reddish brown streaks; color not readily imparted to a wet rag or blotter.

BLACK LOCUST, p. 44.

(b3) Wood lighter but still classed as heavy and hard. Tangential bands uniformly distributed throughout the summerwood. Rays very distinct...............RED MULBERRY, p. 44.

1 Unless it is otherwise directed, all observations as to structure should be made on the end surface of rings of average width, cut smoothly with a very sharp knife; and all observations as to color should be made on a freshly cut longitudinal surface of the heartwood. 


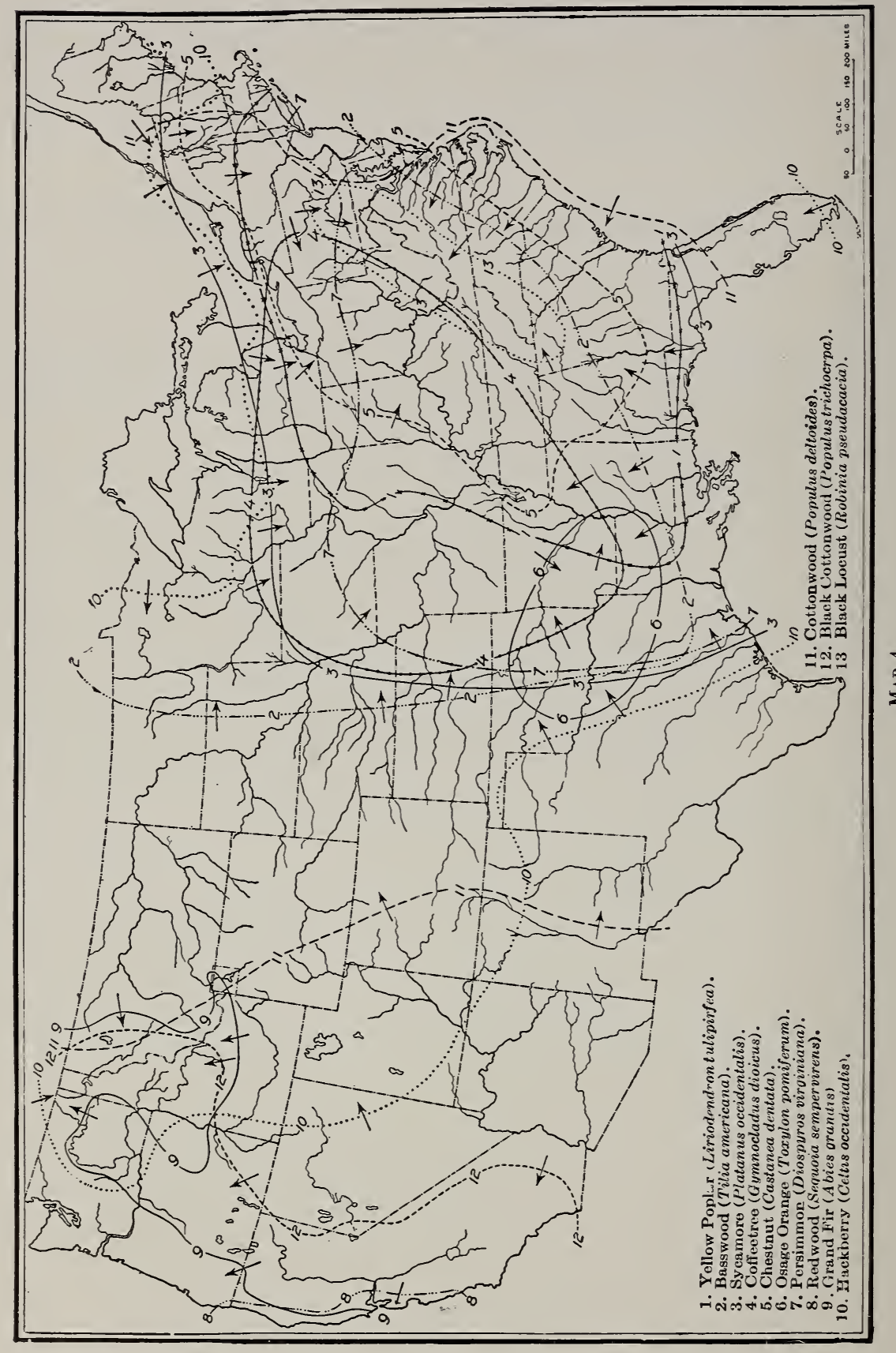


(cc) Fleartwood grayish brown. Tangential bands short and confined mostly to the outer portion of the summerwood (inconspicuous in black ash).

(a3) Sapwood narrow, rarely over three-fourt'is inch wide.

(a4) Annual rin's mostly wide, especially within the first few inches from the center. Pores containing flistening tyloses. Pith usually three-sided. Wood moderately light........................

(b4) Annual rings mostly narrow, eren near the center. Pores partly filled with tyloses, not glistening. Pith usually round. Wood moderately heavy...BLACK ASII, p. 47.

(b3) Sapwood over an inch, usually sereral inches wide. Wood heavy and hard...........................WHITE $\Lambda$ SH, p. 46.

GREEN ASH, p. 47.

(di) Heartwood brown with reddish tinge. Tangential bands long and rery conspicuous throughout the summerwood.

(a3) Sapwood very narrow. The porous ring of springwood from 2 to 4 pores wide. Inner bark slimy when chewed. Wood moderately heavy..................... SLIPPERY ELM, p. 42

(b3) Sapwood moderately wide, the porous ring of springwood only one pore wide except in very wide rings.

(a4) Wood heavy. Pores in springwood inconspicuous because comparatively small, not close together, and plugged with tyloses...................... (ORK ELM, p. 42.

(b4) Wood moderately heavy. Poresin springwood fairly conspicuous because larger than in rock elm, close torether and open......................WHITE ELM, p. 41.

3. Summerwood not figured with radial or tangential bands distinctly visible without a lens (fine tangential lines may be seen in hickory and persimmon with a hand $\mathrm{ens}$ ). See figure 5 .

A. Sapwood wide, orer 2 inches.

(a) Heartwood black, or brownish black (usually very small). Tangential surface marked with fine bands which run across the grain and are due to the storied arrangement of the rays. Wood very, very heavy.

PERSIMMON, p. 48 .

(b) Heartwood reddish brown. Tangential surface not marked with fine cross bands. Wood very heavy..................... The HICKORIES, p. 48.

BB. Sapwood narrow, rarely over three-fourths inch wide. Heartwood grayish brown.

Wood moderately heavy .................................

B. Diffuse-porous; that is, noring of large poresis formed at the beginning of each annual ring. See figure 6.

1. Individual pores plainly visible.

AA. Tangential surface marked with fine bands which run across the grain and are due to the storied arrangement of the rays. Heartwood black, or brownish black (usually very small). Sapwood wide. Wood very, very heavy and hard.

PERSIMMON, p. 48.

BB. Tangential surface not marked with fine cross bands.

(a) Heartwood reddish brown. Sapwood wide. Wood heavy.

WATER HICKORY, p. 49.

(b) Heartwood chocolate brown. Sapwood from moderate in width to narrow. Wood heavy and hard.......................BLACK WALNUT, p. 52.

(c) Heartwood light chestnut brown. Sapwood narrow. Wood moderately light and soft.............................. PUTTERNUT, p. 53.

2. Individual pores barely visible under conditions of good light and a very smoothly cut end surface.

A. Pores not crowded. Heartwood reddish brown. Wood heary.

(a) Inner bark with wintergreen flavor. Pith flecks very rare.

YELIOW BIRCH, p. 53 .

SWEET BIRCH, p. 54

(b) Inner bark without wintergreen lavor. Pith flecks usually abundant.

RIVER BIRCH, p. 54

BB. Pores crowded. Heartwood grayish. Wood light........COTTONWOOD, p. 55. 


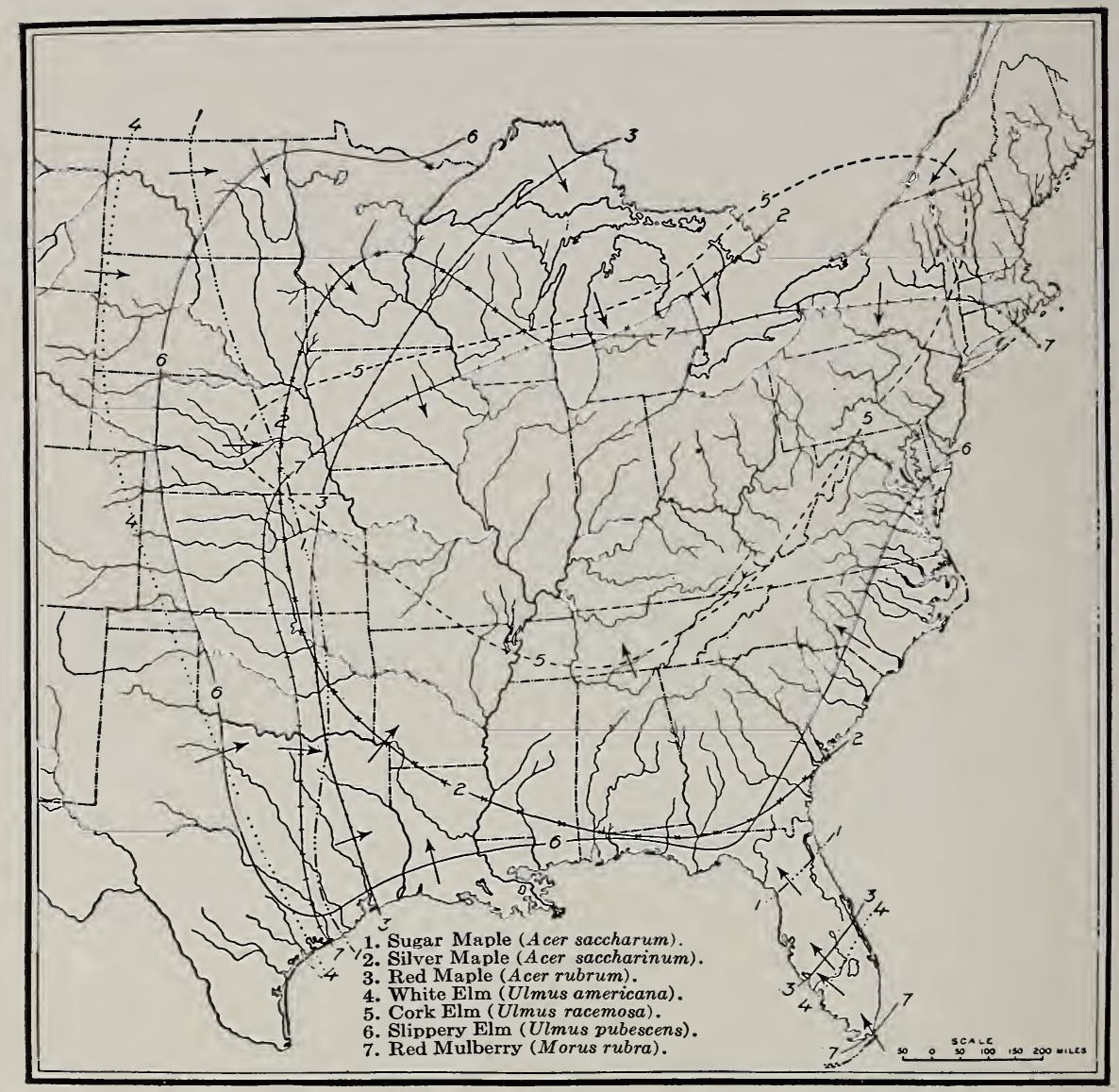

MAP 5. 
II. Pores not visible.

A. Rays comparatively broad and conspicuous. Color in various shades of light reddish brown.

1. The rays crowded. No denser and darker band of summerwood noticeable. Wood usually lock-grained; moderately heavy ............................SYCAMORE, p. 50.

2. The rays not crowded. A distinct, denser, and darker band of summerwood present. Wood usually fairly straight-grained; heavy........................ECH, p. 50.

B. Rays not conspicuous but distinctly visible.

1. Heartwood deep, rich, reddish brown. Sapwood narrow, usually less than one inch wide. Annual rings clearly defined. Rays very distinct. Wood moderately heavy.

BLACK CHERRY, p. 52.

2. Heartwood dingy, reddish brown, often with darker streaks. Sapwood moderately wide, usually over 1 inch. Annual rings not clearly defined. Rays relatively not very distinct. Wood moderately heavy................................ RED GUM p. 55.

3. Heartwood light reddish brown. Sapwood wide. Annual rings clearly defined by a thin, darker reddish brown layer. Rays very distinct.

AA. Wood heavy and hard; difficult to cut across the grain. Pith flecks very rare.

SUGAR MAPLE, p. 51

BB. Wood lighter and softer, rather easy to cut across the grain. Pith flecks often abundant.

SILVER MAPLE, p. 51

RED MAPLE, p. 52.

4. Heartwood light yellowish brown with greenish tinge. Sapwood usually over 1 inch wide. Annual rings clearly de.ined. Rays fairly distinct. Wood moderately light.

YELLOW POPLAR, p. 57.

5. Heartwood creamy brown with occasional darker streaks. Sapwood wide and not sharply defined from the heartwood. Rays fairly distinct. Wood light ...BASSWOOD, p. 58.

C. Rays not distinctly visible.

1. Annual rings not clearly divided into a band of soft springwood and denser and darker band of summerwood and, therefore, not conspicuous.

AA. The heartwood distinctly darker than the sapwood.

(a) Heartwood reddish brown. Wood straight-grained; heavy.

(aa) Inner bark with wintergreen flavor. Pith flecks rare.

YELLOW BIRCH, p. 53.

SWEET BIRCH, p. 54 .

(bb)Inner bark without wintergreen flavor. Pith flecks usually abund-

(b) Heartwood grayish brown. ant ....................................

(a) Wood cross-grained; moderately heavy.

$$
\begin{aligned}
& \text { BLACK GUM, p. } 56 . \\
& \text { COTTON GUM (TUPELO), p. } 57 .
\end{aligned}
$$

(bb) Wood fairly straight-grained; light...........COTTONWOOD, p. 55. AA. The heartwood not distinctly darker than the sapwood.

(a) Wood odorless and tasteless; light and soit. Color yellowish.

YELLOW BUCKEYE, p. 59.

\section{CONIFERS.}

OHIO BUCKEYE, p. 59 .

(b) Wood with spicy odor and taste; moderately light in weight. Color pale brown .............................PORT ORFORD CED $\Lambda$ R, p. 68

(c) Wood with resinous odor: heavy to very heavy. Color creamy brown.

PIÑON (PINE), p. 61.

2. Annual rings clearly divided into a band of soft springwood and a denser and darker band of summerwood. Although the summerwood may not be pronounced, yet the annual rings are always clearly de.ined by it.

AA. The heartwood distinctly darker than the sapwood.

(a) Wood "pitchy," as indicated by the resinous odor and by exudations of resin at the ends, especially from the sapwood, although on cuts made after the wood is seasoned the resin does not come out unless the wood is heated.

(aa) Heartwood creamy or orange-brown to reddish brown. Resin ducts abundant, visible as minute openings or, more often, as darker or lighter colored specks, or as brownish lines on longitudinal surfaces. Sapwood widely variable in width.......... The PINES, p. 59.

(a3) The summerwood inconspicuous and not much harder than the springwood.......................... The SO FT PINES:

(a4) Wood soft and moderately light; straight-grained. Annual rings of moderate width. Heartwood light reddish brown.............WESTERN WHITE PINE, p. 60。

LIMBER PINE, p. 61. 


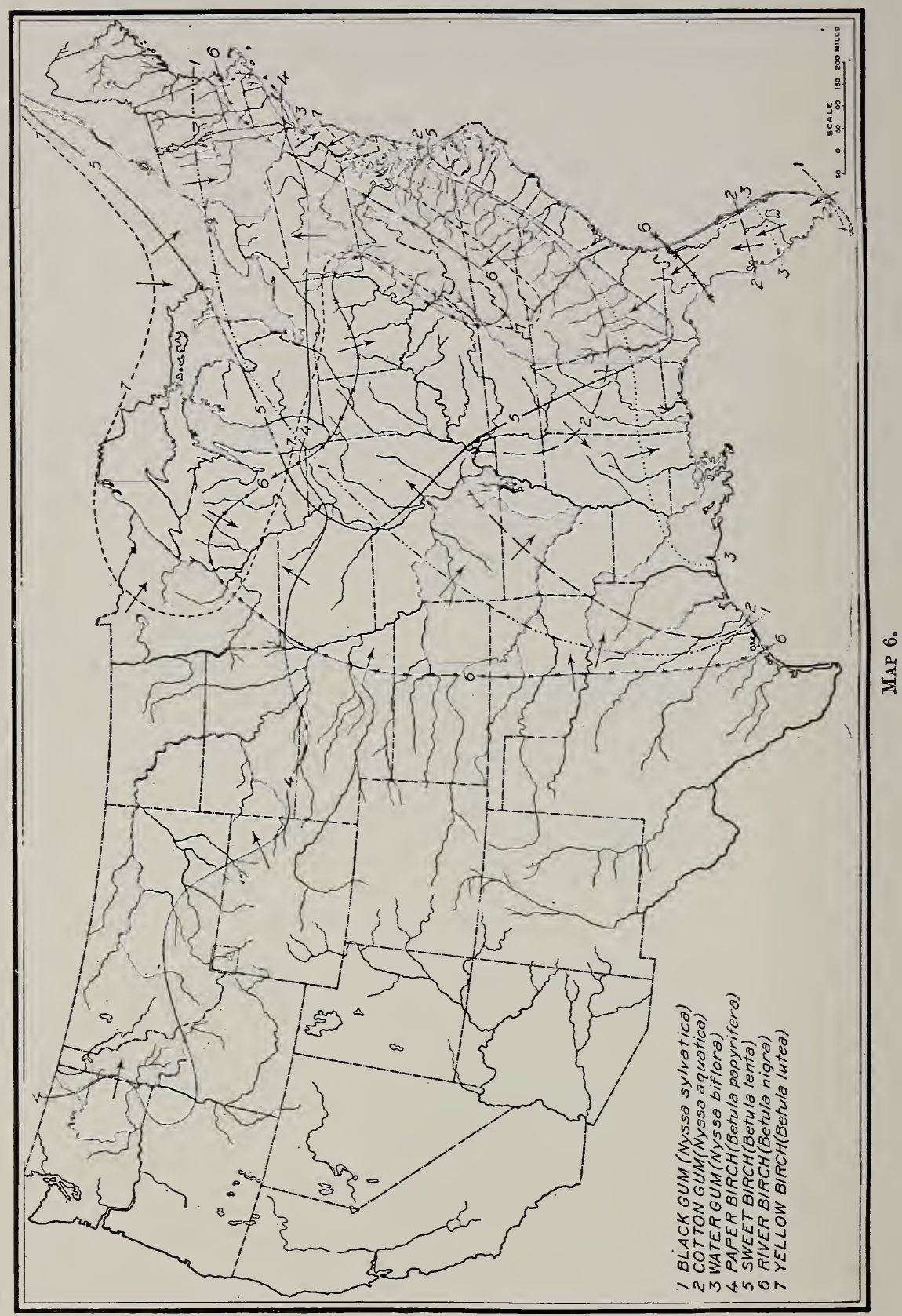


(b4) Wood hard and moderately heavy to very heavy, often cross-grained. Annual rings narrow.

(a5) Heartwood reddish brown. Tangential surface has numerous slight depressions which give it a dimpled appearance especially noticeable on split surfaces. BRISTLE-CONE PINE, p. 61.

(b5) Heartwood creamy brown. Tangential surface not dimpled. Wood sometimes very heavy.

PIÑON (PINE), p. 61.

(b3) The summerwood conspicuously darker and harder than the springwood. (This feature is not so noticeable in the sapwood of o!d trees as in the heartwood.)

(a5) Wood moderately light.

The HARD PINES:

WESTER N SPECIES:

(a6) The sapwood usually less than 2 inches wide (mostly about 1 inch). Tangential surface has numerous slight depressions which give it a dimpled appearance, especially noticeable on split surfaces. Openings of resin ducts not visible without a lens.

LODGEPOLE PINE, p. 62.

(b6) The sapwood usually over $2 \frac{1}{2}$ inches wide (mostly over 3 inches). Tangential surfaces rarely dimpled. Openings of resin ducts often visible without a lens.

WESTERN YELLOW PINE, p. 62.

(b5) Wood moderately heavy to very heavy. Heartwood orange brown to reddish brown.

$$
\begin{aligned}
& \text { EA S TER N SP ECIES: } \\
& \text { NORWAY PINE, p. } 63 . \\
& \text { PITCH PINE, p. } 64 . \\
& \text { SHORTLEAF PINE, p. } 64 . \\
& \text { LOBLOLLY PINE, p. } 64 . \\
& \text { POND PINE, p. } 65 . \\
& \text { LONGLEAF PINE, p. } 65 . \\
& \text { SLASH PINE, p. } 65 .
\end{aligned}
$$

(See discussion of the pines, page 59. For distinguishing longleaf from loblolly and shortleaf pine, see Appendix, p. 73.)

(bb) Heartwood orange-reddish to red. Resin ducts not abundant, occasionally visible as whitish specks in the summerwood. Sapwood usually over 1 inch wide. Wood moderately heary.

DOUGLAS FIR, p. 66 .

(cc) Heartwood russet brown. Resin ducts not abundant; usually not visible without a lens. Sapwood usually less than 1 inch wide. Wood moderately heavy.

(a3) Annual rings narrow

(b3) Annual rings moderately wide............. TAMARACK, p. 67

(a) Ieartwood deep reddish brown; without characteristic odor or taste. Annual rings regular in width and outline. Sapwood over 1 inch wide. Wood moderately light .................. RE DWOOD, p. 70.

(bb) Heartwood light brown to dark, dingy brown, with or without reddish tinge. Odor characteristic but not resinous or "pitchy."

(a3) Odor somewhat rancid; heartwood tasteless. Annual rings mostly irregular in width and outline. Sapwood usually over 1 inch wide. Color highly variable from pale brown with or without reddish tinge to blackish brown. Weight variable from moderately light to heavy. Longitudinal surfaces feel and appear waxy .................. BALD CYPRESS, p. 71 .

(b3) Odor aromatic (like cedar shingles); heartwood slightly bitter in taste. Annual rings narrow but regular in width. Sapwood rarely over 1 inch wide. Wood very light in weight. Longitudinal surfaces not appearing waxy.

(a4) Heartwood brown with reddish tinge.

WESTERN RED CEDAR, p. 71.

(b4) Heartwood brown, rarely with reddish tinge.

ARBORVIT AE (NORTHERN White Cedar), p. 72. 


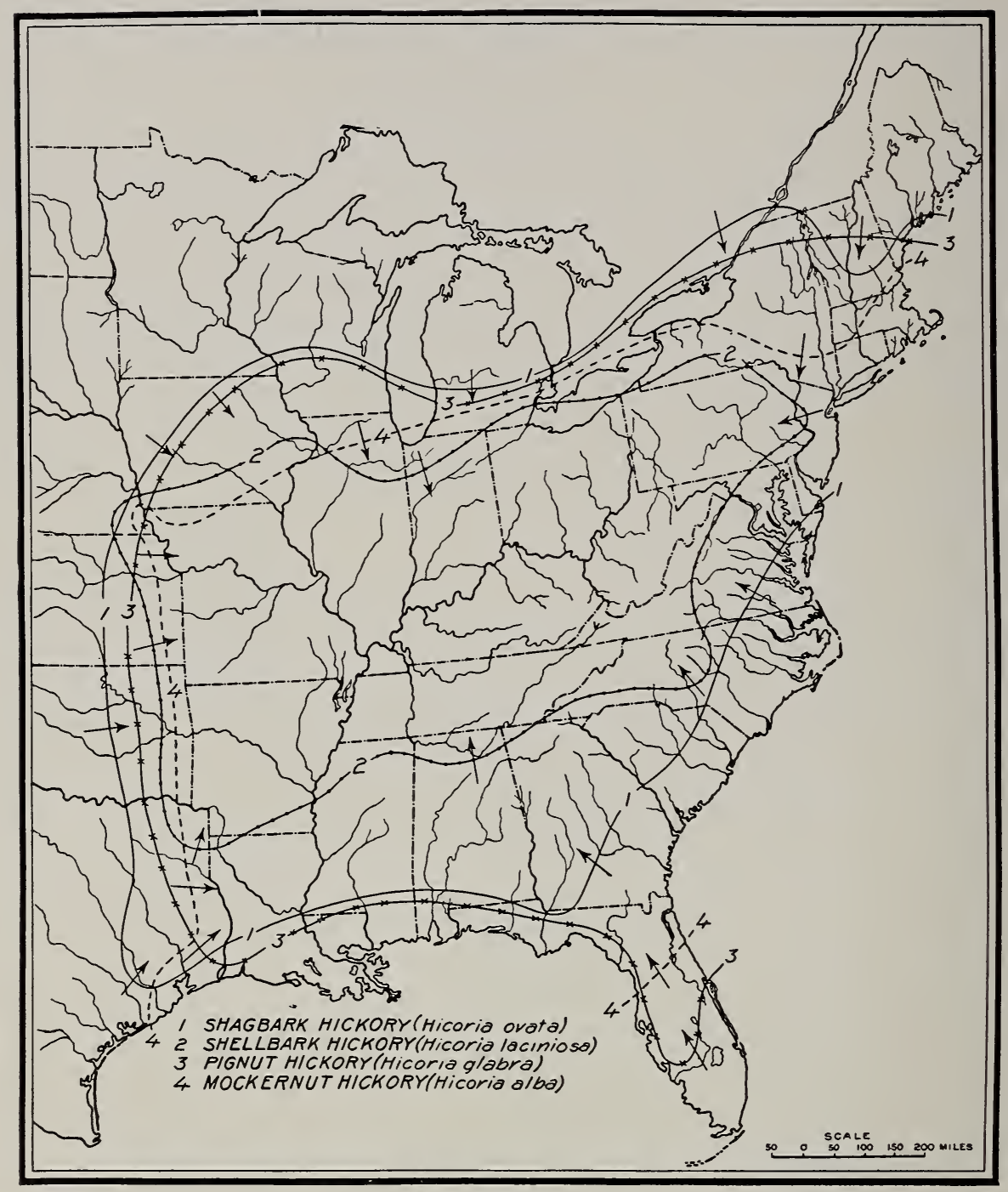

MAP 7. 
BB. The heartwood not distinctly darker than the sapwood.

(a) Wood resinous, as indicated by the odor or exudations of resin at the ends, especially from the sapwood.

(aa) Tangential surface has numerous slight depressions which give it a dimpled appearance, especially noticeable on sp'it surfaces. The heartwood sometimes slightly darker than the sapwood. Wood moderately heavy ......................LODGEPOLE PINE, p. 62.

(bb) Tangential surface not dimpled.

(a3) Color pale brown, almost white. Annual rings mostly moderately wide. Wood light in weight.ENGELMANN SPRUCE, p. 65.

(b3) Color creamy brown. Annual rings mostly narrow. Wood heavy to very heavy ................PIÑON (PINE), p. 61.

(b) Wood not resinous.

(a) Odor and taste spicy. Color pale brown. Wood moderately light. PORT ORFORD CEDAR, p. 68.

(bb) Odor and taste not spicy, although a characteristic odor may be noticeable.

(a3) Wood whitish, at least in the springwood; the summerwood may be dark reddish brown, especially in pieces of rapid growth, in which case there is a decided contrast between springwood and summerwood.

(a4) Freshly cut surface of dry wood has a mild, rank odor. Little contrast between springwood and summerwood. Growth rings of moderate width. Wood light.

ALPINE FIR, p. 69.

(b4) Freshly cut surface of dry wood does not have a rank odor; decided contrast between springwood and summerwood. Growth rings fairly wide. Wood moderately light. (a5) Outer bark contains whitish layers.

WHITE FIR, p. 68.

(b5) Outer bark contains thin, very dark reddish brown layers. .......................GRAND FIR, p. 69 .

(b3) Wood has reddish hue, the springwood as well as the summerwood being colored. Moderately light to moderately heavy. Fresh pieces have a sour odor.

(a4) Wood coarse and splintery, often cup-shaken.

EASTERN HEMLOCK, p. 69.

(b4) Wood not very coarse or splintery, usually not cup-shaken. WESTERN HEMLOCK, p. 70.

\section{KEY FOR THE IDENTIFICATION OF WOODS WITH THE AID OF A HAND LENS. ${ }^{1}$}

\section{HARDWOODS.}

I. Wood with pores. The pores are conspicuously larger than the surrounding cells, although in some species they are not visible without magnification. Neither the pores nor other cells are in continuous radial rows.

A. Ring-porous; that is, the pores at the beginning of each annual ring are comparatively large, forming a distinct porous ring, and decrease in size more or less abruptly toward the summer. wood. See figures 3,4 , and 5 .

1. Summerwood figured with wavy or branched radial bands. The bands visible without a lens on a smoothly cut surface. See figure 3.

AA. Many rays very broad and conspicuous. Wood heavy to very heavy.

The OAKS, p. 36 .

(a) Pores in the summerwood very small and so numerous as to be exceedingly difficult to count under a lens; pores in the springwood usually densely plugged with tyloses. Heartwood brown without reddish tinge.

The WHITE-OAK GROUP, p. 37.

(b) Pores in the summerwood larger, distinctly visible with (sometimes without) a hand lens and not so numerous but that they can readily be counted under a lens; pores in springwood mostly open, tyloses not abundant. Heartwood brown, with reddish tinge especially in vicinity of knots.

The RED-OAK GROUP, p. 39.

1 Unless it is otherwise directed, all observations as to structure should be made on the end surface of rings of average width cut smoothly with a very sharp knife; and all observations as to color should be made on a freshly cut longitudinal surface of the heartwood. 


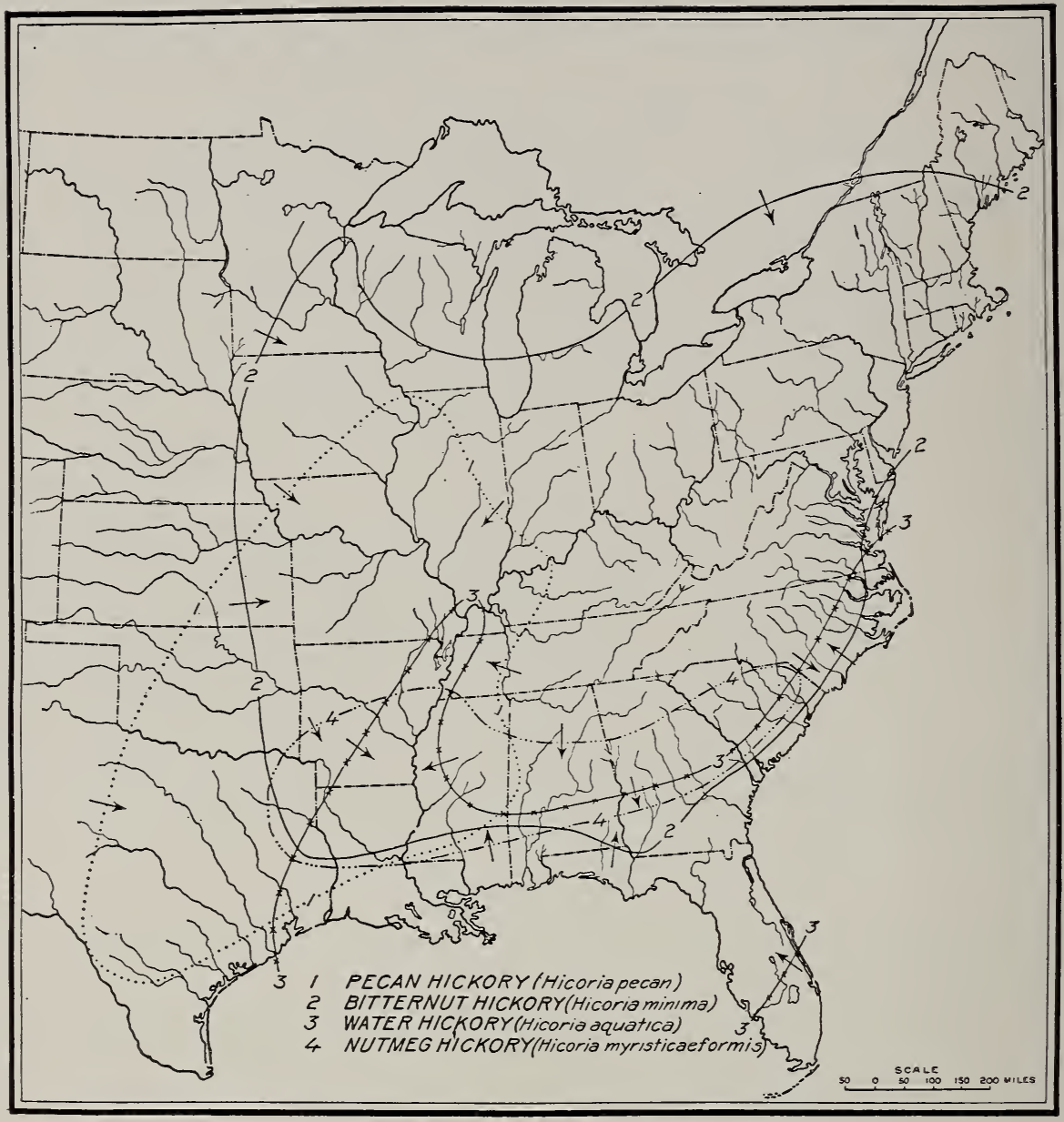

Map 8. 
BB. All rays very fine and inconspicuous. Color grayish brown. Wood moderately light................................................ 41.

2. Summerwood figured with long or short wavy tangential bands which include the pores. The bands visible without a lens on a smoothly cut end surface. See figure 4 .

AA. Careful examination with a hand lens shows the pores of the summerwood to be joined in more or less continuous bands, and the bands to be evenly distributed throughout the summerwood.

(a) Sapwood moderate in width or narrow, mostly less than 3 inches; heartwood distinct, light to ceep reddish brown. Rays not distinct without a lens.

The ELMS:

(aa) Large pores in the springwood usually in one row except in very wide rings.

(a3) Rows of pores in the springwood conspicuous because the pores are large enough to be plainly visible without a lens; they are mostly open, containing only a few tyloses; and they are fairly close together. Sapwood from 1 to 3 inches wide. Wood morlerately heavy; fairly easy to cut......... WHITE ELM, p. 41.

(b3) Rows of pores in the springwood inconspicuous because the pores are small, being barely visicle without a lens; they are mostly closed with tyloses, especially in the heartwood; and they are often somewhat separated. Sapwood from $3 / 4$ of an inch to $1 \frac{1}{2}$ inches wide. Wood heavy and difficult to cut.................................. CORK ELM, p. 42

(bb) Large pores in springwood in several rows; mostly open, containing few tyloses. Sapwood usually less than 1 inch wide, often only $\frac{1}{2}$ inch wide. Wood moderately heavy. Inner bark mucilaginous when chewed...................... SLIPPERY ELM, p. 42.

(b) Sapwood wide, over 3 inches, heartwood indistinct, yellowish or greenish gray. Pores in springwood mostly open, in several rows except in occasional narrow rings where they may form only one row. Rays distinct without a lens. Wood moderately heavy..................... IACKBERRY, p. 43. SUGARBERRY, p. 43.

BB. Careful examination with a hand lens shows the pores of the summerwood to be joined in more or less interrupted bands or in rounded groups of from 3 to 20 (especially in mulberry and coffeetree), the groups so arranged as to form tangential bands. In either case the bands are more pronounced in the outer portion of the summerwood than in the middle of the annual ring, where the pores are often isolated or in rounded groups.

(a) Large pores in the springwood containing numerous tyloses. Sapwood narrow, usually less than 1 inch wide.

(aa) Wood very, very heavy and exceedingly hard to cut across the grain. Rays not very distinct without a lens.

(a3) Heartwood golden brown with reddish brown streaks: coloriñ. matter readily soluble in cold water.. OSAGE ORANGE, p. 43.

(b3) Heartwood russet brown; coloring matter not readily soluble in cold water........................ BLACK LOCUST, p. 44.

(bb) Wood heavy, but lighter than the above and fairly easy to cut across the grain. Color russet brown. Rays very distinct without a lens.

RED MULBERRY, p. 44

(cc) Wood moderately light and easy to cut across the grain. Color grayish brown. Rays not distinct without a lens.

HARDY CATALPA, p. 45.

(b) Large pores in the springwood open, containing no tyloses but occasionally a bright-red gum. Heartwood cherry-red to reddish brown. Wood very heavy.

(aa) Pores in the outer portion of the summerwood mostly joined into bands, the individual pores of which are not distinctly visible with a lens magnifying 15 diameters. Rays mostly very distinct. Pith small, usually under 0.15 inch. Sapwood from $\frac{3}{4}$ of an inch to 2 inches wide on ties...........................HONEY LOCUST, p. 45.

(bb) Pores in the outer portion of the summerwood only occasionally joined Into bands, the individual pores being distinctly visible with an ordinary hand lens. Rays of uniform width, inconspicuous. Pith large, usually over 0.2 inch. Sapwood from $\frac{1}{2}$ inch to 1 inch wide on ties. COFFEETREE, p. 46. 


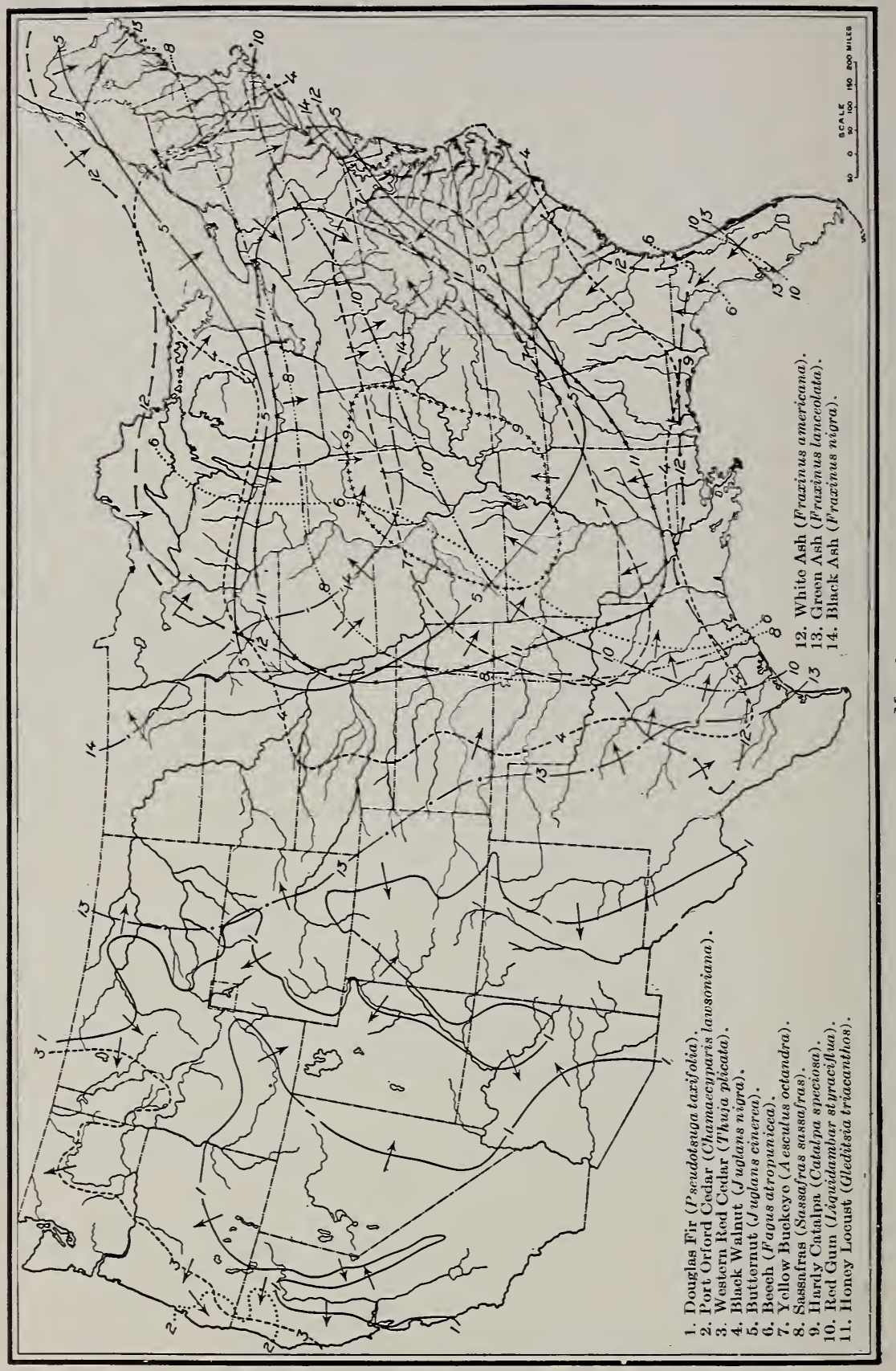


CC. Careful examination with a hand lens shows the pores of the summerwood to be isolated or in radial rows of 2 or 3 , but surrounded by parenchyma in such a manner as to appear in wavy tangential bands usually more distinct without a lens than with a lens.

(a) Parenchyma projecting tangentially from the pores in comparatively long lines often joining pores widely separated. Sapwood several inches wide; heartwood grayish brown, occasionally with reddish tinge. Wood heavy and hard ............................................

GREEN $\Lambda$ SH, p. 47.

(b) Parenchyma not projecting tangentially from the pores or only slightly so. Sapwood less than 1 inch wide; heartwood silvery brown. Wood moderately heavy.

(aa) Rays fine but distinct without a lens; wood has a spicy odor and taste. SASSAFRAS p. 47.

(bb) Rays not visible without a lens; wood does not have a spicy odor and taste..................................

3. Summerwood figured with numerous fine, light-colored tangential lires (parenchyma) which do not embrace the pores. Pores in the summerwood not much smaller than those in the springwood, usually visible without a lens. (Water hickory and persimmon are also classed as diffuse-porous woods.) Wood very heavy to very, very heavy.

AA. Lines of parenchyma inconspicuous even under a lens. Rays in tiers, appearing on tangential surface as fine bands running across the grain. Heartwood black, or brownish black..................................... PERSIMMON, p. 48 .

BB. Lines of parenchyma conspicuous under a lens, barely visible without a lens. Rays on tangential surface not in tiers; heartwood reddish brown.

The HICKORIES, p. 48.

4. Summerwood not figured with radial or tangential bands. Pores in summerwood very small, not visible without a lens, isloated, or it radial rows of two or three. Sapwood very narrow, heartwood silvery or grayish brown. Wood moderatcly heavy.

BLACK ASH, p. 47.

B. Diffuse-porous; that is, the pores are of about uniform size and evenly distributed throughout the annual ring, or if they are slightly larger and more numerous in the springwood, they gradually decrease in size and number toward the outer edge of the ring. See figure 6.

1. Rays comparatively broad and conspicuous, the widest ones fully two times as wide as the largest pores, appearing on the radial surface as distinct "flakes" or "silver grain" similar to quartered oak, but finer. Color in various shades of light reddish brown.

AA. Practically all rays broad. Pores crowded, decreasing little, if any, in size at extreme outer edge of the annual ring. Wood usually lock-grained, moderately heavy............................................ SYCAMORE, p. 50.

BB. Only part of the rays broad, the others narrower than the largest pores. Pores crowded in the springwood, decreasing in size and number toward the outer edge of the annual ring, thereby giving rise to a harder and darker band of summerwood. Wood usually fairly straight-grained; heavy...............BEECII, p. 50 .

2. Rays narrower, but very distinct without a lens, the widest ones of about the same width as the largest pores.

AA. Color light brown with reddish tinge. Springwood and summerwood of uniform density. Sapwood wide.

(a) Wood heavy, difficult to cut across the grain. Only part of the rays broad, the others very fine, scarcely visible with a lens. Pith flecks rarely present.

SUGAR MAPLE, p. 51.

(b) Wood moderately heavy, fairly easy to cut across the grain. Practically all the rays broad but not so broad as in sugar maple, therefore not so prominent but giving the appearance of being more numerous. Pith flecks common.

SILVER MAPLE, p. 51. RED MAPLE, p. 52.

BB. Color deep reddish brown. Springwood slightly more porous than summerwood. Sapwood narrow. Pith flecks common. Wood moderately heavy.

BLACK CHERRY, p. 52 。

3. Rays comparatively fine, narrower than the largest pores.

AA. Pores visible without a lens.

(a) Pores comparatively large and conspicuous without a lens, decreasing in size toward the outer limit of each annual ring; not crowded. Fine tangential lines of parenchyma often visible between the pores.

(a) Sapwood wide, usually over 3 inches in ties. (Pores often in a more or less well-defined zone in the springwood, therefore also classed as ring-porous woods.)

(a3) Heartwood black or brownish black. Rays in tiers, appearing on the tangential surface as fine bands running across the grain. Wood very, very heavy ................. PERSIMMON, p. 48.

(b3) Heartwood reddish brown. Rays not in tiers. Wood heavy. 


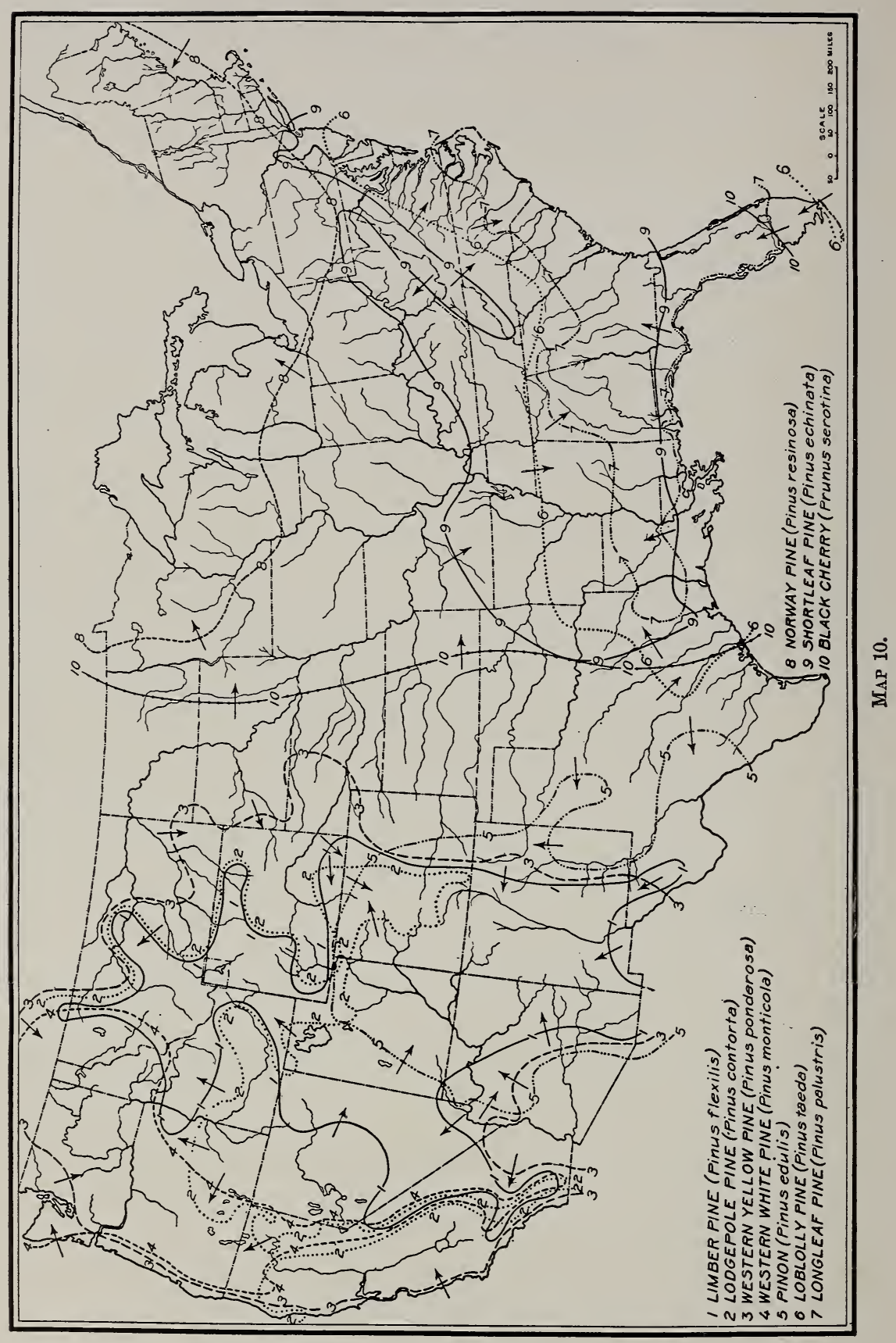


(bb) Sapwood narrow, mostly under 2 inches in ties; white or discolored; heartwood brown.

(a3) Wood heavy and hard. IIeartwood chocolate brown.

BLACK WALNUT, p. 52.

(b3) Wood moderately light and soft. IIeartwood light chestnut brown............................ BUTTERNUT, p. 53.

(b) Pores smaller, but on careful examination still clearly visible without a lens, at least in the springwood.

(aа) Pores not crowded, decreasing little, if any, in size toward the outer limit of the annual ring. Iays distinct under a lens. Ileartwood pale to moderately deep reddish brown. Wood heavy.

(a3) Pith flecks rare. Inner bark has a wintergreen flavor.

YELLOW BIRCH, p. 53 . SWEET BIRCH, p. 54.

(J3) Pith flecks abundant. Inner bark does not have a wintergreen flavor.............................RIVER BIRCII, p. 54

(bb) Pores crowded, decreasing somewhat in size and number toward the outer limit of each annual ring. Rays very fine, barely visible with a lens. Pith flecks occasionally present but not abundant. Wood light and soft. Color white to light grayish brown.

COTTONWOOD, p. 55

BB. Pores not visible without a lens.

(a) Pores appearing comparatively large and conspicuous under a lens.

(aa) Pores not crowded, decreasing little, if any, in size toward the outer limit of the annual ring. Rays distinct under a lens. Ileartwood pale to moderately deep reddish brown. Wood heavy.

(a3) Pith flecks rare. Inner bark has a wintergreen flavor.

YELLOW BIRCH, p. 53. SWEET BIRCH, p. 54.

(b3) Pith flecks abundant. Inner bark does not have a wintergreen flavor.

RIVER BIRCH, p. 54 .

$(\mathrm{bb})$ Pores crowded, decreasing somewhat in size and number toward the outer limit of each annual ring. Rays very fine, barely visible with a lens. Pith flecks occasionally present but not abundant. Wood light and soft. Color white to light grayish brown.

COTTONWGOD, p. 55

(b) Pores appearing comparatively small under a lens.

(aa) Heartwood pale reddish brown. Rays very distinct without a lens. Pores not very crowded. Wood moderately heavy.

SILVER MAPLE, p. 51 RED MAPLE, p. 52 .

(bb) Heartwood dingy, reddish brown. Rays relatively not very distinct without a lens. Pores crowded. Wood moderately heavy.

RED GUM, p. 55 .

(cc) Heartwood brownish gray. Rays not distinct without a lens. Wood moderately heavy.

(a3) Pores very small, only occasionally in radial rows of from 3 to 6.

BLACK GUM, p. 56.

(b3) Pores slightly larger, often in radial rows of from 3 to 6 . (These distinctions between black gum and cettcn gum can be applied only by comparison with a piece of wood known to be one species or the other .......... COTTON GUM (TUPELO), p. 57 ,

(dd) Heartwood yellowish brown with greenish tinge. Rays distinct without a lens. Wood moderately light... YLLLOW POPLAR, p. 57.

(ee) Heartwood creamy brown. Rays distinct without a lens; not in tiers. Wood light............................. BASSWOOD, p. 58

(II) IIeartwood creamy white. Pores very minute. Rays very fine barely distinct with a lens; arranged in tiers, producing very fine bands running across the tangential surface. Wood light.

YELLOW BUCKEYE, p. 53 . OIIIO BUCKEYE, p. 59. 


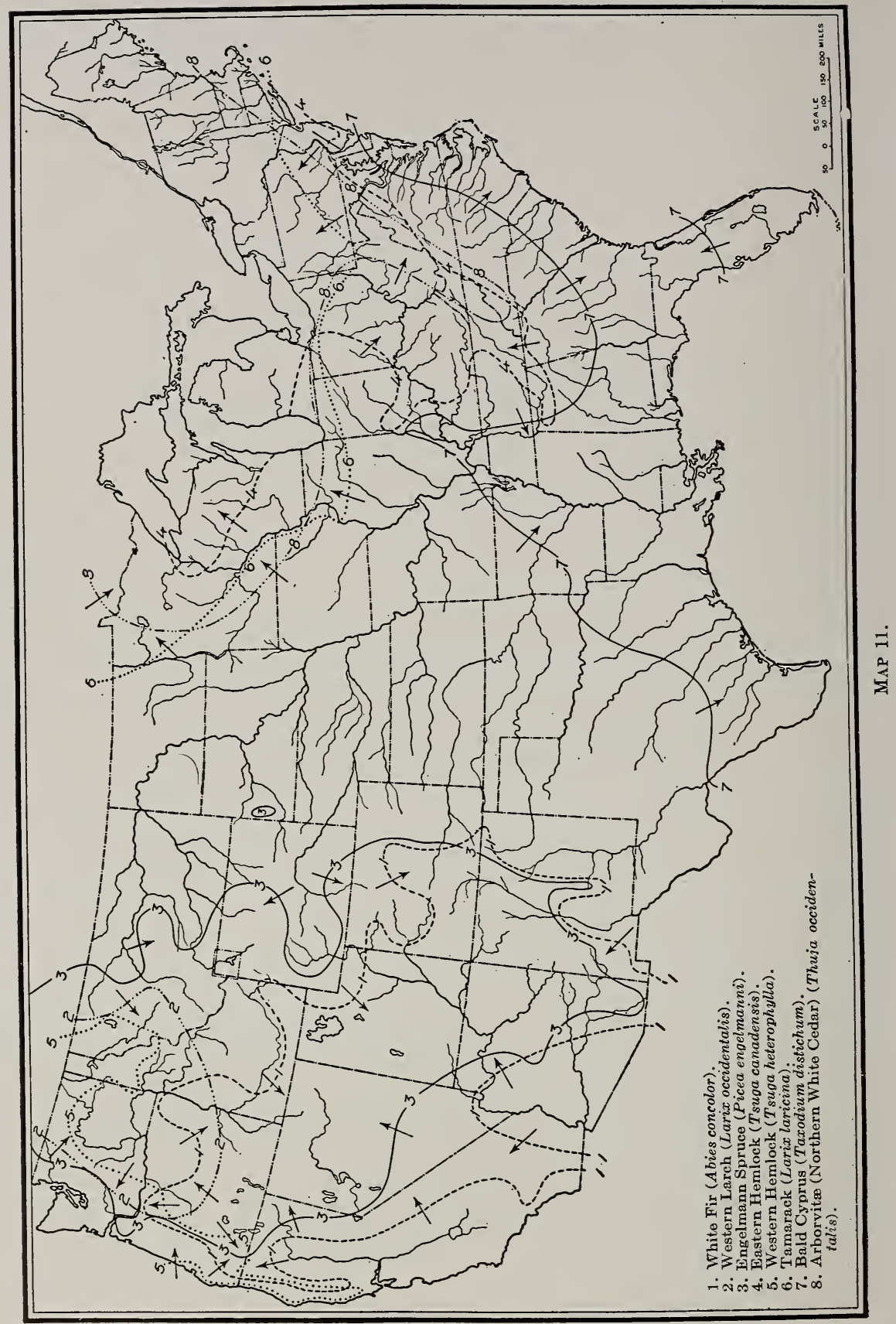




\section{CONIFERS.}

II. Wood without pores. The cells (tracheids) very small, barely visible with a lens; practically uniform in size, except in the summerwood, where they are narrower radially; and arranged in definite radial rows. Rays very fine.

A. Resin ducts present but often not distinct without a lens. (Exudations of resin over the end surface is a positive indication of the presence of resin ducts.)

1. Resin ducts numerous; scattered singly; conspicuous under a lens and usually visible without a lens as minute openings, or more often as darker or lighter colored specks, or as brownish lines on longitudinal surfaces........................... The PINES, p. 59. AA. Summerwood inconspicuous and not perceptibly harder than the spring wood.

The SOFT PINES:

(a) Wood soft and moderately light; straight-grained. Annual rings of moderate width. Heartwood light reddish brown.

WESTERN WHITE PINE, p. 60. LIMBER PINE, p. 61.

(b) Wood hard and moderately heavy to very heavy; often cross-grained. Annual rings narrow.

(aa) Heartwood reddish brown. Tangential surface has numerous slight depressions which give it a dimpled appearance, especially noticeable on split surfaces.................. BRISTLE-CONE PINE, p. 61.

(bb) Heartwood creamy brown. Tangential surface not dimpled. IWood sometimes very heavy................... PIÑON (PINE), p. 61.

BB. The summerwood conspicuously darker and harder than the springwood. (This feature is not so noticeable in the sapwood of old trees as in the heartwood, where the annual rings are wider)....................... The HARD PINES:

(a) Wood moderately light..................... WES TER N SPECIES:

(aa) The sapwood usually less than 2 inches wide (mostly about 1 inch). Tangential surface has numerous slight depressions which give it a dimpled appearance, especially noticeable on split surfaces. Resin ducts small, not visible without a lens..LODGEPOLE PINE, p. 62.

(bb) The sapwood usually over $2 \frac{1}{2}$ inches wide (mostly over 3 inches). Tangential surface rarely dimpled. Resin ducts comparatively large, usually visible without a lens.

WESTERN YELLOW PINE, p. 62.

(b) Wood moderately heavy to very heavy. Heartwood orange-brown to reddish brown.

EASTER N SPECIES:

NORWAY PINE, p. 63.

PITCH PINE, p. 64.

SHORTLEAF PINE, p. 64.

LOBLOLLY PINE, p. 64.

POND PINE, p. 65.

LONGLEAF PINE, p. 65.

SLASH PINE, p. 65.

See discussion of the pines, p. 59. (For distinguishing longleaf from loblolly and shortleaf pine, see Appendix, p. 73.)

2. Resin ducts not numerous; scattered singly or in tangential groups of from 2 to 20 ; not visible without a lens, or appearing as whitish specks in the summerwood.

A 1 . The heartwood of the same color as the sapwood, or slightly darker, usually not clearly defined. Wood light................ ENGELMANN SPRUCE, p. 65.

BB. The heartwood decidedly darker than the sapwood. Wood moderately heavy.

(a) Heartwood orange-reddish to red. Sapwood over one inch wide.

DOUGLAS FIR, p. 66.

(b) Heartwood russet brown. Sapwood usually less than one inch wide.

(aa) Annual rings narrow................ WESTERN LARCH, p. 67. (bb) Annual rings moderately wide................ TAMARACK, p. 67.

B. Resin ducts normally absent.

1. The heartwood of about the same color as the sapwood, distinction not clear.

A. Wood has a spicy odor and taste; moderately light. Summerwood inconspicuous. Color pale brown........................ PORT ORFORD CEDAR, p. 68.

BB. Wood does not have a spicy odor or taste, although other characteristic odor may be present.

(a) Wood whitish, at least in the springwood; the summerwood may be dark reddish brown, especially in pieces of rapid growth, and in that case forms a decided contrast between the springwood and summerwood.

(aa) Freshly cut surface of dry wood has a rank odor. Little contrast between springwood and summerwood. Rings of moderare width. Wood light...............................ALPINE FIR, p. 69. 
(bb) Freshly cut surface of dry wood does not have a rank odor. Decided contrast between springwood and summerwood. Rings usually fairly wide. Wood moderately light.

(a3) Outer bark containing whitish layers........WHITE FIR, p. $f .8$.

(b3) Outer bark containing thin, very dark reddish-brown layers.

GRAND FIR, p. 69.

(b) Wood has a reddish hue, even the springwood has a pale reddish color; thus making the contrast between the springwood and summerwood less pronounced; odor somewhat sour in fresh wood. Wood moderately light to moderately heavy.

(aa) Wood coarse and splintery, often cup-shaken. Abnormal resin passages not present.......................EASTERN HEMLOCK, p. 69.

(bb) Wood not very coarse or splintery, usually not subject to cup-shake. A hnormal resin passages occasionally present in tangential rows in the outer portion of the summerwood.

2. The heartwood distinctly darker than the sapwood

WESTERN HEMLOCK, p. 70.

AA. Heartwood deep reddish brown. Annual rings regular in width and outline. Sapwood over 1 inch wide. Wood odorless and tasteless; moderately light. REDWOOD, p. 70.

BB. Heartwood light brown to dingy brown with or without reddish tinge. Odor distinct when fresh surfaces are exposed.

(a) Odor somewhat rancid; heartwood tasteless. Annual rings mostly irregular in width and outline. Sapwood usually over 1 inch wide. Color highly variable from pale brown with or without reddish tinge to blackish brown. Weight variable from muderately light to heavy. Longitudinal surfaces feel and appear waxy...........................

(b) Odor aromatic (like cedar shingles); heartwood slightly bitter in taste. Annual rings narrow but regular in width. Sapwood rarely over 1 inch wide. Wood very light in weight. Longitudinal surfaces not appearing waxy.

(aa) Heartwood brown with reddish tinge.

WESTERN RED CEDAR, p. 71. (bb) Heartwood brown, rarely with reddish tinge.

ARBORVIT E (NORTHERN WHITE CEDAR), p. 72 .

\section{DESCRIPTION OF HARDWOODS.}

\section{THE OAKS.}

Nearly half of the ties used in this country are oak. There are about 58 species of oak native to the United States, but some are too scrubby to be of any commercial use and others are used only locally. About 20 different species are used for ties to a commercial extent. No effort is made, however, to market each species under its own name. The oaks used for ties are commonly divided into two groups, the white oaks and the red oaks, but rarely is any classification as to species attempted. The white oaks are more durable than the red oaks. In strength far more variation has been found in individual pieces of the same species than in arerages of different species or even in averages of the two groups.

The woods of the species belonging to each group are so much alike that, with few exceptions, they are not readily distinguishable. However, the wood structure of the two groups is distinctly different and indicates clearly whether a piece of oak belongs to the red-oak group or to the white-oak group. An inspector can usually determine the group to which a tie belongs by the color and general appearance of the grain, but in case of doubt the character of the pores in the summerwood forms the only definite means of classification. 


\section{HOW TO DISTINGUISH WOODS OF THE WHITE-OAK GROUP FROM WOODS OF THE RED-OAK GROUP.}

Cut smoothly with a sharp knife a small area about one-fourth to one-half inch square on the end surface of the oak wood in question. The area should be so selected as to include rings of average width. Examine the surface with a hand lens and note especially the small pores in the summerwood. If these pores appear very distinct and are not too numerous to be counted, the specimen belongs to the redoak group. See illustration of red oak, Pl. V, fig. 1; black oak, Pl. IV, fig. 1 ; pin oak, Pl. IV, fig. 2 ; and willow oak, Pl. V, fig.1. If the pores are very small and somewhat indistinct even under a lens and so numerous as to make it exceedingly difficult to count them, the specimen belorgs to the white-oak group. See illustration of white oak, Pl. II, fig. 1; chestnut oak, Pl. II, fig. 2, and post oak, Pl. III, fig. 1.

The large pores in the springwood of the white oaks are usually densely plugged with tyloses, and those of the red oaks are more open; but this feature is not so reliable for classification as the character of the pores in the summerwood.

\section{THE WHITE-OAK GROUP.}

The following features are characteristic of the wood of all species of the white-oak group:

Pores.-In the springwood, large and easily visible to the unaided eye, forming a porous ring one or two rows, and in broad rings three rows, of pores wide. The pores decrease in size more or less abruptly toward the summerwood, where they are grouped in $\mathrm{V}$-shaped radial bands. In the summerwood they are somewhat angular and so small and numerous that it is exceedingly difficult to count them even with the aid of a good hand lens.

The large pores in the springwood are usually plugged with tyloses (see Plate I), except in the outer portion of the sapwood. In chestnut oak the pores are more open, in this respect resembling those in the red oaks.

Rays.-Some of the rays are very broad and conspicuous and from one-half inch to 4 inches high (i. e., measured with the grain), while others are so fine as to be barely visible with a lens. The broad rays appear as conspicuous streaks where the bark has been removed.

Parenchyma.-Plainly visible with a lens as light-colored tangential lines and also as a lighter colored area surrounding the pores of the summerwood.

Annual rings.-Mostly from moderately wide to narrow; occasionally wide.

Sapwood.-From 1 to several inches in thickness, often discolored by tannin and other material leached out of the bark.

Heartwood.-Grayish brown, usually without reddish tinge.

Physical properties.-The wood is heavy but varies considerably in weight. It is usually straight-grained and checks easily on drying. When dry the wood is without characteristic odor and taste.

Similar Woods.

Because of the broad rays the woods of the white-oak group are not easily confused with any other woods excepting those of the red-oak group. For a method of distinguishing these two groups see above and study the illustrations in Plates II, III, IV, and V.

Some of the southeru white oaks grow rapidly and have wide annual rings, so that they appear different on the end surface from those of slower growth. In examining the summerwood pores of such oaks an effort should be made to locate annual rings of moderate width, which can often be found near the bark. 


\section{WHITE OAK.}

\section{Other Names.}

Quercus alba Linn.

The true white oak is the most important tree of the white-oak group. Throughout its range it is known as white oak, although in Arkansas it is also named stave oak because it is cut in large quantities for tight cooperage.

Geographic Distribution.

See map, page 14.

Distinguishing Characteristics.

Since no reliable method has yet been found for distinguishing true white-oak ties from post oak, swamp white oak, cow oak, and others of the white oak group, all these species are described collectively on page 37 .

\section{CHESTNUT OAK.}

Other names.

\section{Quercus prinus Linn.}

Rock chestnut oak; rock oak; tanbark oak.

Geographic Distribution.

See map, page 14.

Distinguishing Characteristics.

(See white-oak group, p. 37.)

Chestnut oak differs from the other white oaks in not having the pores in the heart wood densely plugged with tyloses. Occasional closed or partly closed pores may be found, but in general the pores are more open, as in the red oaks.

Discoloration of the sapwood due to the tannin being leached out of the bark is common in chestnut oak, but is not always reliable for identification.

\section{POST OAK.}

Other Names.

\section{Quercus minor (Marsh.) Sargent.}

Iron oak; box white oak; white oak. The name post oak is derived from the abundant use of this species for posts in the northern portion of its range where the tree is comparatively small.

Geographic Distribution.

See map, page 14.

Distinguishing Characteristics.

(See white-oak group, p. 37.)

No reliable means of readily distinguishing this wood from all other white oaks is known.

\section{OTHER WHITE OAKS USED FOR TIES AND TIMBERS.}

Cow оAK (Quercus michauxii Nutt.), also known as basket oak, swamp white oak (Del., Ala.), and swamp chestnut oak (Fla.). For geographic distribution, see map, page 16.

OVERCUP OAK (Quercus lyrata Walt.), also known as swamp post oak, water white oak, and swamp white oak (Tex.). For geographic distribution, see map, page 16.

BUR OAK (Quercus macrocarpa Michx.), also known as mossycup oak, overcup oak, blue oak, scrub oak, overcup white oak (Vt.), and mossycup white oak (Minn.). For geographic distribution, see map, page 14.

Swamp whIte oAK (Quercus platanoides (Lam.) Sudworth) or swamp oak. For geographic distribution, see map, page 16.

CHINQUAPIN OAK (Quercus acuminata (Michx.) Houba), also known as chestnut oak, yellow oak, shrub oak, dwarf chestnut oak, shrub oak (Nebr.), white oak (Tenn.), and rock oak (Ark.). For geographic distribution, see map, page 16. 
THE RED-OAK GROUP.

The following features are characteristic of the wood of all species of the red-oak group:

Pores.-In the springwood, large and easily visible without a lens, forming a porous ring from two to three rows, or in very wide rings, four rows of pores wide. They decrease in size more or less abruptly or in wide rings somewhat gradually, toward the summerwood, where they are grouped in radial bands often branching or widening toward the outer limit of the annual ring. The pores in the summerwood are well rounded and very distinct under a lens and occasionally barely visible even without a lens. They are not too numerous or crowded to be easily counted with the aid of a magnifying glass.

The large pores in the springwood are open for the most part, although occasionally tyloses are present in the pores, notably in blackjack, in which they are almost as abundant as in the white-oak group.

Rays.- Some of the rays are very broad and conspicuous; others are so fine as to be barely visible with a lens and are easily overlooked. The large rays range from one-fourth to one inch, or occasionally more, in height (i. e., measured with the grain), averaging somewhat less than in the white oaks. They appear as conspicuous darker streaks where the bark has been removed.

Parenchyma.-Plainly visible as light-colored tangential lines in the summerwood and as a lighter area surrounding the smaller pores.

Annual rings. - Mostly from moderate in width to wide.

Sapwood.-Highly variable in thickness, from 1 to 3 inches.

Heartwood.-Mostly brown with reddish tinge, especially in the vicinity of knots. Exceptional pieces resembling white oak in color may be found.

Physical properties.-The wood of the various species of the red-oak group is heavy, but varies considerably in weight, the variation depending more on the conditions under which the tree grew than on the species. It is usually straight-grained and is subject to considerable checking in seasoning.

Similar Woods.

The red oaks resemble the white oaks in being heavy and in having broad rays, but the characteristic reddish tinge and open pores of the red-oak woods are usually sufficiently pronounced to distinguish them from the woods of the white-oak group. In case of doubt as to which group a piece of oak belongs to, examine the pores in the summerwood as directed on page 37 .

RED OAK.

Other Names.

Quercus rubra Linn.

The true red oak, like the true white oak, is rarely known by any other name. Occasionally it is called black oak or Spanish oak.

Geographic Distribution.

See map, page 18.

Distinguishing Characteristics.

Red-oak wood can not be distinguished from most of the other oaks be!onging to the same group.

Other Names.

YELLOW OAK.

Quercus velutina Lam.

Black oak; quercitron oak; tanbark oak (Ill.); yellow-barked oak (Minn.); spotted oak (Mo.); dyer's oak (Tex.).

Geographic Distribution.

See map, page 18. 
Distinguishing Characteristics.

The yellowish inner bark, part of which may nearly always be found on ties even when peeled, is sufficient to distinguish yellow oak from all other oaks. Yellow-oak ties or timbers sawed or hewn on all sides can not be distinguished from other red oaks.

\section{PIN OAK.}

\section{Other Names.}

\section{Quercus palustris Muenchh.}

Swamp Spanish oak; water oak; water Spanish oak (Ark.). Pin oak is so called because of the numerous small branches scattered along the trunk, appearing like so many pins promiscuously inserted. These branches leave their corresponding "pin" knots in the wood, thus suggesting another origin of the common name.

Geographic Distribution.

See map, page 18.

Distinguishing Characteristics.

The numerous knots in pin-oak ties afford a rough but not absolutely reliable means of identification; for any oak that might accidentally have numerous, small knots would be classed as pin oak by this method. No more accurate means of identifying the species by means of the wood alone is known, however.

\section{WILLOW OAK.}

\section{Other Names.}

\section{Quercus phellos Linn.}

Peach oak; water oak. The willow oak belongs to a group of nonevergreen oaks with narrow leaves that are not cut or notched at the edges, known collectively as willow oaks. The other important species are shingle oak and laurel oak.

Geographic Distribution.

See map, page 18.

Distinguishing Characteristics.

The willow oaks belong to the red-oak group. They can not be identified indi. vidually by the wood alone.

\section{OTHER RED OAKS USED FOR TIES AND TIMBERS.}

BLACK JACK (Quercus marilandica Muenchh.), also known as jack oak, iron oak, black oak, barren oak, and scrub oak (S. C.). This species has the distinction of belonging to the red-oak group and yet having the pores densely plugged with tyloses as is the case in the wood of the white-oak group. This feature usually is distinct enough to distinguish the black jack from the other common red oaks, and the pores in the summerwood will distinguish it from the white-oak group. For geographic distribution, see map, page 18.

Spanish oAk (Quercus digitata Marsh.) Sudworth), also known as red oak and Spanish water oak. For geographic distribution, see map, page 18.

TEXAN OAK (Quercus texana Buckl.), also known as red oak, spotted oak, and Spanish oak. A species often not distinguished from the true red oak (Quercus rubra) by woodsmen. For geographic distribution, see map, page 18.

SCARLET OAK (Quercus coccinea Muenchh.), also known as red oak, black oak, and Spanish oak, and not easily distinguished from the true red oak even in the forest. For geographic description, see map, page 16.

TURKEY OAK (Quercus catesbæi Michx.), also known as scrub oak, barren scrub oak, forked leaf (S. C.), and black jack (S. C.). For geographic distribution, see map, page 16.

WATER oAK (Quercus nigra Linn.), also known as spotted oak, duck oak, possum oak, and punk oak. For Geographic distribution, see map, page 16.

LAUREL OAK (Quercus laurifolia Michx.), also known as swamp laurel oak, Darlington oak (S. C.), willow oak, and water oak (Ga.). For geographic distribution, see map, page 18 . 
ShINGle OAK (Quercus imbricaria Michx.), also known as jack oak (111.), water oak (N. C.), and laurel oak. For geographic distribution, see map, page 18.

\title{
CHESTNUT.
}

Other Names.

\author{
Castanea dentata (Marsh.) Borkh.
}

Excepting Indian names, chestnut is not known by any other name.

Geographic Distribution.

See map, page 20.

Distinguishing Characteristics.

Pores.--In the springwood, large and distinct, forming a broad porous ring; in the summerwood, very small and numerous, arranged in irregular branched radial bands. The large pores are almost entirely plugged with tyloses.

Rays.-All very fine, barely distinct with a lens.

Parenchyma.-Scattered among the pores, not distinct.

Annual rings. - Mostly moderate in width, but highly variable.

Sapwood.-Very narrow, rarely over one-haif inch wide.

Heartwood.-Grayish brown.

Physical propreties.-The wood is moderately light, straight-grained, has no pronounced odor, but has a mild astringent taste when chewed.

Similar Woods.

Chestnut is not easily confused with any other species. The radial bands of pores are found in no other wood used for ties, except the oaks, which, however, are easily identified by their greater weight and broad rays. Black ash resembles chestnut, but the pores in black ash summerwood are few and isolated and never arranged in radial bands.

\section{WHITE ELM.}

\section{Other Names.}

\section{Ulmus americana Linn.}

American elm; water elm; swamp elm, rock elm (hard grades).

Geographic Distribution.

See map, page 22.

Distinguishing Characteristics.

Pores.-In the springwood moderately large, forming a porous ring consisting of one row, or, in very wide annual rings, of two or more rows of pores. Throughout the summerwood the pores are very small and numerous and connected into more or less continuous wavy tangential bands. The large pores are mostly open and rarely contain tyloses.

Rays.-Fine, not distinct without a lens.

Parenchyma.-Not noticeable.

Annual rings.-Distinct, moderate in width.

Sapwood.-Mostly between 1 and 3 inches wide.

Heartwood.-Brownish, usually with reddish tinge.

Physical properties.-The wood is moderately heavy, tough, straight-grained, or somewhat cross-grained, and without characteristic odor or taste.

Similar Woods.

Hard grades of white elm are difficult to distinguish from cork elm, but it will be found that the large pores of the springwood are less conspicuous in the cork elm. Compare illustrations. Slippery elm has thinner sapwood and more porous spring. wood than white elm, and the inner bark becomes mucilaginous when chewed.

The elms are closely related to the hackberries; both have the conspicuous wavy tangential lines of pores in the summerwood, but hackberry has the wider sapwood, paler heartwood with slight greenish tinge, and more distinct rays. 


\section{CORK ELM.}

\section{Other Names.}

Ulmus racemosa Thomas.

Rock elm; hickory elm; corkbark elm; corky white elm.

Geographic Distribution.

See map, page 22.

Distinguishing Characteristics.

Pores.-Larger in the springwood than in the summerwood, but not conspicuous because they are comparatively small and are not close together; barely visible without a lens, and usually forming only one row. They are mostly closed with tyloses. Throughout the summerwood they are small and numerous and are arranged in more or less continuous, wavy, tangential bands.

Rays.-Fine, not distinct without a lens.

Parenchyma.-Not noticeable.

Annual rings.-Fairly distinct, moderate in width.

Sapwood.-Three-fourths of an inch to $1 \frac{1}{2}$ inches wide.

Heartwood.-Light brown, often tinged with red.

Physical properties.-The wood is heavy, very tough, mostly cross-grained, and without characteristic odor or taste.

Similar Woods.

Cork elm can be distinguished from the other commercial elms by its greater weight and inconspicuous rows of pores in the springwood.

The wood of the southern Wing Elm (Ulmus alata Michx.) resembles that of the northern cork elm very closely, but is usually more lock-grained

\section{SLIPPERY ELM.}

Other Names.

\section{Ulmus pubescens Walt.}

Red elm; rock elm (Tenn.).

Geographic Distribution.

See map, page 22.

Distinguishing Characteristics.

Pores.-In the springwood, large, forming a porous ring from 2 to 4 pores wide; throughout the summerwood, very small and numerous and arranged in more or less continuous wavy tangential bands. The large pores are mostly open, and contain few tyloses.

Rays. - Fine, not distinct without a lens.

Parenchyma.-Not noticeable.

Annual rings.-Distinct, mostly moderate in width.

Sapwood.-Narrow, mostly less than one-half inch wide, rarely over an incl.

Heartwood.-Brown, with shades of red.

Physical properties.-The wood is moderately heavy, fairly straight-grained, tough, practically tasteless, and has a slight odor resembling the taste of the bark. The inner bark when chewed becomes highly mucilaginous.

Similar Woods.

Slippery elm can most easily be distinguished from similar woods by the mucilaginous character of the inner bark whenever this is present. The other elms have wider sapwood and less porous springwood. Hackberry resembles slippery elm very much in structure, but has very wide sapwood, pale heartwood with a greenish tinge: and distinct rays. 


\section{HACKBERRY.}

Other Names.

Celtis occidentalis Linn.

Sugarberry; nettle-tree; hack-tree (Minn.); bastard elm (N. J.).

Geographic Distribution.

See map, page 20.

Distinguishing Characteristics.

Pores.-In the springwood, large, forming a porous ring two or more (one in narrow annual rings) pores wide. In the summerwood, small and numerous, arranged in more or less continuous wavy tangential bands. In the heartwood the large pores are partly closed with tyloses.

Rays.-Fairly distinct without a lens.

Parenchyma.-Not noticeable.

Annual rings.-Distinct, irregular in width and outline.

Sapwood.-Wide, usually over 3 inches, often blued with sap stain.

Heartwood.-Not always distinctly defined; yellowish or greenish gray.

Physical properties.-The wood is moderately heavy, fairly straight-grained, and without characteristic odor or taste.

Similar Woods.

Hackberry resembles elm in structure; but the wide sapwood, greenish yellow tinge in the heartwood, and wider rays in the hackberry are sufficient to distinguish it from the elm.

The wood of Sugarberry (Celtis mississippiensis, Bosc.) resembles hackberry wood very much and often is sold under that name. It grows from southern Illinois and Indiana southward to Florida and Texas.

\section{OSAGE ORANGE.}

Other Names.

\section{Toxylon pomiferum Raf.}

Bois d'arc; mock orange; hedge-plant; yellowwood (Tenn.).

Geographic Distribution.

See map, page 20. This species is planted considerably for hedges outside of its natural range.

Distinguishing Characteristics.

Pores.-Large in the springwood, forming a lighter colored ring; not distinct individually, because they are densely plugged with tyloses, except in the outer annual ring or two of the sapwood. In the summerwood the pores are very small and grouped in short, wavy, tangential bands.

Rays.-Fine, barely visible without a lens.

Parenchyma.-Not distinguishable with a hand lens from the fine pores of the summerwood.

Annual rings.-Distinct, irregular in width and outline.

Sapwood.-Very narrow, usually less than one-half inch wide.

Heartwood.-Freshly cut surfaces are golden yellow to golden brown with reddish brown streaks, turning darker on exposure to the air. Color easily soluble in water.

Physical properties.-The wood is very heavy, exceedingly hard, somewhat crossgrained, and without characteristic odor or taste.

Similar Woods.

Osage orange resembles black locust so much in structure, color, and weight that it is exceedingly difficult at times to distinguish the two. The coloring matter in osage orange is highly soluble, however, and a wet rag or blotter applied to the surface of the wood will be stained yellow in less than 10 minutes; practically no color is re- 
moved from black locust by this method. Fresh surfaces of osage orange are yellowish or golden brown; on black locust they are more of a russet brown. Osage orange ties contain numerous pin knots, which are scarce in black locust.

\section{BLACK LOCUST.}

Other Names.

\section{Robinia pseudacacia Linn.}

Yellow locust; false acacia; pea-flower locust; green locust; post locust. Geographic Distribution.

See map, page 20. This species is planted abundantly outside of its natural range. Distinguishing Characteristics.

Pores.-In the springwood, comparatively large but densely plugged with tyloses which cause them to appear to the unaided eye as a light-colored band rather than as a porous ring (under a lens it can be seen that this band is 2 or 3 rows of pores wide). In the summerwood, very small; in the outer portion of the summerwood, grouped in short, wavy tangential bands.

Rays.-Not visible or barely visible without a lens.

Parenchyma.-Not noticeable around the larger pores with an ordinary hand lens, and not distinguishable from the finer pores of the outer summerwood.

Annual rings.-Distinct, variable in width.

Sapwood.-Narrow, rarely over one-half inch wide.

Heartwood.-Golden brown, sometimes with a tinge of green.

Physical properties.-The wood is very, very heavy and exceedingly hara. It is mostly straight-grained and without distinct characteristic odor or taste.

similar Woods.

The wood of black locust is easily confused with that of osage orange, being similar in weight, structure, color, and other properties. The locust has a russet brown color, while fresh surfaces of csage orange are more of a yellowish or golden brown, often with reddish brown streaks. The color of the osage orange is readily soluble in water, and pieces of the wood placed on a wet rag soon color the cloth yellow; but practically no color can be extracted with cold water from black locust. Rather large wormholes may be found in a large proportion of locust ties. These holes are caused by a grub or larva, known as the locust borer, which does not attack the osage orange.

\section{RED MULBERRY.}

Other Name.

Morus rubra Linn.

Black mulberry.

Geographic Distribution.

See map, page 22.

Distinguishing Characteristics.

Pores.-Large in the springwood, forming a porous ring from 2 to 5 pores wide; in the summerwood, small, in irregular groups of from 3 to 10 pores, the groups usually arranged so as to form wavy, tangential bands visible without a lens.

The large pores in the springwood are densely plugged with glistening tyloses.

Rays.-Fairly conspicuous without a lens.

Parenchyma.-Not distinctly noticeable with a lens.

Annual rings.-Distinct, usually moderate in width.

Sapwood.-About one-half inch wide; yellowish.

Heartwood.-Freshly cut strfaces yellowish brown, becoming russet brown on exposure to air.

Physical properties.-The wood is heavy, fairly straight-grained, and without characteristic odor or taste. 
Similar Woods.

Red mulberry is not easily confused with other woods. The yellowish brown color of freshly exposed surfaces together with the narrow sapwood, distinct rays, and glistening tyloses is sufficient to distinguish it from all other native species.

\section{HARDY CATALPA.}

Other Names.

Catalpa speciosa Warder.

Western catalpa; cigartree; Indian bean.

Geographic Distribution.

See map, page 30. The catalpa is planted in many States outside of its natural range.

Disinguishing Characteristics.

Pores.-In the springwood, large and distinct, forming a broad porous ring; in the middle of the annual ring, smaller, but usually visible without a lens, isolated, or in groups of from two to five, or more often in slightly wavy, tangential lines; in the outer part of the summerwood, very small and always in wavy, tangential lines. The larger pores are more or less plugged with glistening tyloses.

Rays.-Very fine, not distinct without a lens.

Parenchyma. - Not noticeable around the larger pores and not distinguishable from the very small pores of the outer summerwood.

Annual rings.-Usually wide; but narrow-ringed specimens may also be found.

Sapwood.-Very narrow, rarely over one-half inch wide.

Heartwood.-Grayish brown, occasionally with a lavender tinge.

Physical properties.-The wood is moderately light, straight-grained, and without pronounced taste or odor. Sometimes it has a slight odor resembling kerosene.

Similar Woods.

Sassafras and black ash resemble catalpa in color and somewhat in structure. Sassafras can easily be identified by its spicy odor; black ash is considerably heavier than catalpa and has comparatively few pores in the summerwood. In catalpa the pith usually is three sided and in black ash round.

The wood of the Common Catalpa (Catalpa catalpa (Linn.) Karst.) resembles that of the hardy catalpa so closely that the two can not readily be distinguished. The common catalpa is supposed to be indigenous only to southwestern Georgia, western Florida, central Alabama, and Mississippi, but it is widely cultivated and naturalized elsewhere east of the Rocky Mountains.

\section{HONEY LOCUST.}

Other Names.

Gleditsia triacanthos Linn.

Thorny locust; honey shucks; sweet locust; three-thorned acacia.

Geographic Distribution.

See map, page 30.

Distinguishing Characteristics.

Pores.-Comparatively large in the springwood; conspicuous without a lens, form. ing a wide porous ring which occupies about one-half the total width of moderately wide annual rings. In the outer portion of the summerwood, very small, openings not clearly visible with an ordinary lens; joined in short, wavy, lighter-colored, tangential bands, distinct to the unaided eye. The large pores in the springwood are not closed with tyloses but occasionally contain a bright reddish gum.

Rays.-Mostly very distinct without a lens.

Parenchyma.-Not noticeable around the larger pores and not readily distinguish. able from the small pores in the summerwood.

Annual rings.-Distinct; irregular in width and outline. 
Sapwood.-From three-fourths of an inch to 2 inches wide on tie material.

Heartwood.-Bright cherry red to reddish brown.

Physical properties.-The wood is very heavy, fairly straight grained, and without characteristic odor or taste.

Similar Woods.

On account of the similarity in the color and general structure of the wood of the honey locust and the coffeetree, the two are often confused in the market. The coffeetree, however, has a narrower sapwood and a much larger pith. The pith in honey locust is usually less than 0.15 inch in diameter; in coffeetree it usually is over 0.2 inch in diameter. The pores in the outer summerwood of the coffeetree are somewhat larger (the openings being plainly visible with a good lens), and are more often in rounded groups which are not joined in tangential bands. The rays in coffeetree wood are less distinct to the unaided eye than those in honey locust. Scattered, small pin knots, due to the thorns which grow on the trunks, are found in honey locust, but never in coffeetree.

\section{COFFEETREE.}

Other Names.

Gymnocladus dioicus (Linn.) Koch.

Kentucky coffeetree; coffee nut; coffee-bean tree.

Geographic Distribution.

See map, page 20.

Distinguishing Characteristics.

Pores.-In the springwood, large and distinct, forming a porous ring from 2 to 5 pores wide; in the summerwood, small, but the opening still visible with a good lens; arranged in rounded groups of from 4 to 20 or more, the groups occasionally joined in tangential bands in the extreme outer portion of the annual rings. The large pores are not plugged with tyloses, but occasionally contain an orange-reddish gum.

Rays.-Visible without a lens, but not conspicuous.

Parenchyma.-Not noticeable with a lens.

Annual rings.-Distinct, highly variable in width.

Sapwood.-Narrow, usually less than one-half inch wide, but occasionally as much as 1 inch.

Heartwood.-Bright cherry red to reddish brown.

Physical properties.-The wood has about the same weight and properties as that of the honey locust.

Similar Woods.

The wood of the coffeetree is not easily confused with any wood except that of honey locust, which has practically the same color and almost the same structure. For distinguishing these two woods, see keys or distinctions made under the heading Honey Locust.

\section{WHITE ASH.}

Other Names.

Fraxinus americana Linn.

American ash; cane ash.

Geographic Distribution.

See map, page 30 .

Distinguishing Characteristics.

Pores.-Comparatively large in the springwood, forming a porous ring 2 or 3 or, in wide rings, 4 pores wide; in the summerwood, very small, appearing to the unaided eye as white specks, not numerous, scattered singly or by twos. The larger pores, excepting those of the outer sapwood, contain numerous tyloses.

Rays.-Very fine, not distinct without a lens.

Parenchyma.-Distinct as a light-colored area around the pores of the summerwood, often projecting tangentially and connecting pores somewhat separated, thereby 
forming wavy, tangential lines visible without a lens, especially in the outer part of wide annual rings.

Annual rings. - Very distinct, mostly moderately wide.

Sapwood.-Several inches wide.

Heartwood.-Grayish brown, sometimes with a reddish tinge.

Physical properties. - The wood is highly variable in weight, and some surprisingly light pieces are occasionally found; it averages about 34 pounds per cubic foot ovendry based on green volume. It is straight-grained and without characteristic odor or taste.

Similar Woods.

About 18 different species of ash are known in this country; but white, green, and black ash form about 98 per cent of the commercial cut. Most of the ash ties or timbers are either white or green ash, black ash being used comparatively little for this purpose.

The wood of Green AsH (Fraxinus lanceolata Borkh.) resembles white ash very much. The rings in the green ash average wider than those in white ash, but this feature can not be relied on for identification of species. The tangential lines of parenchyma connecting the pores in the summerwood are longer and more numerous in green ash than in white ash. Commercially, no distinction is generally made between the two species. For geographic distribution see map, page 30 .

Black AsI (Fraxinus nigra Marsh.), also known as hoop ash, differs from green and white ash in being of lighter weight (about 29 pounds per cubic foot oven-dry based on green volume), in having darker heartwood, and in having comparatively narrow sapwood, rarely over an inch and usually about one-half inch wide. Projections of parenchyma from the pores of the summerwood are rare, and for this reason the tangential bands so plain in the summerwood of green ash are somewhat obscure in black ash. For geographic distribution see map, page 30 .

Chestnut, catalpa, and sassafras resemble the ashes, especially black ash. In chestnut the pores in the summerwood are numerous and in radial bands; in catalpa and sassafras they are also numerous but in tangential bands; while in the ashes they are few and scattering, usually surrounded by parenchyma in such a way as to appear in tangential bands in the outer portion of the summerwood. Sassafras can readily be distinguished from the ashes by its spicy odor or taste.

\section{SASSAFRAS.}

Other Name.

Sassafras sassafras (Linn.) Karst.

\section{Saxifrax.}

Geographic Distribution.

See map; page 30.

Distinguishing Characteristics.

Pores.-The large pores in the springwood form a broad ring from three to five or even seven pores wide; in the summerwood the pores are very small (not visible without a lens), mostly isolated or in radial rows of two or three, and not crowded. The large pores contain numerous tyloses.

Rays.-Fine, but distinct without a lens.

Parenchyma.-Noticeable as a narrow lighter-colored area around the pores of the summerwood, in the outer portion often extending a little tangentially from the pores and appearing to connect them in wavy, tangential lines.

Annual rings.- Very distinct, moderate in width.

Sapwood.-Narrow, rarely over one-half inch wide.

Heartuood.-A light silvery brown.

Physical properties.-The wood is moderately heavy and straight-grained and has a spicy odor and taste. 
Similar Woods.

Sassafras wood resembles the wood of the ashes, especially black ash, and of catalpa in color and structure, although the sapwood is much narrower than that of the white and green ash. The spicy odor and taste, however, are sufficient, except when the wood has been treated with a preservative, to distinguish it from all other native woods used for ties.

Other Names.

\section{PERSIMMON.}

\section{Diospyros virginiana Linn.}

Date plum; possumwood (Fla.).

Geographic Distribution.

See map, page 20.

Distinguishing Characteristics.

Pores.-Comparatively large, especially in the springwood, decreasing in size, somewhat abruptly or gradually (then classed as diffuse-porous) toward the summerwood; easily visible without a lens except in the outer portion of the annual ring; not crowded; occasionally in rows of from two to five. Tyloses absent.

Rays.-Very fine even under a lens. On the tangential surface they appear in tiers or stories producing very fine bands running across the grain and visible with the naked eye.

Parenchyma.-Visible with a lens as numerous very fine, light-colored, irregular, tangential lines no wider than the rays.

Annual rings.-Mllarked by a row of larger pores at the beginning of each year's growth, but not conspicuous because the pores are not numerous and decrease in size more or less gradually toward the outer portion of each ring.

Sapwood.-Wide, from 2 to 4 or 5 inches; white when fresh, but sometimes stained a grayish brown when exposed to the air for some time.

Heartwood.-Jet black or blackish brown, irregular in outline and usually very small.

Physical properties.-The wood is from very heavy to very, very heavy, straight or wavy-grained, and without charcteristic odor or taste.

Similar Woods.

Persimmon can not be mistaken for any other wood when the black heart is present. Pieces of sapwood resemble hickory sapwood in weight and in having comparatively large pores and fine lines of parenchyma, but can be distinguished by the fine horizontal bands on the tangential surface, which are due to the storied arrangement of the rays.

\section{THE HICKORIES.}

Comparatively fow hickory ties are used, but occasionally some are sold with other hardwoods. Eight species of hickory are of commercial importance and several other species of minor value have been named by botanists. According to the leaves, twigs, and fruit the species can be divided into two groups, the true hickories, and the pecan hickories. No method has as yet been determined for identifying each species of the wood alone, except water hickory, which has a distinct structure; and often it is impossible without the aid of a compound microscope eren to determine to which group a piece of hickory belongs.

The following features are characteristic of all the hickories except the water hickory. 
Pores.-Plainly visible with the unaided eye in the springwood, forming a ring 1 to 2 or 3 pores wide; decreasing in size somewhat gradually toward the summerwood, in which they are smaller but still occasionally visible without a lens. In the summerwood, not numerous, isolated or in radial groups of two or three.

Most of the larger pores, except those in the outer sapwood, are filled with tyloses.

Rays. - Rather fine, not distinct without a lens.

Parenchyma.-In numerous fine, light-colored, tangential lines not widening out and encircling the pores as in ash, but usually extending between the pores or passing around them on one side; very plain under a lens and sometimes visible without a lens.

Annual rings.-Clearly defined; highly variable in width.

Sapwood.-From 1 to 2 and occasionally as much as 3 inches wide on ties.

Ilcartwood.-Brown to reddish brown.

Physical properties.-The wood of the hickories is very heavy and exceedingly hard and tough. It has no characteristic odor or taste.

Similar Woods.

The hickories can be distinguished from other ring-porous woods by the numerous fine, light-colored, tangential lines of parenchyma and the presence of few pores in the summerwood. Persimmon is somewhat similar to hickory in these respects; but in the persimmon the tangential lines are much the finer, and the medullary rays are in horizontal rows plainly noticeable on the tangential surfaces as very fine bands across the grain.

The following species may occasionally be cut for ties:

\section{TRUE HICKORIES.}

Shagbark (Hickory) (Hicoria ovata (Mill.) Britton), also named shellbark, scalybark, and upland hickory (Ill.). For geographic distribution see map, page 26 .

Shellbark (Hickory) (Hicoria laciniosa (Michx. f.) Sargent), also known as shellbark, western shellbark, thick shellbark, bottom shellbark (Ill.), kingnut, yellow-twig hickory, and big-fruited shellbark. For geographic distribution see map, page 26.

Pignut (Hickory), or Black Hickory (Hicoria glabra (Mill.) Britton), also known as switch-top hickory and tight-bark hickory. For geographic distribution see map, page 26 .

Mockernut (Hickory) (Hicoria alba (Linn.) Britton), also known as whiteheart hickory, big-bud hickory, white hickory, and hognut. For geographic distribution see map, page 26 .

\section{PECAN HICKORIES.}

Bitternut (Hickory) (Hicoria minima (Marsh.) Britton), often named pignut, also swamp hickory, pig hickory, bitter hickory, and willow hickory. For geographic distribution, see map, page 28.

Pecan (Hickory) (Hicoria pecan (Marsh.) Britton). For geographic distribution, see map, page 28.

NutMeg Hickory (Hicoria myristicœformis (Michx. f.) Britton), also known as bitter waternut. For geographic distribution, see map, page 28.

Water Hickory (Hicoria aquatica (Michx.f.) Britton), also known as bitter pecan, swamp hickory, and water bitternut. For geographic distribution, see map, page 28.

Water hickory differs from the other hickories in having less clearly defined annual rings, and in the large pores being more scattered, thus approaching diffuse-porous woods in structure. See illustration. The fine, light-colored lines of parenchyms characteristic of the hickories are very distinct in this species. The color of the heartwood is about the salue as in the other hickories, but the wood is somewhat lighter in weight.

$96625^{\circ}-17-4$ 


\section{SYCAMORE.}

Other Names.

Platanus occidentalis Linn.

Button-wood; buttonball-tree; plane-tree; water beech (Del.).

Geographic Distribution.

See map, page 20.

Distinguishing Characteristics.

Pores.-Very small, not visible without a lens or indistinctly visible in vigorous growth; crowded and of about uniform size throughout the annual ring except in the extreme outer portion, in which they are smaller and less numerous and produce a narrow, lighter colored band.

Rays.-Practically all comparatively broad and conspicuous; many over twice as wide as the largest pores; appearing on a radial surface as reddish brown "flakes," or "silver grain" similar to quartered oak, but finer.

Parenchyma.-Not noticeable even with a lens.

Annual rings.-Distinct, defined by a lighter colored band at outer limit of each; not differentiated into distinct springwood and summerwood.

Sapwood.-One and one-half to 3 inches wide.

Heartwood.- - Light to moderately dark shades of reddish brown, sometimes not clearly defined from sapwood.

Physical properties.-The wood is moderately heavy, lock-grained, and without characteristic odor or taste. Cup shake, especially in butt logs, is a common defect. Similar Woods.

Sycamore is not easily confused with other woods. Its numerous conspicuous medullary rays and interlocked grain make it easily recognizable. It resembles beech somewhat, but can be distinguished from it by the rays, only a small proportion of which are broad in beech. Beech also has a distinct darker and denser band of summerwood.

\section{BEECH}

Other Names.

Fagus atropunicea (Marsh.) Sudworth.

Only one species of beech is native to the United States; but because of the variability in the color of the heartwood the darker grades have been designated as redheart beech and the lighter grades as white-heart beech.

Geographic Distribution.

See map, page 30 .

Distinguishing Characteristics.

Pores.-Very small, not visible without a lens; crowded in the springwood but gradually decreasing in size and number toward the outer portion of the annual ring, forming a harder and darker band of summerwood.

Rays.-About 1 in from 10 to 20 of the rays seen on a smooth end surface is conspicuously broad and distinct without a lens. These large rays appear on the radial surface as small reddish brown "flakes" or "silver grain." The large rays are fully two times as wide as the largest pores, but the others are much narrower than the pores, and not visible without a lens.

Parenchyma.-Very fine, irregular, light-colored, tangential lines may be seen with a lens in some specimens, but usually they are not distinct.

Annual rings.-Distinct but not very conspicuous; defined by the sharp contrast between the harder and darker band of summerwood and the succeeding lighter colored and more porous springwood.

Sapwood.-Variable in thickness from 2 to 5 inches.

Heartwood.-Variable from reddish brown to almost white with a reddish tinge and then not clearly defined from the sapwood. 
Physical properties.-The wood is heavy, fairly straight-grained, and without characteristic odor or taste.

Similar Woods.

Sycamore and maple resemble beech but can be distinguished from it as follows: In sycamore practically all the rays are broad and conspicuous, and the outer portion of each annual ring is lighter colored. In maple the rays are all narrower than the larger ones in beech, although they are still plainly visible without a lens, and there is practically no distinction between springwood and summerwood.

\section{SUGAR MAPLE.}

Other Narnes.

Acer saccharum Marsh.

Hard maple; rock maple; sugar-tree; black maple.

Geographic Distribution.

See map, page 22.

Distinguishing Characteristics.

Pores.-Small, not visible with the unaided eye; round, nearly always isolated, rarely in radial rows of two or three; practically uniform in size throughout the growth ring; not crowded.

Rays.-Two kinds; some very distinct without a lens, fully as wide as the largest pores, except near the center of a tree, and conspicuous on a radial cut as small, reddish brown "flakes;" others very fine, barely visible with a lens.

Parenchyma.-Not noticeable.

Annual rings.-Not very distinct; defined by a reddish brown line. Pith flecks rarely present.

Sapwood.-Several inches wide; white with slight reddish brown tinge.

Heartwood.-Light reddish brown.

Physical properties. - The wood is heavy, difficult to cut across the grain, straightgrained (occasionally it has a wavy or bird's-eye grain) and without characteristic odor or taste.

Simılar Woods.

The soft maples (silver maple and red maple) resemble the sugar maple, but the wood of the sugar maple is usually distinctly heavier and harder. The rays in the soft maples are of more uniform width and not so large as the broadest ones in the sugar maple. The birches and beech resemble maple somewhat. However, in birch the rays are not distinct without a lens, while the pores usually are; and in beech the widest rays are much wider than the largest pores.

\section{SILVER MAPLE.}

Other Names.

Acer saccharinum Linn.

Soft maple; white maple; river maple; water maple; swamp maple.

Geographic Distribution.

See map, page 22.

Distinguishing Characteristics.

Pores.-Not visible without a lens; evenly scattered throughout the annual rings; mostly isolated but occasionally in radial rows of from two to four; not crowded.

Rays.-Visible without a lens except near the center of the tree, practically all of about uniform width, but usually not so large as the largest pores, not so conspicuous on the radial surface as in the sugar maple.

Parenchyma.-Not visible.

Annual rings. - Not very distinct; defined by a fine, darker line. Pith flecks usually abundant, although they may be absent in some pieces.

Sapwood.-Wide; white. 
Heartwood.-Light reddish brown.

Physical properties.-The wood is moderately heavy, straight-grained, easily cut accoss the grain, and without characteristic odor or taste.

Similar Woods.

Silver maple can usually be distinguished from sugar maple by its lighter weight and abundant pith flecks. Or by examining the end surfaces with a lens, it will be found that in silver maple all the rays are practically of the same width, while in sugar maple some are conspicuously wide and others very narrow. Silver maple also resembles the river birch, but in the river birch the rays are narrower (not visible without a lens) and the pores larger (usually visible without a lens).

Red Maple (Acer rubrum Linn.) is also classed as soft maple and resembles silver maple very much, although the wood averages slightly heavier and stronger. Both grow practically in the same region. See map, page 22.

\section{BLACK CHERRY.}

Other Names.

Prunus serotina Ehrh.

Wild cherry; rum cherry.

Geographic Distribution.

See map, page 32 .

Distinguishing Characteristics.

Pores.-Small, not visible with the unaided eye, evenly distributed or gradually decreasing in size and number toward the end of each annual ring; isolated or in irregular groups of from two to four; numerous, occupying one-third, or slightly more, of the space between the rays.

Rays.-Very distinct on end and radial surfaces; as wide or almost as wide as the largest pores.

Parenchyma.-Not noticeable.

Annual rings.-Fairly distinct; defined by an abrupt difference in the size of the pores in the summerwood and succeeding springwood; much more pronounced in some samples than in others. Pith flecks occasionally present but inconspicuous because the color is the same as that of the surrounding wood.

Sapwood.-Narrow, usually less than 1 inch.

Heartwood.-Reddish brown in varying shades from moderately dark to very dark.

Physical properties.-The wood is moderately heavy, fairly straight-grained, and without characteristic odor or taste.

Similar Woods.

Other woods are rarely confused with cherry. The reddish brown color and very distinct rays serve to distinguish black cherry from all other native commercial woods.

\section{BLACK WALNUT.}

Other Names.

Juglans nigra Linn.

Unlike most of our native trees, black walnut is known throughout the country by only one name. Occasionally it is named merely "walnut" for convenience, but this is not considered a distinct name.

Geographic Distribution.

See map, page 30.

Distinguishing Characteristics.

Pores.-Comparatively large and easily visible with the naked eye, especially in the springwood, and gradually decreasing in size toward the outer portion of each annual ring. (Although at first sight some pieces may give the impression of being ringporous, they are not classed as such because the large pores in the beginning of each annual ring do not form a definite zone beyond which they decrease abruptly in size.) Tyloses present, but not filling the pores completely. 
Rays.-Very fine and inconspicuous, not distinct without a lens.

Parenchyma.-Present in the form of several lighter colored, irregular, tangential lines readily visible in the sapwood but obscure in the heartwood.

Annual rings.-Distinct; marked by an abrupt difference in the size of the pores in the summerwood and succeeding springwood, and by a fine, light-colcred line.

Sapwood.-Narrow, mostly less than 1 inch wide, but occasionally up to 3 inches; white, or discolored to yellowish or purplish brown.

Heartwood.- Rich chocolate brown with lustrous surface.

Physical properties.-The wood is heavy, straight-grained, and practically tasteless, but has a slight characteristic odor, especially when worked. Although the wood is not very dense, it will readily turn the edge of the woodworking tools because of the numerous crystals of mineral matter imbedded in the cells.

Similar Woods.

The color and the large pores of black walnut readily distinguish it from other woods. Butternut resembles it most closely but is lighter in color and considerably lighter in weight.

\section{BUTTERNUT.}

Other Names.

\section{Juglans cinerea Linn.}

White walnut; walnut.

Gcographic Distribution.

See map, page 30 .

Distinguishing Characteristics.

Pores.-Comparatively large and easily visible with the na'ied eye, especially in the springwood; gradually decreasing in size toward the outer portion of each annual ring; not crowded; occasionally in radial rows of from two to six. (On account of the difference in size of the pores of the summerwood and the succeeding springwood, some pieces approximate ring-porous woods in appearance but are not classed as such because the large pores in the beginning of each annual ring do not form a definite zone beyond which the pores abruptly decrease in size.) Tyloses are present, but do not appear to plug the pores completely.

Rays.-Very fine and inconspicuous; indistinct without a lens.

Parenchyma.-Visible as fine, tangential lines when the surface is smoothed with a very sharp knife; sometimes not distinct.

Annual rings.-Distinct; marked by abrupt difference in the size of the pores in the summerwood and the succeeding springwood; usually wider than in black walnut.

Sapwood.-Narrow, rarely over 1 inch wide; white to light brown.

Heartwood.-Light chestnut brown with occasional reddish tinge.

Physical properties.-The wood is moderately light, straight-grained, and without characteristic odor or taste. It cuts easily and does not readily turn the edge of a blade as does black walnut.

Similar Woods.

The plainly visible pores, which gradually decrease in size toward the outer edge of each annual ring, and the light chestnut brown color distinguish butternut from other woods. It is lighter in color and considerably lighter in weight than black walnut, to which it is closely related.

\section{YELLOW BIRCH.}

Otiner Nimes.

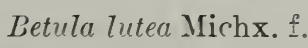

Gray birch; silver birch; swamp birch (Minn.).

Geographic Distribution.

See map, page $2:$. 
Distinguishing Characteristics.

Pores.-Usually not distinct to the unaided eye; clearly visible, however, in some pieces; not crowded, occupying less than one-third of the total area between the rays except in very narrow rings; occasionally in radial rows of from two to four. Tyloses absent.

Rays.-Fine, not distinctly visible without a lens; appearing on the radial surface as very fine reddish brown "flakes."

Parenchyma.-Not noticeable.

Annual rings.-Not distinct to the unaided eye except in specimens showing rapid growth; defined by a fine line and a slight decrease in the size of the pores at the end of each year's growth. Pith flecks usually absent.

Sapwood.-Several inches in width, but extremely variable in different pieces.

Heartwood.-Reddish brown.

Physical properties.-The wood is heavy, straight-grained, and without characteristic odor or taste. The inner bark has a mild wintergreen flavor.

Similar Woods.

River birch resembles yellow birch somewhat, but usually has abundant pith flecks. The maples also resemble the birches, but have smaller pores and wider rays. Neither the river birch nor the maples have the wintergreen flavor in the inner bark characteristic of the sweet and yellow birches.

SweEt Birch (Betula lenta Linn.), also known as cherry birch and black birch, is often associated with yellow birch but is not so plentiful. The wood resembles yellow birch so closely that is it difficult to distinguish between the two. The inner bark has a decided wintergreen flavor, which is more pronounced than in yellow birch. The outer bark of yellow birch is yellowish gray and readily separates into thin, papery layers; of sweet birch it is reddish brown and not papery. For geographic distribution see map, page 24 .

Paper Birch (Betula papyrifera Marsh.) of the Northern States, also known as white birch and canoe birch, is used for ties only locally. In general, it has the same structure as the other birches, except that the pores are smaller and can not be seen without a lens. Pith flecks are common but may be absent. The wood is lighter and softer than that of yellow or sweet birch. The sapwood is comparatively wide and almost white. The outer bark separates readily into white papery layers. For geographic distribution see map, page 24.

\section{RIVER BIRCH.}

Other Names.

Betula nigra Linn.

Red birch; water birch; black birch.

Geographic Distribution.

See map, page 24.

Distinguishing Characteristics.

Pores.-Usually visible with the unaided eye, although not always distinct; slightly smaller in the extreme outer portion of the annual ring; not crowded, although more numerous than in sweet or yellow birch and often occupying more than one-third of the total area between the rays; isolated, or in rows of from two to four. Tyloses absent.

Rays.-Very fine, not visible without a lens.

Parenchyma.-Not noticeable.

Annual rings.-Indistinct without a lens except by careful observation; defined by a fine line and in some cases by a slight decrease in the size of the pores at the ond of each year's growth. Pith flecks abundant.

Sapwood.-Wide, faintly reddish brown; transition to heartwood gradual.

Heartwood.-Reddish brown. 
Physical properties.-The wood is heavy, straight-grained, and without characteristic odor or taste.

Similar Woods.

River birch can be distinguished from the sweet and yellow birches by its abundant pith flecks and lack of wintergreen flavor in the inner bark. It may be confused with the soft maples, which also have many pith flecks and are only slightly lighter in weight; but the rays in the soft maples are more conspicuous and the pores are much smaller. The outer bark of the river birch is light reddish brown and readily separates into small crumpled flakes, but not into papery layers, as does that of the yellow and paper birches.

\section{COTTONITOOD.}

Other Names.

Populus deltoides Marsh.

Poplar (in the Northern States); cotton-tree; whitewood.

Geographic Distribution.

See map, page 20.

Distinguishing Characteristics.

Pores.-Usually visible with the unaided eye, especially in the springwood; decreasing slightly in size toward the outer portion of each annual ring; very numerous, occupying nearly one-half of the total area between the rays except in very wide rings; scattered singly, or often in radial rows of from two to four.

Rays.-Invisible without a lens and barely distinct with a lens.

Parenchyma.-Not noticeable.

Annual rings.-Distinct but not conspicuous; defined by a slight difference in the size of the pores of the summerwood and of the succeeding springwood. Pith flecks occasionally present, but not conspicuous.

Sapwood.-Not clearly defined, and passing more or less gradually into the heartwood.

Heartwood.-Grayish white to light grayish brown.

Physical properties.-The wood is light and fairly straight-grained (occasionally cross-grained). It is practically tasteless, but has a characteristic disagreeable odor when moist.

Similar Woods.

Cottonwood may be confused with other light woods like tupelo, yellow poplar, basswood, and buckeye. It can be distinguished from these by the fact that the pores in its springwood are larger, being usually visible without a lens.

This description of the common cottonwood also applies to the BLACK CotTonwood (Populus trichocarpa Torr. and Gr.), or balm, found west of the Rocky Mountains. See map, page 20.

The Swamp Cоттолwoon (Populus heterophylla Linn.), found in the Atlantic and Gulf coast region and the Mississippi Valley, is practically identical in structure with the common cottonwood, but it has a slightly darker heartwood.

Aspen (Populus tremuloides Michx.) and Largetooth Aspen (Populus grandidentata Michx.) are closely related to the cottonwoods. The wood of these species resembles cottonwood very much, but is of a finer texture, the pores being smaller and not visible without a lens.

\section{RED GUM.}

Other Names.

Liquidambar styraciflua Linn.

Sweet gum; liquidambar; gum-tree; star-leaved gum; alligator-wood (N. J.).

Geographic Distribution.

See map, page 30. 


\section{Distinguishing Characteristics.}

Pores.-Very small, not visible without a lens; uniform in size and evenly distributed throughout each annual ring; crowded, occupying from one-half to two-thirds of the space between the rays; occasionally joined in short radial rows of from two to five, but more often in rows with narrow spaces between the pores.

Rays.-Fairly distinct without a lens; comparatively numerous.

Parenchyma.-Not noticeable.

Annual rings.- Not distinct even with a lense, defined by a lighter colored line. Sapwood.-Variable, from 1 to 5 inches, in width; white, with reddish tinge or blued by sap stain.

Heartwood.-In varying shades of reddish brown, with darker streaks in some pieces.

Physical properties.-The wood is moderately heavy, somewhat lock-grained, and without characteristic odor or taste.

Similar Woods.

The dark reddish brown heartwood of red gum is so characteristic that it usually serves to distinguish the species from all other woods used for ties.

Cherry also has a dark, reddish brown heartwood, but it is usually darker, more lustrous, and has more distinct rays.

\section{BLACK GUM.}

Other Names.

Nyssa syliatica Marsh.

Sour gum; pepperidge; tupelo; gum; tupelo gum (Fla.).

Geographic Distribution.

See map, page 24.

Distinguishing Characteristics.

Pores.-Very small, not visible without a lens; not diminishing in size or number toward the outer portion of the annual ring except in very wide rings; mostly solitary, especially in dense pieces, but occasionally in radial rows of from two to five; crowded in lighter pieces, but in heavier pieces occupying less than one-third of the total area between the rays.

Rays.- Usually not distinct to the unaided eye but distinct with a lens; not conspicuous on the radial surface, being small and of the same color as the surrounding wood.

Parenchyma.-Not noticeable.

Annual Rings. - Indistinct, even under a lens; defined by a fine line and occasionally by a slight decrease in the size of the pores at the extreme outer edge of the ring.

Sapwood.-Varying from one to several inches in width, and passing more or less gradually into the heartwood.

Heartwood.-Brownish gray in color.

Physical properties.-The wood is moderately heavy to heavy, very lock-grained, which makes it exceedingly difficult to split, and without characteristic odor or taste. Similar Woods.

Cotton gum, or tupelo, can not be easily distinguished from black gum, although it averages somewhat lighter in weight. The pores are slightly larger in tupelo and more often in radial rows, but this difference can be observed only by comparing woods of the two species. The brownish gray color, together with the interlocked grain, readily distinguishes black gum from most other woods.

The Water Gum (Nyssa biflora Walt.) of the Atlantic and Gulf coasts also resembles black gum so much that the two can not be easily distinguished. For geographic distribution, see map, page 24 . 


\section{COTTON GUM (TUPELO).}

Other Names.

Nyssa aquatica Linn.

Large tupelo; bay poplar; sour gum; wild olive tree (La.); swamp tupelo.

Geographic Distribution.

See map, page 24.

Distinguishing Characteristics.

Pores.-Not visible without a lens, uniformly distributed throughout the annual rings or slightly less numerous in the outer part; often in radial rows of from three to six, noticeable especially in the less porous pieces; widely variable in numbers, from moderately abundant to crowded. (In light grades the cavities of the wood fibers between the larger pores can also be seen with a lens, but they are always smaller than the true pores.)

Rays.-Very fine even under a lens.

Parenchyma.-Not noticeable.

Annual rings.--Not distinct even under a lens; defined by a light-colored line, and in wide rings by a slight decrease in the number and size of the pores at the end of each year's growth.

Sapwood.- Several inches wide, passing more or less gradually into the heartwood.

Heartwood.-Pale brownish gray.

Physical properties.- Wood moderately heavy, usually lighter and softer in the butt $\log$ than near the top, lock-grained, and without characteristic odor or taste.

Similar Woods.

Heavier grades of cotton gum are difficult to distinguish from black gum. Although the pores are slightly larger in cotton gum and more often in radial rows, this difference can be noticed oniy by comparing samples of the two species.

Cotton gum may be confused with cottonwood; but the interlocked grain and smaller pores found in cotton gum help to distinguish it from cottonwood, which usually is fairly straight grained and has pores large enough to be seen without a lens.

\section{YELLOW POPLAR.}

Other Names.

\section{Liriodendron tulipifera Linn.}

Tulip poplar; poplar; whitewood (second growth containing much white sapwood); white poplar; blue poplar; hickory poplar.

Geographic Distribution.

See map, page 20.

Distinguishing Characteristics.

Pores.-Not visible without a lens; uniformly distributed throughout the annual ring; isolated or occasionally in short radial rows of from two to five, rarely joined tangentially except where the pores are crowded; usually numerous, occupying over half of the area between the rays, but in comparatively dense pieces occupying a little over one-third of the area between rays, and in such pieces rarely in rows.

Rays.-Distinct without a lens, fairly conspicuous under a lens.

Parenchyma.-Confined to a narrow light-colored layer on the outer portion of the annual rings.

Annual rings.-Defined by a distinct light-colored line.

Sapwood.-From one to several inches in width.

Heartwood.-Light to moderately dark yellowish brown with a greenish tinge.

Physical properties.-The wood is moderately light, straight-grained, and without characteristic odor or taste. 


\section{Similiar Woods.}

Yellow poplar can usually be distinguished from other woods by its greenish tinge, although in this respect it resembles cucumber, from which it can not always be distinguished without a compound microscope.

CUCUMBer-Tree (Magnolia acuminata Linn.), also known as mountain magnolia, is occassionally used for ties. Itis related to yellow poplar, which it resembles very much, although the yellow poplar averages lighter in weight. This difference in weight is not sufficient to be used for identification purposes; for the heavier grades of yellow poplar weigh more per cubic foot than the lighter grades of cucumber. The rays are slightly less conspicuous in cucumber-tree, but this feature can be observed only by comparing pieces of wood of the two species. In Sweer Magnolia, or sweet bay (Magnolia glauca Linn.), the rays are more conspicuous than in cucumber-tree or even yellow poplar, although in other respects the sweet magnolia wood resembles these species closely.

Cucumber-tree is found in about the same region as yellow poplar, except that it does not extend into Florida and the southeastern half of Georgia, South Carolina, North Carolina, and Virginia.

Sweet magnolia is found approximately in the territory southeast of a curve drawn from New York through central Kentucky to Galveston, Tex., excepting southern Florida.

\section{BASSWOOD.}

Other Names.

Tilia americana Linn.

Linden; linn; bass; limetree; whitewood; beetree.

Geographic Distribution.

See map, page 20.

Distinguishing Characteristics.

Pores.-Very small but distinctly visible with a lens; decreasing gradually in number and size toward the outer portion of each annual ring; numerous, occupying from one-third to one-half of the total area between the rays, except in very wide rings; isolated or in elongated or rounded groups of from two to eight, the groups extending radially, diagonally, or tangentially within the annual ring.

Rays.-Fairly distinct to the unaided eye; conspicuous under a lens; slightly narrower than the pores.

Parenchyma.-Usually not noticeable with a hand lens but occasionally visible as very fine tangential lines.

Annual rings.-Fairly distinct; defined by a slight but abrupt difference in the size of the pores of the summerwood and succeeding springwood. Pith flecks are occasionally present but are of about the same color as the surrounding wood and therefore not conspicuous.

Sapwood.-Creamy white, up to several inches in width, passing more or less gradually into the heartwood.

Heartwood.-Creamy brown in color, with occasional brownish-black longitudinal streaks.

Physical properties.-The wood is light, soft, straight-grained, and tasteless, but has a slight characteristic odor.

Similar Woods.

Other light woods, such as yellow poplar, cottonwood, buckeye, and cotton gum are occasionally confused with basswood; but the soft and almost white character of the wood and the irregular arrangement of the pores in diagonal and even tangential groups, together with the very distinct rays under a lens, help to distinguish it from these somewhat similar woods. 


\section{YELLOW BUCKEYE.}

Other Names.

Esculus octandra Marsh.

Large buckeye; big buckeye; sweet buckeye.

Geographic Distribution.

See map, page 30.

Distinguishing Characteristics.

Pores.-Very small, uniform in size and evenly distributed throughout the annual ring; isolated, or occasionally in short radial rows of from two to five; numerous, occupying from one-third to fully one-half of the area between the rays.

Rays.-Very fine, even under a lens; arranged in tiers producing very fine bands running across the tangential surface. These bands are visible without a lens, but are not pronounced near the center of the tree.

Parenchyma.-Not noticeable.

Annual rings.-Not always distinct; defined by light-colored lines.

Sapwood.-Not clearly defined from the heartwood.

Heartwood.-Creamy white or yellowish in color; occasionally discolored to a grayish brown at the center.

Physical properties. - The wood is light, soft, straight-grained, and without characteristic odor or taste.

Similar Woods.

Yellow buckeye resembles basswood very much; but under a lens the rays in the latter are much more conspicuous, and the fine lines across the tangential surface of buckeye distinguish it from basswood and other light woods.

Оніо BucKeye (Eesculus glabra Willd.), also known as fetid buckeye, stinking buckeye, and American horse chestnut, is very much like the yellow buckeye in appearance and properties, and grows in practically the same region. The fine lines across the tangential surface are not so pronounced in this species, although they are noticeable, especially on a moistened surface several inches from the center.

\section{DESCRIPTION OF CONIFERS.}

\section{THE PINES.}

About 36 species of pines are native to the United States, but only 13 are used for ties in commercial quantities, although others may be used locally. Pine ties are rarely mistaken for any other wood, nor are other species easily confused with pine.

The wood of the pines contains more or less pitch which usually exudes from cuts made before it is seasoned. The resinous odor and the presence of resin ducts (see p. 7) are also characteristic of the pines. The resin ducts can be seen plainly with a hand lens, and often without a lens, on a smoothly cut end surface. They are also found in Douglas fir, spruce, and larch or tamarack, but in these woods they are not so distinct and numerous as in the pines. Normally, resin ducts are not found in the wood of any other conifers.

The heartwood of the pines is usually orange to reddish brown. In piñon and lodgepole pine the diffcrence in the color of the heartwood and the sapwood is not pronounced. 
The pines are easily divided by the character of the leaves and the structure of the wood into two groups, the soft pines and the hard, yellow, or pitch pines.

In the soft pines there is little contrast botween the springwood and summerwood; in the hard pines there is a decided difference, the summerwood being considerably harder and darker, although in the narrow annual rings of the sapwood of old trees, the contrast is not so marked as in wider rings. The wood of the heavier species of the soft pines, however, weighs more per cubic foot than that of the lighter hard pines.

Two hard pines, lodgepole and western yellow, furnish abundant tie material in the Western States. In the East at least seven different species of hard pines are used for ties, but so far no means of distinguishing absolutely between all of them without a high-power microscope has been found. Each species varies in weight, width of annual rings, percentage of summerwood, and thickness of sapwood, so that no sharp distinction can be made on these bases. The following figures give the average weight in pounds per cubic foot oven-dry based on green volume, for each species: Norway, 28; pitch, 29; shortleaf, 31 ; loblolly, 31 ; pond, 31; longleaf, 34 ; slash, 36. However, heavy grades of Norway pine weigh more than light grades of loblolly, and some shortleaf pine is heavier than the average longleaf. The annual rings and the sapwood of Norway and loblolly pine average wider than those of longleaf, but in individual pieces the reverse may be true.

For means of distinguishing longleaf from loblolly and shortleaf pine ties and timbers which contain the pith see Appendix, page 73 .

Numerous tests made at the Forest Products Laboratory have shown that density, as indicated by the number of rings per inch and the proportion of summerwood, is a far better indication of strength than species.

It is a well-established fact that untreated ties with wide sapwood are less durable than those with narrow sapwood. This feature can be judged irrespective of species.

\section{WESTERN WHITE PINE.}

Other Names.

Pinus monticola Dougl.

Idaho white pine; silver pine; finger-cone pine; mountain pine; soft pine; white pine.

Geographic Distribution.

See map, page 3\%.

Distinguishing Characteristics.

Resin ducts.-Present; the openings are plainly visible with a lens and, under favorable conditions, even without a lens. The ducts are scattered promiscuously throughout the annual ring. 
Rays.-Mostly very fine, some (containing horizontal resin ducts) slightly wider and more conspicuous under a lens.

Annual rings.-Distinct, moderate in width, the soft springwood passing very gradually into the slightly harder and darker summerwood, which does not offer appreciably more resistance in cutting than the springwood.

Sapwood.-Mostly from 1 to 2 inches in width, occasionally 3 inches.

Heartwood.-Cream to light reddish brown.

Physical properties.-The wood is moderately light, straight-grained, and pract: cally tasteless, but has a slight, yet distinct, resinous odor.

Similar Woods.

The wood of the eastern White Pine (Pinus strobus Linn.) resembles that of the western white pine so much that the two can not be distinguished, and the above description may be applied to both species. The eastern white pine, however, is rarely cut into ties.

Limber pine averages slightly heavier in weight, but light grades are easily confused with the western white pine. The yellow pines have more pronounced summerwood, and therefore have more uneven texture; and the spruces differ in not having a distinctly darker heartwood.

\section{LIMBER PINE.}

Other Names.

Pinus flexilis James.

White pine; Rocky Mountain white pine.

Geographic Distribution.

See map, page 32.

Distinguishing Characteristics.

Resin ducts.-Present; occasionally easily detected by slight exudations of resin; evenly distributed or confined to summerwood, if the summerwood is wide.

Rays.-Mostly very fine; a few (those with horizontal resin ducts) slightly wider and more conspicuous under a lens.

Annual rings.-Mostly narrow, occasionally moderately wide; the summerwood may be thick in wide rings, but in contrast to the summerwood of the hard pines it is not dense enough to be much more difficult to cut than the springwood.

Sapwood.-Highly variable, from one-fourth inch to 3 inches in width.

Heartwood.-Reddish brown.

Physical properties.-The wood is somewhat heavier and harder than that of the other white pines and, as a rule, contains more knots, because it comes from shortbodied timber.

Similar Woods.

The light grades of limber pine resemble the western white pine, from which they are not readily distinguished.

Bristle-cone Pine (Pinus aristata Engelm.) is found at high elevations from central Colorado to eastern California and extends southward into northern Arizona and New Mexico. The wood resembles closely that of the limber pine in weight, grain, narrowness of rings, and abundance of knots; but the tangential surface of bristlecone pine shows numerous slight depressions, especially on split surfaces, giving the wood a dimpled appearance similar to that of lodgepole pine.

\section{PIÑON (PINE).}

Other Names.

Pinus edulis Engelm.

Nut pine; New Mexican piñon.

Geographic Distribution.

See map, page 32 . 
Distinguishing Characteristics.

Resin ducts.--Present, scattered throughout the annual ring; openings not visible without a lens, and appearing as tiny specks to the unaided eye.

Rays.-Mostly very fine, a few (those containing horizontal resin ducts) slightly wider and more conspicuous under a lens.

Annual rings.-Mostly very narrow, not always distinct even with a hand lens.

Sapwood.-From one-half inch to $1 \frac{1}{2}$ inches wide; boundary between sapwood and heartwood not clearly defined.

Heartwood.-Creamy brown, occasionally with a slight reddish tinge.

Physical properties.-The piñon is the heaviest of the soft pine group, some pieces weighing over 40 pounds per cubic foot oven-dry. It is somewhat cross-grained, very knotty, and difficult to split. The wood is practically odorless and tasteless.

Similar Woods.

The pale, creamy brown color and the absence of dense bands of summerwood alternating with soft bands of springwood distinguish piñon from the yellow pines, with which it might otherwise be confused on account of its weight. The other pines belonging to the soft-pine group are lighter in weight, softer, and have more of a reddish brown color.

\section{LODGEPOLE PINE.}

\section{Other Names.}

\section{Pinus contorta Loud.}

Scrub pine; bird's-eye pine; tamarack; sand pine (Oreg.). Geographic Distribution.

See map, page 32.

Distinguishing Characteristics.

Resin ducts.-Present; fairly numerous; not distinctly visible without a lens, but often indicated by exudations of resin.

Rays.-Very fine, except occasional ones (containing horizontal resin ducts) which are quite distinct under a lens.

Annual rings.-Distinct; moderately wide at the center, but soon becoming narrow; summerwood well defined as a darker but narrow band, usually not noticeably hard in cutting across the grain.

Sapwood.-Mostly about an inch wide, rarely up to $2 \frac{1}{2}$ inches.

IIeartwood.-Only slightly darker than the sapwood and often not clearly defined.

Physical properties.-The wood is one of the lightest of the yellow pines, averaging about 24 pounds per cubic foot, oven-dry, based on green volume. It is usually straight-grained but contains numerous knots near the center. The wood is practically tasteless, but has a resinous odor when fresh.

On the surface under the bark or on split tangential surfaces numerous slight indentations may be seen, which give the surface a dimpled or "bird's-eye" appearance.

Similar Woods.

Western yellow pine resembles lodgepole somewhat, but has darker and more distinct heartwood, wider sapwood, larger resin ducts, and only rarely does the tangential surface show the slight indentations so characteristic of lodgepole pine. Bristlecone pine shows the same indentations, but has a distinct reddish brown heartwood and usually very narrow annual rings even near the center. Engelmann spruce also resembles lodgepole pine in general appearance but is entirely without the "bird'seye" grain.

\section{WESTERN YELLOW PINE.}

\section{Other Names.}

Pinus ponderosa Laws.

Bull pine (young vigorous trees); big pine; red pine: pitch pine; western pine; white pine (lumber) 


\section{Geographic Distribution.}

See map, page 32.

Distinguishing Characteristics.

Resin ducts.-Present; comparatively large, the opening usually distinctly visible without a lens; confined to the outer half of the annual ring.

Rays.- Mostly very fine, a few (containing the horizontal resin ducts) are wider and more distinct under a lens.

Annual rings.-Moderately wide in the heartwood, but very narrow in the outer sapwood of old trees; the summerwood conspicuous in wide rings but reduced in narrow rings to a thin layer not distinct without a lens. (The sapwood of western yellow pine approximates white pine in appearance.)

Sapwood.-Clearly defined, averaging from $2 \frac{1}{2}$ to 4 inches in width.

Heartwood.-Light reddish brown.

Physical properties.-The wood is one of the lightest of the yellow pines, averaging about 24 pounds per cubic foot air-dry. It is straight-grained and tasteless, but has a slight resinous odor. Occasional trees (especially in the Southwest) show numerous slight depressions on the tangential surface of the wood, giving it a dimpled or "bird'seye" appearance.

Similar Woods.

Pieces of western yellow pine with the "bird's-eye" grain resemble lodgepole; but western yellow pine has darker heartwood, wider sapwood, and more distinct resin ducts. Lodgepole pine does not attain as large size as the western yellow pine; therefore, the annual rings in lodgepole are usually very narrow (from 20 to 30 per inch) beyond the fourth or fifth inch from the center, while in western yellow pine they usually continue wider (from 5 to 20 per inch) until beyond the seventh or eighth inch from the center. Exceptions, however, are found and identification can not be based on the width of the rings alone.

The distinct bands of summerwood, particularly noticeable in the heartwood, distinguish western yellow pine from the white pines; and its light weight and comparatively large resin ducts help to distinguish it from the eastern yellow pines.

\section{NORWAY PINE.}

Other Name.

Pinus resinosa Ait.

\section{Red pine.}

Geographic Distribution.

See map, page 32.

Distinguishing Characteristics.

Resin ducts.-Present; mostly in outer half of annual ring, but occasionally in inner half; openings not visible without a lens.

Rays.-Mostly very fine, occasional ones (containing horizontal resin ducts) wider and more distinct with the aid of a lens.

Annual rings.-Fairly wide; the summerwood distinct as a narrow, harder, and darker band, but not offering much resistence to cutting across the grain, except in very wide rings.

Sapwood.-From 2 to 4 inches in width.

Heartwood.-In various shades of reddish brown.

Physical properties.-The wood is the lightest of the hard pines east of the Mississippi River, averaging about 28 pounds per cubic foot, oven-dry, based on green volume. It is usually straight-grained and is practically tasteless, but has a slight resinous odor.

Similar Woods.

Norway pine resembles the iighter grades of the southern yellow pines to such an extent that it is difficult to find any features to distinguish these species. Since 
Norway pine is found only in the Northern States and Canada, its origin is usually enough to identify it, although in New York, Pennsylvania, and the southern New England States it grows in mixture with pitch pine (Pinus rigida Mill.), from which the wood is not easily distinguished, although pitch pine is harder, more resinous, and contains more knots.

Norway pine is unique in that its cell structure is such that it can easily be distin. guished from all other native pines with the aid of a compound microscope.

\section{SHORTLEAF PINE.}

Other Names.

Pinus echinata Mill.

Yellow pine; spruce pine; bull pine; oldfield pine; rosemary pine (N. C.); Nortb Carolina yellow pine; slash pine.

Geographic Distribution.

See map, page 32.

Distinguishing Characteristics.

Resin ducts.-Present; scattered throughout the annual rings; comparative'y small, openings rarely visible without a lens.

Medullary rays.-Mostly very fine, although some (containing horizontal resin ducts) are wider and more distinct under a lens.

Annual rings.-Distinct, moderately wide to narrow, the summerwood conspicuous as a narrow, harder, and darker band.

Sapwood.-Mostly from 2 to 4 inches in width in ties.

Heartwood.-Yellowish to orange-brown.

Physical properties.-The wood is moderately heavy to heavy, straight-grained, and easily split. It is practically tasteless, but has a slight resinous odor.

Similar Woods.

Shortleaf pine averages between longleaf and loblolly in width of rings and thickness of sapwood. From pitch pine it can not easily be distinguished after it is cut into ties or other material. For a method of distinguishing between shortleaf and longleaf pine, see Appendix, page 73.

Pitch Pine (Pinus rigida Mill.), also known as hard pine, yellow pine, black pine, and black Norway pine, is found from southeastern Canada southward in the Atlantic and Appalachian region to central Georgia. The wood resembles that of shortleaf pine and weighs approximately the same.

\section{LOBLOLLY PINE.}

Other Names.

Pinus tæda Linn.

Oldfield pine; slash pine; bull pine; bastard pine; swamp pine; rosemary pine; torch pine; shortleaf pine; sap pine.

Geographic Distribution.

See map, page 32 .

Distinguishing Characteristics.

Resin ducts.-Present; scattered throughout the annual ring; openings rarely visible without a lens.

Medullary rays.-Mostly very fine, but occasionally some (containing horizontal resin ducts) slightly wider and more distinct under a lens.

Annual rings.-Distinct; mostly wide even at 6 inches or more from the center, but occasionally narrow and then producing what is known as "rosemary pine"; the summerwood variable from moderately hard in very wide rings to very hard and dense in rings of moderate width.

Sapwood.-Mostly from 3 to 5 inches in width in ties.

Heartwood.-Yellowish to orange-brown. 
Physical properties. - The wood is highly variable in weight, but averages about 31 pounds per cubic foot, oven-dry, based on green volume. It is straight-grained, easily split, and has a resinous odor.

Similar Woods.

The other southern pines commonly have narrower rings and thinner sapwood than loblolly pine, but exceptions are often found, so that these features can not be used for identification. For distinguishing loblolly and longleaf pine see Appendix, page 73 .

Pond Pine (Pinus serotina Michx.), also known as marsh pine, meadow pine, loblolly pine, spruce pine, bastard pine, and bull pine, is found in low places ("ponds") along the Atlantic coast from southeastern Virginia to central Alabama, not including the lower half of the Florida Peninsula. When cut into ties or timbers it is marketed as either longleaf or shortleaf pine. No definite distinction between the wood of pond pine and that of the other southern pines has yet been found.

\section{LONGLEAF PINE.}

Other Names.

\section{Pinus palustris Mill.}

Southern yellow pine; yellow pine; turpentine pine; rosemary pine; hard pine; Georgia pine; fat pine; southern pitch pine; heart pine; longstraw pine; pitch pine. Geographic Distribution.

See map, page 32.

Distinguishing Characteristirs.

Resin ducts.-Present; numerous; scattered throughout the annual ring; comparatively large, the openings often visible to the unaided eye.

Rays.-Mostly very narrow, a few (those containing horizontal resin ducts) wider and more distinct under a lens.

Annual rings.-Very distinct; mostly narrow, especially several inches from the center; often irregular in width; the summerwood comparatively wide; often occupying one-half the annual ring.

Sapwood.-Mostly between 1 and 2 inches in width in ties, occasionally more or less.

Heartwood.-Yellowish to orange-brown.

Physical properties.-The wood is heavy and hard, straight-grained, and has a distinct resinous odor.

Similar Woods.

Although the annual rings and sapwood in longleaf pine average narrower than in the other southern pires, these features are more or less variable and can not be relied upon for identification.

For a method of distinguishing longleaf from loblolly and shortleaf pines see Appendix, page 73 .

Slash PINE (Pinus heterophylla (Ell.) Sudworth), also known as swamp pine, Cuban pine, and bastard pine, is found only in the coast region from southern South Carolina to Louisiana (St. Tammany and Washington Parishes), including practically all of Florida. It resembles longleaf pine in being dense and hard, but on the average it has wider sapwood and wider and more irregular annual rings.

\section{ENGELMANN SPRUCE.}

Other Names.

\section{Picea engelmanni Engelm.}

White spruce; mountain spruce (Mont.); balsam (Utah).

Geographic Distribution.

See map, page 34 .

Distinguishing Characteristics.

Resin ducts.-Present; comparatively few; mostly isolated, less frequently two adjacent, and occasionally many in a tangential row; inconspicuous, easily overlooked.

$$
96625^{\circ}-17-5
$$


often visible only as white specks in the summerwood, their presence also indicated by occasional wider medullary rays which contain the horizontal resin ducts.

Rays.-Very fine, except as indicated above.

Annual rings.-Moderate in width; summerwood narrow, not much denser or darker than the springwood; transition from springwood to summerwood gradual.

Sapwood.-Not distinctly defined, but noticeable on green timbers because of its higher moisture content; variable from three-fourths of an inch to 2 inches in width.

Heartwood.-Pale yellowish brown.

Physical properties.-The wood is light and straight-grained. It has no characteristic odor or taste.

Similar Woods.

Engelmann spruce is easily confused with Alpine fir, white fir, and lodgepole pine, which also have almost white heartwood. In the true firs, however, resin ducts are normally absent. Lodgepole pine has a dimpled surface under the bark cr when split tangentially, a feature not found in Engelmann spruce.

The White Spruce (Picea canadensis (Mill.) B. S. P.) found in the Lake States, New England States, and Appalachian Mountains, and the Red Spruce (Picec rubens Sargent) found in the New England States and Appalachian Mountains have practically the same structure as the Engelmann spruce, although the wood is slightly heavier and stronger, but they are rarely used for ties or timbers.

\section{DOUGLAS FIR.}

Other Names.

\section{Pseudotsuga taxifolia (Lam.) Britton.}

Douglas spruce; red fir; yellow fir; fir; Oregon pine; spruce (Mont.); red pine; Puget Sound pine.

Geographic Distribution.

See map, page 30 .

Distinguishing Characteristics.

Resin ducts.-Present; small and inconspicuous; occasionally visible without a lens as elongated whitish specks, especially in the summerwood; the openings not visible without a lens; often in tangential rows of from 2 to 20 or more.

Rays.-Mostly very fine, a few (containing horizontal resin ducts) slightly wider and more conspicuous under a lens.

Annual rings.--Very distinct; variable from narrow to wide; summerwood always conspicuous as a denser and darker band but variable from very narrow in slow growth to wide and hard in trees of rapid growth.

Sapwood.-About 1 inch wide in Rocky Mountain forms, and several inches wide in Pacific coast forms.

Heartwood.-Mostly orange-reddish to red, the springwood as well as the summerwood being colored; sometimes yellowish in old Pacific coast trees.

Physical properties.-The wood is variable in weight, from moderately heavy to heavy, fairly straight grained, and practically tasteless, but has a distinct odor when fresh.

Similar Wood3.

Douglas fir is not one of the true firs (Abies), of which balsam fir, alpine fir, white fir, and noble fir are representatives. It differs from these in being heavier and stronger, in having a distinct and darker heartwood, and in containing resin ducts. Neither is it a spruce (Picea) nor a pine (Pinus), although the names "Douglas spruce" and "Oregon pine" are applied to it.

The wood resembles that of the larch and hard pines, although a distinct reddish hue is characteristic of Douglas fir only. The larch has a russet-brown heartwood and comparatively narrow sapwood. The hard pines have a yellowish or orangebrown heartwood and usually irregular growth rings. The resin ducts in larch are 
also often grouped and inconspicuous, like those in Douglas fir, but in the pines they are larger and more numerous and not in groups.

If parts of the bark are present, the thin whitish layers alternating with wider, dark reddish-brown layers form an excellent means of identification; for none of the other species with which Douglas fir might be confused have developed these lighter colored layers.

\section{WESTERN LARCH.}

Other Names.

Larix occidentalis Nutt.

Tamarack; hackmatack.

Geographic Distribution.

See map, page 34.

Distinguishing Characteristics.

Resin ducts.-Present; not numerous; scattered singly or in short tangential rows; inconspicuous even with a lens; their presence also indicated by occasional wider medullary rays, which contain the horizontal resin ducts.

Rays.-Very fine, except as stated above; distinct on radial surface because darker. Annual rings.-Mostly very narrow, but the summerwood always distinct as a denser band.

Sapwood.-Narrow, mostly from one-half to three-fourths of an inch, rarely over 1 inch wide.

Heartwood.-Russet to reddish brown.

Physical properties.-The wood is moderately heavy, relatively narrow-ringed, and not slivery. It has no characteristic odor or taste.

Similar Woods.

Western larch shows more resemblance to Douglas fir than to any other wood with which it is associated. However, it has a distinctly brownish heartwood and narrow sapwood as contrasted with the reddish or yellowish heartwood and wider sapwood of Douglas fir. The hard pines have much wider sapwood and are more resinous.

The eastern larch or tamarack has wider rings with wider summerwood, and is more slivery. On account of the difference in the geographic distribution of these two species it is rarely necessary to distinguish between them.

\section{TAMARACK.}

Other Names.

\section{Larix laricina (Du Roi) Koch.}

Larch; eastern larch; hackmatack; juniper (Maine, New Brunswick, to Hudson Bay).

Geographic Distribution.

See map, page 34 .

Distinguishing Characteristics.

Resin ducts.-Present; not numerous; scattered singly, or several in a tangential row; inconspicuous, easily overlooked even with a lens; their presence also indicated by occasional wider medullary rays, which contain the horizontal ducts.

Rays.-Very fine except as stated above.

Annual rings.-Moderately wide, the summerwood conspicuous as a dense hard band.

Sapwood.-Mostly less than an inch wide.

Heartwood.-Yellowish brown to russet brown without reddish tinge.

Physical properties.-The wood is heavy, coarse, and slivery. It has no distinct odor or taste.

Similar Woods.

Since the tamarack is found only east of the prairies, there is little possibility of its being confused with the western larch and Douglas fir, which it resembles. It is also similar to hemlock in being coarse and splintery, but the tamarack lacks the reddish 
hue of hemlock, and has a decided contrast between heartwood and sapwood. The hard pines have wider sapwood and are more resinous, as is indicated by the odor or abundant exudations of resin. On carefully comparing the woods under a lens it will be found that hemlock has no resin ducts, and that in the pines the resin ducts are more distinct and numerous than in tamarack.

\section{PORT ORFORD CEDAR.}

\section{Other Names.}

Chamæcyparis lawsoniana (Murr.) Parl.

Lawson cypress; Oregon cedar; white cedar; ginger pine.

Geographic Distribution.

See map, page 30.

Distinguishing Characteristics.

Resin ducts.-Absent.

Rays.-Very narrow; uniform in width; inconspicuous.

Annual rings.-Distinct but not prominent; moderate in width; the summerwood only slightly denser than the springwood.

Sapwood.-Narrow, from 1 to 3 inches in width; not always clearly distinguishable from the heartwood.

Heartwood.-Pale brown.

Physical properties.-The wood is moderately light, straight-grained, and easily worked. It has a pronounced spicy odor and taste, which readily distinguish it from other species. The summerwood is not dense and hard as in many coniferous woods; therefore it has an unusually uniform structure, which makes it desirable for a great many purposes. This fact and its local distribution make the amount available for ties comparatively small.

Similar Woods.

Port Orford Cedar resembles the other cedars somewhat, but the light-colored heartwood and characteristic spicy odor afford an easy means of identification.

\section{WHITE FIR.}

\section{Other Names.}

$$
\text { Abies concolor (Gord.) Parry. }
$$

Balsam fir; balsam; white balsam; silver fir.

Geographic Distribution.

See map, page 34.

Distinguishing Characteristics.

Resin ducts.-Normally absent; occasionally present in the outer summerwood in the form of tangential rows, from one-eighth of an inch to an inch or more in length. (Plate XXVIII, fig. 2, shows a row of abnormal resin ducts.)

Rays.-Very fine and of uniform width.

Annual rings.-Mostly moderately wide, showing fairly rapid growth; the comparatively wide and almost white springwood passes gradually into the narrow, darker, and harder summerwood.

Sapwood.-Not distinguishable from the heartwood.

Heartwood.-White or with a reddish brown tinge due to darker bands of summerwood.

Physical properties.-The wood is moderately light, straight-grained, and without characteristic odor or taste.

Similar Woods.

White fir resembles alpine fir, but the alpine fir usually has narrower rings and a distinct disagreeable odor. It is lighter in color, especially in the springwood, than the noble fir and hemlocks. It can not be distinguished from grand fir, unless a por. 
tion of the bark half an inch or more in thickness is present. White fir has narrow white layers in the outer bark; while grand fir, noble fir, and the hemlocks have thin very dark brown layers in the outer bark. Alpine fir has too thin a bark on tie material to have developed these layers.

Alpine Fir (Abies lasiocarpa (Hook.) Nutt.), also known as balsam, white fir, mountain balsam, and downy-cone fir grows throughout the high mountain slopes from Arizona to Montana and Idaho, westward through northern Oregon, and northward to Alaska. The wood is the lightest of the western firs and, being almost white in color, closely resembles that of the white fir; but the annual rings are usually narrower, though trees with rings of moderate width are occasionally found. The summerwood is not very pronounced and does not offer appreciably more resistance in cutting across the grain than the springwood. The wood has a mild but distinct rank odor, noticeable especially when fresh cuts are made on dry wood. Except for this odor, it would often be impossible to distinguish alpine fir from some of the other firs, particularly white fir.

\section{GRAND FIR.}

Other Names.

\section{Abies grandis Lindl.}

White fir; lowland fir; silver fir; yellow fir; great California fir.

Geographic Distribution.

See map, page 20.

Distinguishing Characteristics.

Resin ducts.-Absent, or occasionally present in the form of tangential rows of from one-eighth of an inch to over an inch long.

Rays.-Very fine and of uniform size.

Annual rings.-Usually fairly wide, showing rapid growth; the springwood, soft and almost white, passing gradually into the narrow but conspicuously darker and harder summerwood.

Sapwood.-Not distinguishable from the heartwood.

Heartwood.-White, with a reddish brown tinge, which is more pronounced in pieces of slow growth.

Physicai properties. - The wood is moderately light, straight-grained, and without characteristic odor or taste.

Similar Woods.

Grand fir is not easily distinguished from the other firs except alpine fir, which has a disagreeable odor when cut. On the average, grand fir has a more nearly white springwood and wider rings than the noble fir, but specimens showing narrow rings may also be found.

Noble FIr (Abies nobilis Lindl.), also known as red fir, larch, bigtree, feather-cone red fir, and bracted red fir, is found only in Oregon and Washington. It has the same general characteristics as the other firs. The wood has somewhat of a reddish tinge, which is due to the pale reddish springwood and the slow growth, which brings the darker bands of summerwood close together. It thus resembles western hemlock, from which it is not easily distinguished without a compound microscope. Specimens of rapid growth resemble normal grand fir very closely. The wood is moderately light, straight-grained, and without distinct odor or taste.

\section{EASTERN HEMLOCK.}

Other Names.

Tsuga canadensis (Linn.) Carr.

Hemlock spruce; spruce pine

Geographic Distribution.

See map, page 34 . 


\section{Distinguishing Characteristics.}

Resin ducts.-Absent.

Rays.-Very fine and of uniform width throughout.

Annual rings.-Narrow to moderately wide; the springwood soft and with a reddish hue and passing gradually into the narrow, harder, and darker summerwood.

Sapwood.-Usually not distinct from the heartwood, occasionally slightly lighter in color.

Heartwood.-Pale brown with a reddish hue.

Physical properties.-The wood is moderately light, straight-grained or twisted, and practically tasteless and odorless or with a sour odor when fresh. Cup shake is a common defect.

Similar Woods.

Hemlock is similar to the spruces and true firs in that the heartwood is not distinctly darker than the sapwood. Spruce, however, is lighter in color, weighs less, is not so slivery, and has resin ducts. The resin ducts can be seen only under a lens, but are often indicated by exudations of resin. Most of the firs also are of a lighter color than hemlock, especially in the springwood of each annual ring, and not so splintery. Noble fir, however, resembles hemlock so much in weight, color, and general appearance that they can not be distinguished easily without a compound microscope.

Western Hemlock (Tsuga heterophylla (Raf.) Sargent), also known as Alaska fir, Alaska pine, and gray fir, has the same general structure as the eastern hemlock; but the wood is less splintery, and usually free from cup shake. Abnormal resin passages are often present, forming tangential rows in the outer portion of the summerwood. This feature is also found in some of the true firs but not in the eastern hemlock. For geographic distribution see map, page 34 .

\section{REDWOOD.}

Other Name.

$$
\text { Sequoia sempervirens (Lamb.) Endl. }
$$

\section{Sequoia.}

Geographic Distribution.

See map, page 20.

Distinguishing Characteristics.

Resin ducts.-Normally absent, present only as result of injury and then in a tangential line at point of injury only.

Rays.-Narrow; uniform in width; easily visible with a lens because lighter colored than the surrounding wood.

Annual rings.-Moderate and regular in width; very distinct because of the summerwood, which is more pronounced than in the cedars. The dark specks in the illustration in Plate XXX, fig. 1, are cells containing resin ("resin cells") which are numerous in this species but, on account of the dark color of the wood, are not easily seen on the end surface. On split surfaces the resin cells are often quite distinct under a lens, appearing as dark lines running with the grain.

Sapwood.-One to several inches in width; almost white.

Heartwood.-Uniform deep reddish brown.

Physical properties.-The wood is moderately light, straight-grained, rarely wavygrained, and splits easily. It has no characteristic odor or taste.

Similar Woods.

Redwood is not easily confused with any other wood. In color it somewhat resembles the junipers and dark grades of western red cedar. The junipers are much finer textured, have a distinct agreeable odor, and are rarely used for ties. The cedars have an aromatic odor and bitter taste. 


\section{BALD CYPRESS.}

Other Names.

Taxodium distichum (Linn.) Rich.

Cypress; swamp cypress; white cypress; yellow cypress; red cypress; black cypress; southern cypress.

Geographic Distribution.

See map, page 34 .

Distinguishing Characteristics.

Resin ducts.-Absent.

Rays.-Uniformly narrow.

Annual rings.-Distinct; usually irregular in width and outline; the summerwood very noticeable as a dense, dark band, or inconspicuous in lighter grades. The dark specks in the illustration in Pl. XXX, fig. 2, are cells containing resin ("resin cells"). They are abundant in this species and can be seen with a hand lens, especially in light-colored grades. The resin cells are usually arranged in irregular tangential bands. On a split surface they are very distinct under a lens, appearing as dark lines running with the grain.

Sapwood.-Usually over an inch in width, passing more or less gradually into the heartwood.

Heartwood.-Highly variable in color from pale brown to blackish brown, sometimes with a reddish tinge.

Physical properties.-The wood varies in weight from moderately light to heavy, and averages about 26 pounds per cubic foot oven-dry. It is usually straight-grained and easily split. The odor is characteristic and may be described as rancid, although one must become familiar with it to be able to recognize it. The longitudinal surfaces feel distinctly greasy, or waxy, especially in the darker grades.

Similar Woods.

Cypress varies as much as any of our native woods in color and weight and therefore is often difficult to identify by these features. It resembles the cedars more than other woods, but the odor is entirely different. Cypress is practically tasteless, while the heartwood of the cedars is distinctly spicy or bitter. Only one species of bald cypress is found in the United States; but several grades, such as "white," "yellow," "red," and "black cypress," are known on the market, the grades being based on color and weight. Certain species (Cupressus sp.) in the western part of the United States are also known as cypress, but they are of minor commercial importance and are not closely related to the southern bald cypress.

\section{WESTERN RED CEDAR.}

Other Names.

\section{Thuja plicata Don.}

Canoe cedar; arborvitæ; giant arborvitæ; shinglewood; gigantic cedar; Pacific red cedar.

Geographic Distribution.

See map, page 30.

Distinguishing Characteristics.

Resin ducts.-Absent.

Rays.-Very narrow and inconspicuous; uniform in width.

Annual rings.-Distinct; moderately narrow; with a thin but dense band of summerwood.

Sapwood.-Fron one-fourth inch to 1 inch in width.

Heartwood.-Brown, usually with a reddish hue.

Physical properties.--The wood is light, straight-grained, and easily split. It has a distinct odor characteristic of cedar shingles, and the heartwood has a spicy bitter 
taste. The wood is not resinous, although globules of resin may exude from the bark. Similar Woods.

The western red cedar resembles most closely the arborvitæ; but since the two grow in regions widely separated they are not easily confused. The arborvitæ is of slower growth and has a plain light brown color usually without reddish tinge. Dark grades resemble redwood, but the redwood is without characteristic odor or taste.

\section{ARBORVITE (NORTHERN WHITE CEDAR).}

Other Names.

Thuja occidentalis Linn.

White cedar; cedar.

Geographic Distribution.

See map, page 34 .

Distinguishing Characteristics.

Resin ducts.-Absent.

Rays.-All very narrow and inconspicuous.

Annual rings. - Narrow but indistinct; the summerwood thin and not noticeable on cutting with a knife.

Sapwood.-Narrow; not over 1 inch in width except in some second-growth trees. Heartuood.-Light brown, rarely with a reddish tinge.

Physical properties.- The wood is very light, straight grained, soft, and easily split. It has the characteristic odor of the familiar cedar shingles, and the heartwood is somewhat bitter or spicy to the taste. The wood is not resinous, but globules of resin sometimes exude from the bark.

Similar Woods.

The arborvitæ resembles the western red cedar, but usually has narrower rings and is of a plain brown color without the reddish hue found in the western species. Cypress has a more dingy color and a rancid odor which in no way resembles the pleasant odor of the cedar.

White Cedak (Chamæcyparis thyoides (L.) B. S. P.), also known as swamp cedar and juniper, grows along the coast from Ma:ne to northern Florida and westward to Mississippi. It resembles arborvitæ, but has more of a pinkish hue, a spicy odor, and, as a rule, wider annual rings. 


\section{APPENDIX.}

\section{A METHOD OF DISTINGUISHING LONGLEAF FROM SHORTLEAF AND LOBLOLLY PINE TIES OR TIMBERS.}

The pith, which is the small darker and softer core at the structural center of the tree trunk, averages larger in longleaf than in shortleaf or loblolly pine. See figure 7 .

In longleaf pine the pith measures over 0.10 inch in diameter; in the other two species it is smaller (usually about the size of the lead in a lead pencil), except in pieces of vigorous growth, in which it may be as large as in longleaf.

The rigor of a tree at the time the pith was formed is indicated by the diameter of the second annual ring from outside to outside (which, of course, includes the first ring also).

Therefore, when the pith in loblolly and shortleaf is over $0.10 \mathrm{inch}$ in diameter the diameter of the second annual ring is comparatively large; in fact, it is larger than in longleaf having the same sized pith.

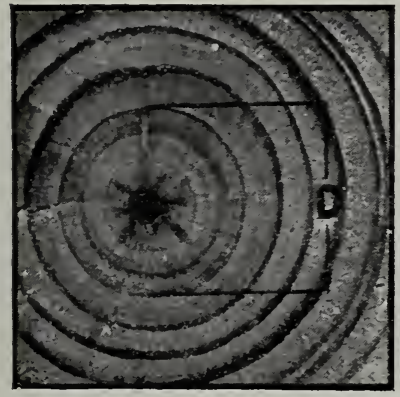

A.

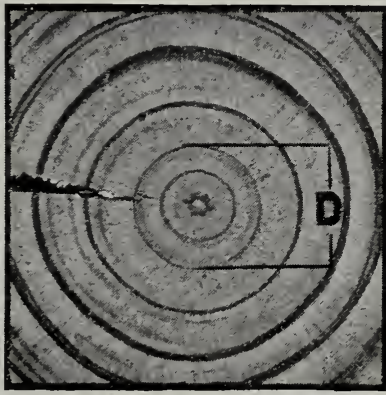

B.

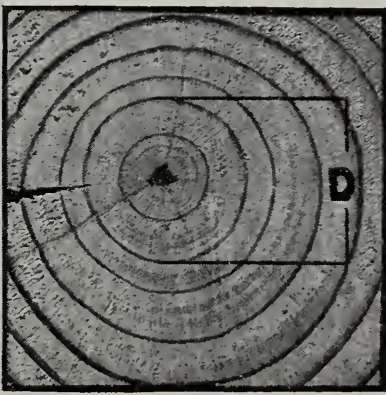

C.

FIG. 7.-A, longleaf; B, loblolly; C, shortleaf pine of moderate growth; showing pith (the dark core in the center) and diameter of second annual ring, D. All natural size.

This is shown in the accompanying diagram (fig. 8), in which are marked the points where the horizontal lines indicating the diameter of the pith intersect the vertical lines indicating the diameter of the second annual ring of numerous specimens. The line $A B$ is so drawn as to separate the points representing longleaf specimens from the points representing loblolly and shortleaf specimens.

HOW TO USE THE PITH AND SECOND ANNUAL RING FOR IDENTIFICATION.

1. With a sharp knife carefully smooth the end surface of the pith and surrounding wood.

2. If the pith or second annual ring is not clear, moisten the smoothed surface.

3. If knots are present near the pith, satisfactory measurements can not be made, and the other end of the timber should be inspected. 
4. If the pith is about the size of the lead in an ordinary lead pencil or smaller, the specimen is not longleaf, and no further measurement is necessary. See loblolly and shortleaf specimens, figure 7 .

5 . If the pith is plainly over 0.10 inch in diameter and the growth rings surrounding it very narrow, the specimen is longleaf or in rare instances slash or pond pine. See longleaf specimen in figure 7 .

6. If in doubt as to the species, carefully measure the average diameter of the pith, not including small projections, using a rule graduated in twenty-fifths or fiftieths of an inch. A reading glass or low-power hand lens is helpful but not essential in making these measurements.

7. Measure the diameter of the second annual ring in tenths of an inch. The first and second annual rings are usually very distinct, but in some pieces the first annual ring is rather faint, and care must

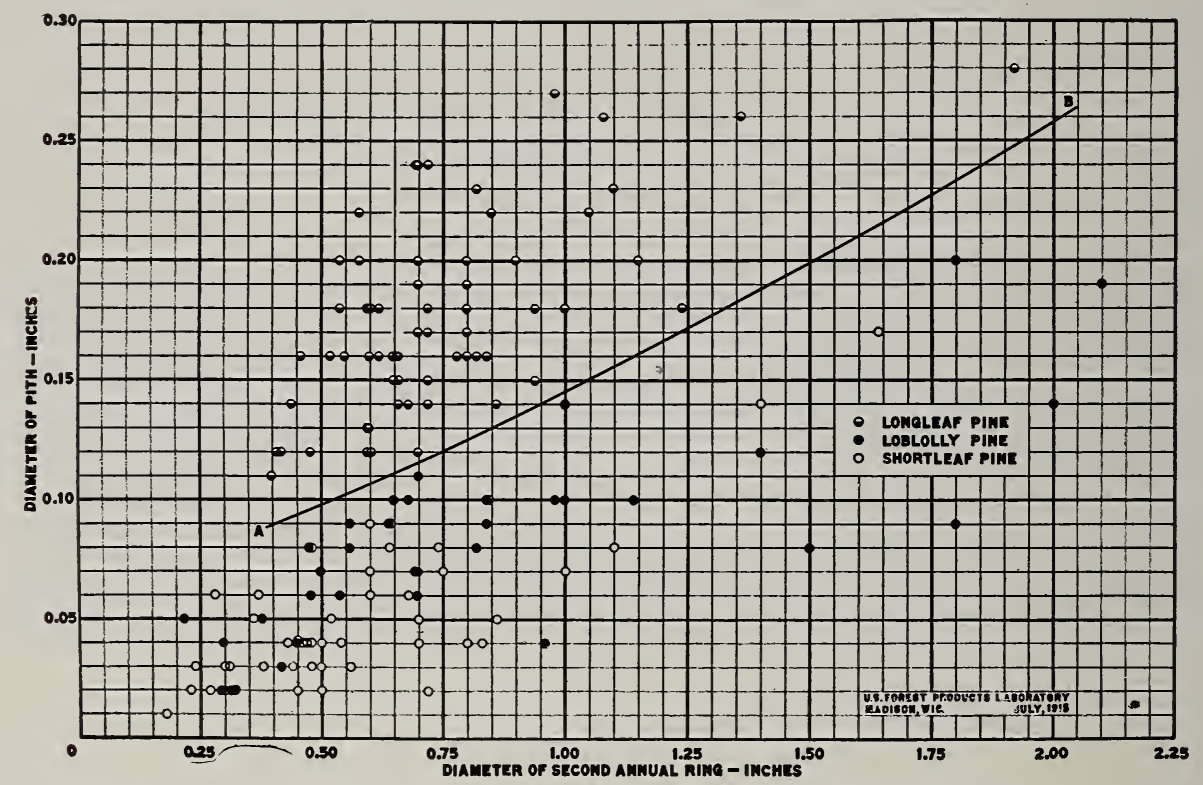

FIG. 8.-Diagram showing relation of diameter of pith to diameter of second annual ring in longleaf, loblolly, and shortleaf pine.

be taken not to mistake the third annual ring for the second. Sometimes false rings are present, but these can be recognized by the fact that they usually are not prominent all the way around, and their outer limit is not defined by a sharp line.

8. On the diagram (fig. 8) find the point where the vertical line which indicates the diameter of the pith intersects the horizontal line which indicates the diameter of the second annual ring.

9. If the point of intersection falls above the line $A B$, the tie is longleaf, or in rare instances it may be slash or pond pine; if it falls below the line, the tie is not longleaf but may be shortleaf, loblolly, or some of the other minor southern pines.

10. If the point of intersection falls close to the line $A B$, make measurements on the other end of the timber. 


\section{INDEX TO SCIENTIFIC NAMES.}

\begin{tabular}{|c|c|c|c|}
\hline \multicolumn{2}{|c|}{ Page. } & \multicolumn{2}{|c|}{ Page. } \\
\hline (n................... & 68 & Pinus edulis.......... & \\
\hline 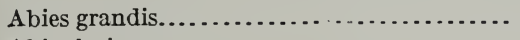 & 69 & Pinus flexilis......... & 61 \\
\hline 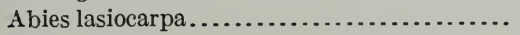 & 69 & Pinus heterophylla... & 65 \\
\hline Abies nobilis............ & 69 & Pinus monticola...... & 60 \\
\hline Acer rubrum ........... & 52 & Pinus palustris... & 65 \\
\hline Acer saccharinum. . & 51 & Pinus ponderosa... & 62 \\
\hline Acer saccharum......... & 51 & Pinus resinosa.. & 63 \\
\hline Aesculus glabra.......... & 59 & Pinus rigida.... & 64 \\
\hline Aesculus octandra...... & 59 & Pinus serotina....... & 65 \\
\hline Betula lenta............. & 54 & Pinus strobus....... & 61 \\
\hline etula lutea............ & 53 & Pinus taeda........ & 64 \\
\hline etula nigra............ & 54 & Platanus occidentalis. & 50 \\
\hline etula papyrifera....... & 54 & Populus deltoides... & 55 \\
\hline 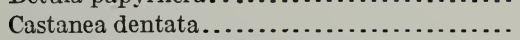 & 41 & (2)... & 55 \\
\hline Catalpa catalpa............... & 45 & (n) & 55 \\
\hline 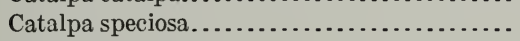 & 45 & (n) & 55 \\
\hline sissippiensis....................... & 43 & 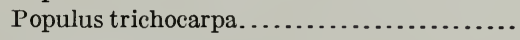 & 55 \\
\hline cidentalis. ...................... & 43 & 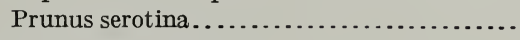 & 52 \\
\hline lawsoniana................. & 68 & Pseudotsuga taxifolia....................... & 66 \\
\hline 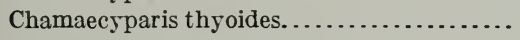 & 71 & 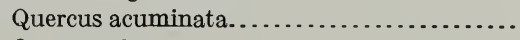 & 38 \\
\hline sus sp.................................. & 71 & (n.................. & 38 \\
\hline rginiana.. & 48 & Quercus catesbaei. . & 40 \\
\hline cea....... & 50 & Quercus coccinea.. & 40 \\
\hline icana.. & 46 & Quercus digitata... & 40 \\
\hline uus lanceolata...... & 47 & Quercus imbricaria. & 41 \\
\hline nigra ........... & 47 & Quercus laurifolia. . & 40 \\
\hline canthos....................... & 45 & Quercus lyrata...... & 38 \\
\hline iocladus dioicus........................ & 46 & Quercus macrocarpa. . . . . . . . . . . . & 38 \\
\hline 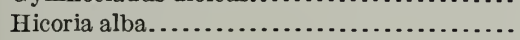 & 49 & narilandica. . . . . . . & 40 \\
\hline atica............................ & 49 & 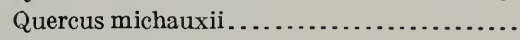 & 38 \\
\hline a. & 49 & 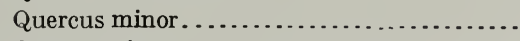 & 38 \\
\hline niosa............................. & 49 & is nigra....... & 40 \\
\hline 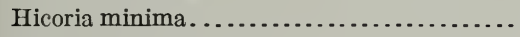 & 49 & s palustris.......................... & 40 \\
\hline ticaeformis. . . . . . . . & 49 & s........................... & 40 \\
\hline ovata.................. & 49 & platanoides........................ & 38 \\
\hline ecan.............. & 49 & 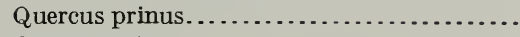 & 38 \\
\hline Juglans cinerea........................... & 53 & 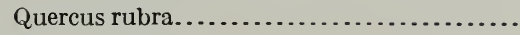 & 39 \\
\hline Juglans nigra................... & 52 & 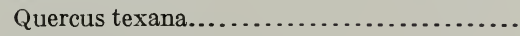 & 40 \\
\hline Larix laricina......... & 67 & Quercus velutina..................... & 39 \\
\hline cidentalis............... & 67 & Robinia pseudacacia..................... & 44 \\
\hline tyraciflua.......... & 55 & (n) & 47 \\
\hline lipifera........... & 57 & ens. . . . & 70 \\
\hline ia acuminata........................ & 58 & hum $\ldots . . . . . . . . . . . .$. & 71 \\
\hline (n. & 58 & talis. . . . . & 71 \\
\hline ( & 44 & 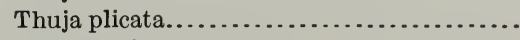 & 71 \\
\hline ( & 57 & (n) & 58 \\
\hline lora $\ldots \ldots \ldots \ldots \ldots \ldots \ldots \ldots \ldots \ldots \ldots$ & 56 & iferum......................... & 43 \\
\hline vatica. . . & 56 & 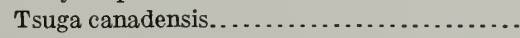 & 69 \\
\hline (n. & 66 & 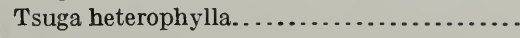 & 70 \\
\hline ( & 65 & 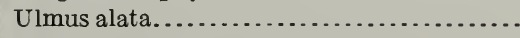 & 42 \\
\hline Picea rubens. . . . . . . . & 66 & 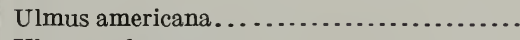 & 41 \\
\hline Pinus aristata. $\ldots \ldots \ldots \ldots \ldots$ & 61 & 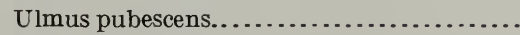 & 42 \\
\hline 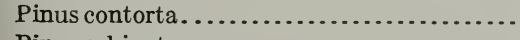 & 62 & Ulmus racemosa............................ & 42 \\
\hline
\end{tabular}




\section{INDEX TO COMMON NAMES.}

[Standard names in C $\Lambda$ PIT $\Lambda$ LS; other names in small type.j

Page. Acacia, three-thorned (HONEY LOCUST) Alligator-wood (RED GUM) ............... Arborvitæ (NORTHER THITE

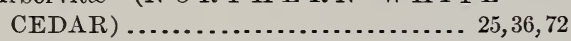
Arborvitæ (WESTERN RED CEDAR)... 71 Arborvitæ, giant (WESTERN RED CEDAR). A SH, American (WHITE ASH) ASH, BLACK................... 21,31,47 Ash, cane (WHITE ASH) . . . . . . . . . . . . 46 ASH, GREEN................... 21, 31,47 ASH, WHITE.................... 21,31, 46 ASPEN, LARGETOOTH............... 55 ASPEN................................ 55 Balm (BLACK COTTONIVOOD)......... 55 Balsam (ALPINE FIR) ................ 69 Balsam (ENGELMANN SPRUCE)....... Balsam (WHITE FIR)................. Balsam, mountain (ALPINE FIR)........ Balsam, white (WHITE FIR)............

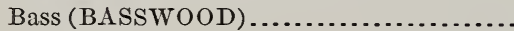
BASSWOOD...................... 23, 33, 58 Bay, sweet (SWEET MAGNOLIA)....... BEECH. ....................... 23, 31,50 Beech, water (SYCAMORE)...

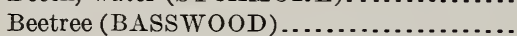
Bigtree (NOBLE FIR).

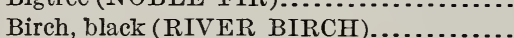
Birch, black (SWEET BIRCH) .......... Birch, canoe (PAPER BIRCH) .......... Birch, cherry (SWEET BIRCH).......... Birch, gray (YELLOW BIRCH).......... BIRCH, PAPER..................... Birch, red (RIVER BIRCH) ............. BIRCH, RIVER ...................... 21, 23, 33,54 Birch, silver (YELLOW BIRCH)......... 53 Birch, swamp (YELLOW BIRCH) ........ 53 BIRCH, SWEET............... 21, 23, 33, 54 Birch, water (RIVER BIRCH).......... 54 Birch, white (PAPER BIRCH).......... 54 BIRCH, YELLOW .............. 21, 23, 33, 53 BITTERNUT (HICKORY)........... 49 Bitternut, water (WATER HICKORY)... 49 BLACK JACK.

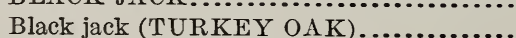
Bois d'Arc (OSAGE ORANGE)........... Buckeye, big (YELLOW BUCKEYE)..... Buckeye, fetid (OHIO BUCKEYE)........ Buckeye, large (YELLOW BUCKEYE)... BUCKEYE, OHIO .............. 23, 33, 59 Buckeye, stinking (OHIO BUCKEYE)... 59 Buckeye, sweet (YELLOW BUCKEYE).. 59 BUCKEYE, YELLOW ............. 23, 33, 59 BUTTERNUT
Buttonball-tree (SYCAMORE)

Page.

Button-wood (SYCAMORE) $\ldots . . .50$

CATALPA, COMMON.................. 45

CATALPA, HARDY............... 21, 29, 45

Catalpa, western (HARDY CATALPA)... 45

Cedar, canoe (WESTERN RED CEDAR).. $\quad 71$

Cedar, gigantic (WESTERN RED CEDAR) 71

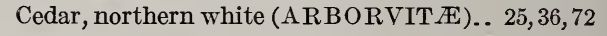

Cedar, Oregon (PORT ORFORD CEDAR). 68

Cedar, Pacific red (WESTERN RED CE-

DAR)............................ 71

CEDAR, PORT ORFORD........... 23, 27, 35,68

Cedar, swamp (WHITE CEDAR)......... 72

CEDAR, WESTERN RED.......... 25,36,71

Cedar, white (ARBORVIT 1 E)............ 72

CEDAR, WHITE..................... 72

Cedar, white (PORT ORFORD CEDAR).. 68

CHERRY, BLACK................ 2?,31,52

Cherry, rum (BLACK CHERRY)......... 52

Cherry, wild (BLACK CHERRY)........ 52 CHESTNUT ....................... 19, 29, 41

Cigartree (HARDY CATALPA)........... 45

Coffee-bean tree (COFFEE TREE)........ 46

Coffee nut (COFFEE TREE)............ 46

COFFEE TREE.................... 19, 29, 46 Coffee tree, Kentucky (COFFEE TREE)... 46

Cotton tree (COTTONWOOD)............ 55 COTTONWOOD................. 21,23,33,55 COTTONWOOD, BLACK.............. 55

COTTONWOOD, SWAMP............. 55

CUCUMBER TREE.................. 59

Cypress (BALD CYPRESS)............. 71

CYPRESS (Western species).............. 71

CYPRESS, B $\Lambda$ LD ................. 25,36,71

Cypress, black (BALD CYPRESS)........ 71 Cypress, Lawson (PORT ORFORD CE$\mathrm{D} \Lambda \mathrm{R})$.

Cypress, red (BALD CYPRESS).......... Cypress, southern (BALD CYPRESS)...... Cypress, swamp (BALD CYPRESS)....... Cypress, white (BALD CYPRESS)......... Cypress, yellow (BALD CYPRESS)........ Date plum (PERSIMMON)............... Elm, American (WHITE ELM) ........... Elm, bastard (HACKBERRY)............ 43 ELM, CORK...................... 21, 29,42 Elm, cork-bark (COR K ELM)............ 42 Elm, corky white (CORK ELM)........... 42 Elm, hickory (CORK ELM).............. 42 Elm, red (SLIPPERY ELM) ............ 42 Elm, rock (CORK ELM)................ 42 Elm, rock (SLIPPERY ELM)............ 42 Elm, rock (WHITE ELM).............. 41 ELM, SLIPPERY ................. 21,29,42 Elm, swamp (WHITE ELM)........... 41 
Page.

Elm, water (WHITE ELM)

ELM, WHITE

ELM, WING.

Fir (DOUGLAS FIR)

FIR, ALPINE . ........ 27,35,69

Fir, balsam (WIIITE FIR) ............ 68

Fir, bracted red (NOBLE FIR).......... 69

FIR, DOUGLAS.................. 25,35,60

Fir, downy-cone (ALPINE FIR).......... 69

Fir, feather-cone red (NOBLE FIR)........ 69

FIR, GRAND................... 27,36,69

Fir, gray (WESTERN HEMLOCK)....... 70

Fir, great California (GR AND FIR)....... 69

Fir, lowland (GRAND FIR)............ 69

FIR, NOBLE .............................. 69

Fir, red (DOU GLAS FIR) ..............

Fir, red (NOBLE FIR)..................

Fir, silver (GRAND FIR) .............. 69

Fir, silver (WHITE FIR)............... $6 \mathrm{~s}$

FIR, WHITE ................... 27,36,68

Fir, white (ALPINE FIR).............. 69

Fir, white (GR AND FIR).............. 69

Fir, yellow (DOUGLAS FIR).............

Fir, yellow (GRAND FIR).

Forked-leaf (TUR KEY OAK).

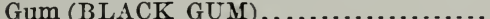

GUM, BLACK..................... 23,33,56

GUM, COTTON................... 23,33,57

GUM, RED..................... 23,33,55

Gum, sour (BLACK GUM).

Gum, sour (COTTON GUM).

56

Gum, star-leaved (RED GUM)........... 55

Gum, sweet (RED GUM)............... 55

Gum, tupelo (BLACK GUM)............. 56

GUM, WATER...................... 56

Gum tree (RED GUM)................. 55

HACKBERRY...................... 19, 29, 43

Hackmatack (TAMARACK)............ 67

Hackmatack (WESTERN LARCH)....... 67

Hack tree (HACKBERRY).............. 43

Hedge plant (OSAGE ORANGE)......... 43

HEMLOCK, EASTERN ............. 27, 36, 69

HEMLOCK, WESTERN............. 27, 36, 70

HICKORIES, PECAN .................. 49

HICKORIES, THE ................ 21, 31,48

HICKORIES, TRUE . . . .............. 49

Hickory, big-bud (MOCKERNUT (HICK-

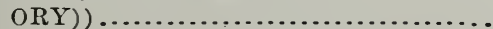

Hickory, bitter (BITTERNUT (HICK-

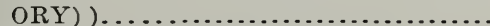

Hickory, black (PIGNUT (HICKORY))...

HICKORY, NUTMEG ..................

Hickory, pig (BITTERNUT (HICKORY))

Hickory, swamp (BITTERNUT (HICK-

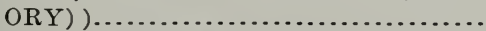

Hickory, swamp (WATER HICKORY)...

Hickory, switch-top (PIGNUT (HICK-

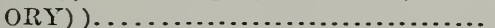

Hickory, tight-bark (PIGNUT (HICK-

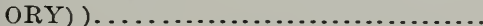

Hickory, upland (SHAGBARK (HICKORY) ).......

Hickory, yellow - twig (SHELLBARK

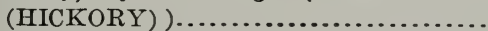

HICKORY, WATER. $21,31,49$
Page.

Hickory, white (MOCKERNUT (HICK-

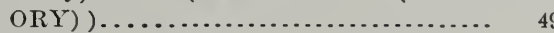

Hickory, whiteheart (MOCKERNUT

(HICKORY) )....................... 49

Hickory, willow (BITTERNUT (HICKORY) )

Hognut (MOCKERNUT (HICKORY)) ...

Honey shucks (HONEY LOCUST) - -....

Horsechestnut, American (OHIO BUCK-

EYE)........................... 59

Indian bean (HARDY CATALPA)....... 45

Juniper (WHITE CEDAR)............

Juniper (TAMARACK)................. 67

Kingnut (SHELLBARK (HICKORY') ).... 49

Larch (NOBLE FIR) .................. 69

Larch (TAMARACK)................. 67

Larch, eastern (TAMARACK) ............ 67

LARCH, WESTERN ............... 25,35,67

Limetree (BASSWOOD)............... $\quad 58$

Linn (BASSWOOD)................... 58

Linden (BASSWOOD).................. 58

Liquidamber (RED GUM)............ $\quad 55$

LOCUST, BLACK................ 19,29,44

Locust, green (BLACK LOCUST). . . . . . 44

LOCUST, HONEY................ 19, 29, 45

Locust, pea-flower (BLACK LOCUST)..... 44

Locust, post (BLACK LOCUST)..........

Locust, thorny (HONEY LOCUST)....... 45

Locust, sweet (HONEY LOCUST)........ $\quad 45$

Locust, yellow (BLACK LOCUST)......... 44

Magnolia, mountain (CUCUMBER-TREE). $\quad 58$

MAGNOLIA, SWEET ................ 58

Maple, black (SUGAR MAPLE).......... 51

Maple, hard (SUGAR MAPLE) ..........

MAPLE, RED .................. 23, 31, 33, 52

Maple, river (SILVER MAPLE)..........

Maple, rock (SUGAR MAPLE)........... 51

MAPLE, SILVER................ 23, 31, 33, 51

Maple, soft (SILVER MAPLE).......... 51

MAPLE, SUGAR .................. 23, 31,51

Maple, swamp (SILVER MAPLE)...... . 51

Maple, water (SILVER MAPLE).......... 51

Maple, white (SILVER MAPLE)......... 51

MOCKERNUT (HICKORY)........... $\quad 49$

Mulberry, black (RED MULBERRY)..... 44

MULBERRY, RED................ 19, 29,44

Nettle-tree (HACKBERRY).............. 43

Oak, barren (BLACK JACK)............ $\quad 40$

Oak, barren scrub (TURKEY OAK)...... 40

Oak, basket (COW OA K)...............

Oak, black (YELLOW OAK........... $\quad 39$

Oak, black (BLACK JACK)............. 40

Oak, black (RED OAK)............... $\quad 39$

Oak, black (SCARLET OAK)............ 40

Oak, blue (BUR OAK)................ $\quad 38$

Oak, box white (POST OAK)............ 38

49 OAK, BUR........................... 38

OAK, CHESTNUT.................... 38

Oak, chestnut (CHINQUAPIN OAK)..... $\quad 38$

OAK, CHINQUAPIN................. $\quad 38$

OAK, COW............................. 38

Oak, Darlington (LAUREL OAK)........

Oak, duck (WATER OAK)............. 40

Oak, dwarf chestnut (CHINQUAPIN OAK) 38

Oak, dyer's (YELLOW OAK).......... 39

Oak, iron (BLACK JACK)............ 
Page.

Oak, jack (BLACK JACK) ................ Oak, jack (SHINGLE OAK) . ............ OAK, LAUREL ........................ Oak, laurel (SHINGLE OAK)............ Oak, mossy cup (BUR OAK).............. Oak, mossy cup white (BUR OAK)......... OAK, OVERCUP.

Oak, overcup (BUR OAK) ................ Oak, overcup white (BUR OAK)........... Oak, peach (WILLOW OAK)............. OAK, PIN.

Oak, possum (WATER OAK).

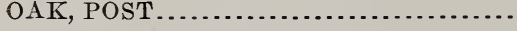
Oak, punk (WATER OAK).............. Oak, quercitron (YELLOW OAK) .........

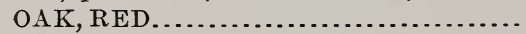
OAK, RED (OAK) GROUP.

Oak, red (SCARLET OAK).............. Oak, red (SPANISH OAK)................ Oak, red (TEXAN OAK)................. Oak, rock (CHESTNUT OAK) ............ Oak, rock (CHINQUAPIN OAK).......... Oak, rock chestnut (CHESTNUT OAK).... OAK, SCARLET.

Oak, scrub (BLACK JACK) .............. Oak, scrub (BUR OAK) ................... Oak, scrub (CHINQUAPIN OAK)......... Oak, scrub (TUR KEY OAK).............. OAK, SHINGLE.

Oak, shrub (CHINQUAPIN OAK)........ OAK, SPANISH...................... Oak, Spanish (RED OAK)................ Oak, Spanish (SCARLET OAK)........... Oak, Spanish (TEXAN OAK)............. Oak, Spanish water (SPANISH OAK)...... Oak, spotted (YELLOW OAK)............ Oak, spotted (TEXAN OAK).............. Oak, spotted (WATER OAK)............. Oak, stave (WHITE OAK)...

Oak, swamp (SWAMP WHITE OAK)..... Oak, swamp chestnut (COW OAK)......... Oak, swamp laurel (LAUREL OAK)....... Oak, swamp post (OVERCUP OAK)....... Oak, swamp Spanish (PIN OAK)........... OAK, SWAMP WHITE.................. Oak, swamp white (COW OAK)............ Oak, swamp white (OVERCUP OAK)..... Oak, tanbark (YELLOW OAK)............ Oak, tanbark (CHESTNUT OAK)......... OAK, TEXAN.......................... OAK, TURKEY.

OAK, WATER......................... Oak, water (LAUREL OAK)............. Oak, water (PIN OAK)................... Oak, water (SHINGLE OAK)............. Oak, water (WILLOW OAK) ............. Oak, water Spanish (PIN OAK)........... Oak, water white (OVERCUP OAK)....... OAK, WHITE.

Oak, white (CHINQUAPIN OAK) ......... OAK, WHITE (OAK) GROUP........ 19, Oak, white (POST OAK)................. OAK, WILLOW ........................ Oak, willow (LAUREL OAK)............ OAK, YELLOW.
Page.

Oak, yellow (CHINQUAPIN OAK)....... 38

Oak, yellow-barked (YELLOW OAK)...... 39

OAKS, THE...................... 19,27,37

Orange, mock (OSAGE ORANGE)......... 43

Olivetree, wild (COTTON GUM) .......... 57

OSAGE ORANGE.................. 19,29, 43

PECAN (HICKORY)................... 49

Pecan, bitter (WATER HICKORY)........ 49

Pepperidge (BLACK GUM).............. 56

PERSIMMON...................... 21,31, 48

Pignut (BITTERNUT (HICKORY) ) ..... 49

PIGNUT (HICKORY).................. 49

Pine, Alaska (WESTERN HEMLOCK).... 70

Pine, bastard (SLASH PINE)............ 65

Pine, bastard (LOBLOLLY PINE)........ 64

Pine, bastard (POND PINE) .............. 65

Pine, big (WESTERN YELLOW PINE).. 62

Pine, bird's-eye (LODGEPOLE PINE).... 62

Pine, black (PITCH PINE)............... 64

Pine, black Norway (PITCH PINE)........ 64

YINE, BRISTLE-CONE.............. 25, 35, 61

Pine, bull (LOBLOLLY PINE).......... 64

PINE, BRISTLE-CONE.............. 25, 35, 61

Pine, bull (LOBLOLLY PINE) ........... 64

Pine, bull (POND PINE)................ 65

Pine, bull (SHORTLEAF PINE)........ 61

Pine, bull (WESTERN YELLOW PINE) . 62

Pine, Cuban (SLASH PINE)............. 65

Pine, fat (LONGLEAF PINE)........... 65

Pine, finger-cone (WESTERN WHITE

PINE)............................ 60

Pine, Georgia (LONGLEAF PINE)....... 65

Pine, ginger (PORT ORFORD CEDAR)... $\quad 68$

Pine, hard (LONGLEAF PINE) .......... 65

Pine, hard (PITCH PINE) . .............. 64

Pine, heart (LONGLEAF PINE) .......... 65

Pine, Idaho white (WESTERN WAITE

PINE) ................................. 60 PINE, LIMBER ..................... 23, 35, 61 PINE, LOBLOLLY............... 25, 35, 64 Pine, loblolly (POND PINE)............ 65 PINE, LODGEPOLE ............ 25, 27, 35, 62 PINE, LONGLEAF ................. 25, 35, 65 Pine, longstraw (LONGLEAF PINE)..... 65 Pine, marsh (POND PINE) .............. 65 Pine, meadow (POND PINE)............ 65 Pine, mountain (WESTERN WHITE PINE) ............................... Pine, North Carolina yellow (SHORTLEAF

PINE) .............................. PINE, NORWAY................... 25, 35,63 Pine, nut (PIÑON (PINE)) .............. 61 Pine, oldfield (LOBLOLLY PINE)......... 64 Pine, oldfield (SHORTLEAF PINE)...... 64 Pine, Oregon (DOUGLAS FIR).......... 66 PINE, PITCH................... 25,35, 64 Pine, pitch (LONGLEAF PINE)......... 65 Pine, pitch (WESTERN YELLOW PINE) 62 PINE, POND ..................... 25, 35, 65 Pine, Puget Sound (DOUGLAS FIR)...... 66 Pine, red (DOUGLAS FIR).............. 66 Pine, red (NOR WAY PINE)............. 63 Pine, red (WESTERN YELLOW PINE). 62 Pine, Rocky Mountain white (LIMBER

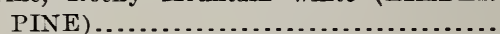
Pine, rosemary (LOBLOLI.Y PINE)...... 64 
Page.

Pine, rosemary (LONGLEAF PINE)...... 65 Pine, rosemary (SHORTLE AF PINE)..... $\quad 64$ Pine, sand (LODGEPOLE PINE)........ 62

Pine, sap (LOBLOLLY PINE) ........... 64

Pine, scrub (LODGE POLE PINE)....... 62

PINE, SHORTLEAF.............. 25, 35, 64

Pine, shortleaf (LOBLOLLY PINE)...... 64 Pine, silver (WESTERN WHITE PINE). 60 PINE, SLASH.................... 25, 35,65

Pine, slash (LOBLOLLY PINE)

Pine, slash (SHORTLEAF PINE)......... Pine, soft (WESTERN WHITE PINE)... Pine, southern pitch (LONGLEAF PINE) Pine, southern yellow (LONGLEAF PINE) Pine, spruce (EASTERN HEMLOCK)..... Pine, spruce (POND PINE).............. Pine, spruce (SHORTLEAF PINE)........

Pine, swamp (SLASH PINE)............. Pine, swamp (LOBLOLLY PINE)......... Pine, torch (LOBLOLLY PINE)......... Pine, turpentine (LONGLEAF PINE)..... Pine, western (WESTERN YELLOW PINE). PINE, TVESTERN TWHTTE PINE, WESTERN YELLOW........ 25,35,62

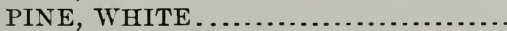
Pine, white (LIMBER PINE)............ Pine, white (WESTERN WHITE PINE). Pine, white (WESTERN YELLOW PINE) Pine, yellow (LONGLEAF PINE) ......... Pine, yellow (PITCH PINE).............. Pine, yellow (SHORTLEAF PINE)...... PINES, THE. $23,35,5$ PIÑON (PINE) . Piñon, New Mexican (PIÑON (PINE)).... Plane-tree (SYCAMORE).

Poplar (COTTONWOOD)

Poplar, bay (COTTON GUM)

Poplar, blue (YELLOW POPLAR)........ Poplar, hickory (YELLOW POPLAR).... Poplar, tulip (YELLOW POPLAR)...... Poplar, white (YELLOW POPLAR)...... POPLAR, YELLOW................ 23, 33, 57 Possumwood (PERSIMMON)............ 43 REDWOOD..................... 25, 26,70
Page. SASSAFRAS .................... 19,31,47 Saxifrax (SASSAFRAS)............... 47 Scalybark (SHAGBARK (HICKORY)).... 49 Sequoia (REDWOOD)................. $\quad 70$ SHAGBARK (HICKORY)............. 49 Shellbark (SHAGBARK (HICKORY)).... 49 SHELLBAR K (HICKORY).............. 49 Shellbark (SHELLBARK (HICKORY))... 49 Shellbark, big-fruited (SHELLBARK (HICKORY))...................... 49 Shellbark, bottom (SHELLBARK (HICKORY))........................ 49 Shellbark, thick (SHELLBARK (HICK-

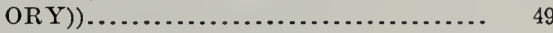
Shellbark, western (SHELLBARK (HICK-

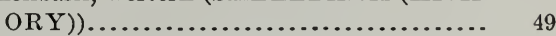
Shinglewood (WESTERN RED CEDAR). 71 Spruce (DOUGLAS FIR).............. 66 Spruce, Douglas (DOUGLAS FIR)....... 66 SPRUCE, ENGELMANN ........... 27, 35, 65 Spruce, hemlock (EASTERN HEMLOCK). 69 Spruce, mountain (ENGELMANN SPRUCE)........................... 65 SPRUCE, RED ....................... 66 SPRUCE, WHITE.................... 66 Spruce, white (ENGELMANN SPRUCE).. 65 SUGA KBERRY ................... 19, 29, 43 Sugarberry (HACKBERRY) ............ 43 Sugar-tree (SUGAR MAPLE)............ 51 SYCAMORE..................... 23,31,50 TAMARACK.................... 25,35,67 Tamarack (LODGEPOLE PINE)........ 62 Tamarack (WESTERN LARCH)........ 67 Tupelo (COTTON GUM) ............ 23, 33,57 Tupelo (BLACK GUM)............... $\quad 56$ Tupelo, large (COTTON GUM)........... 57 Tupelo, swamp (COTTON GUM)......... 57 Walnut (BUTTERNUT) ............... 53 WALNUT, BLACK................ 21,33, 52 Walnut, white (BUTTERNUT).......... 53 Waternut, bitter (NUTMEG HICKORY).. 49 Whitewood (BASSWOOD)................ 59 Whitewood (COTTONWOOD)........... 55 Whitewood (YELLOW POPLAR)......... 57 Yellowwood (OSAGE ORANGE)........ 43 
Forest Service, U. S. Dept. of Agriculture. Identification of Woods.

Plate II.

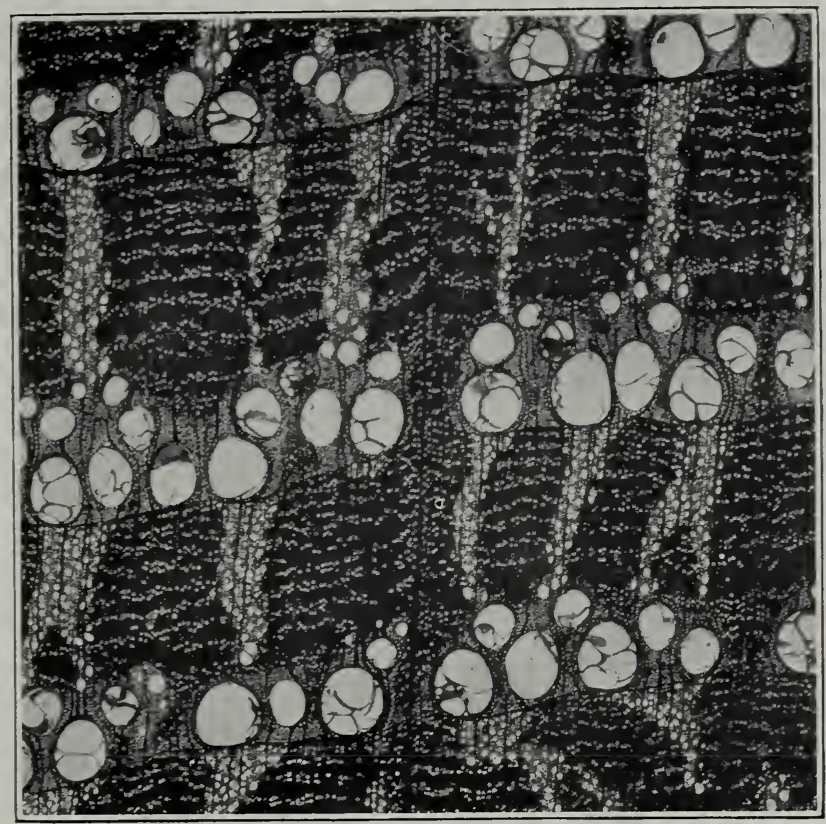

FIG. 1.-WHITE OAK.

Cross section magnıfied $1 J$ diameters.

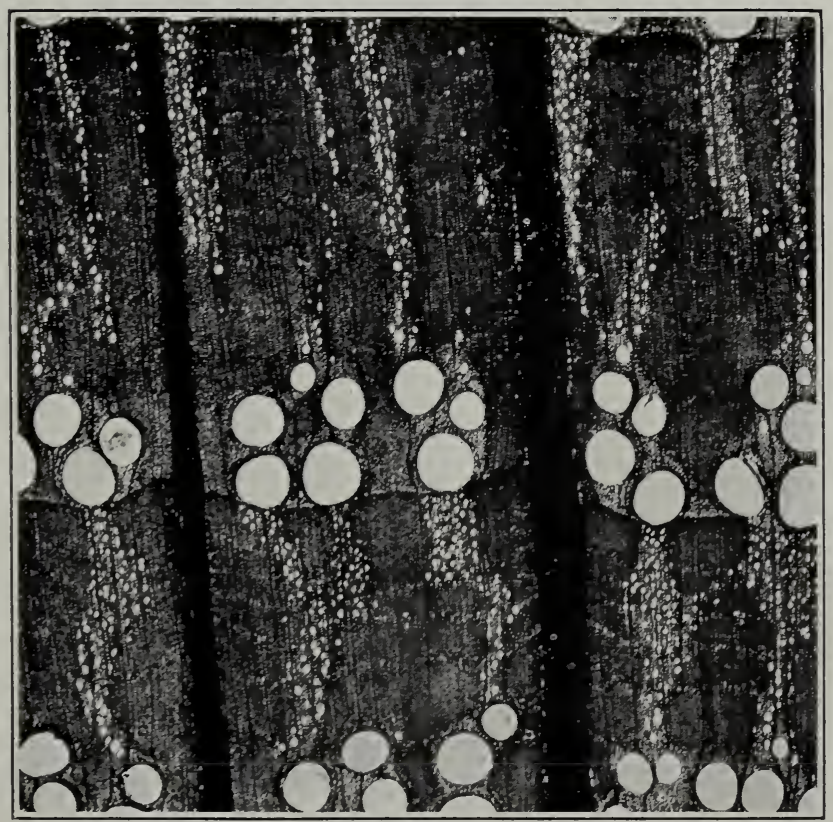

FIG. 2.-CHESTNUT OAK.

Cross section magnitied 15 diameters. 


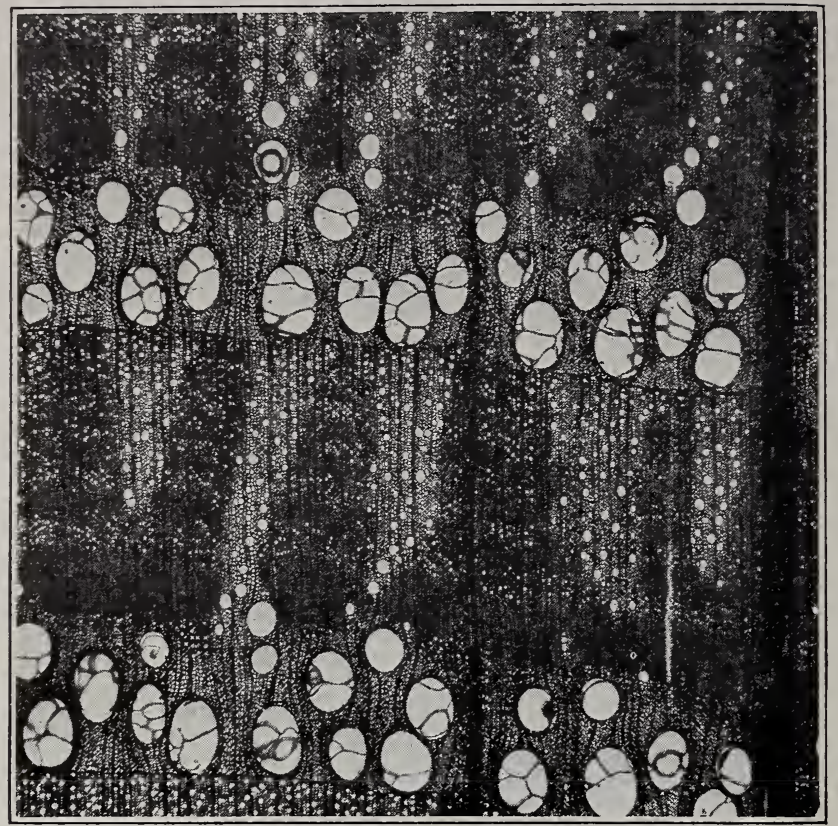

FIG. 1.-POST OAK.

Cross section magnified 15 diameters.

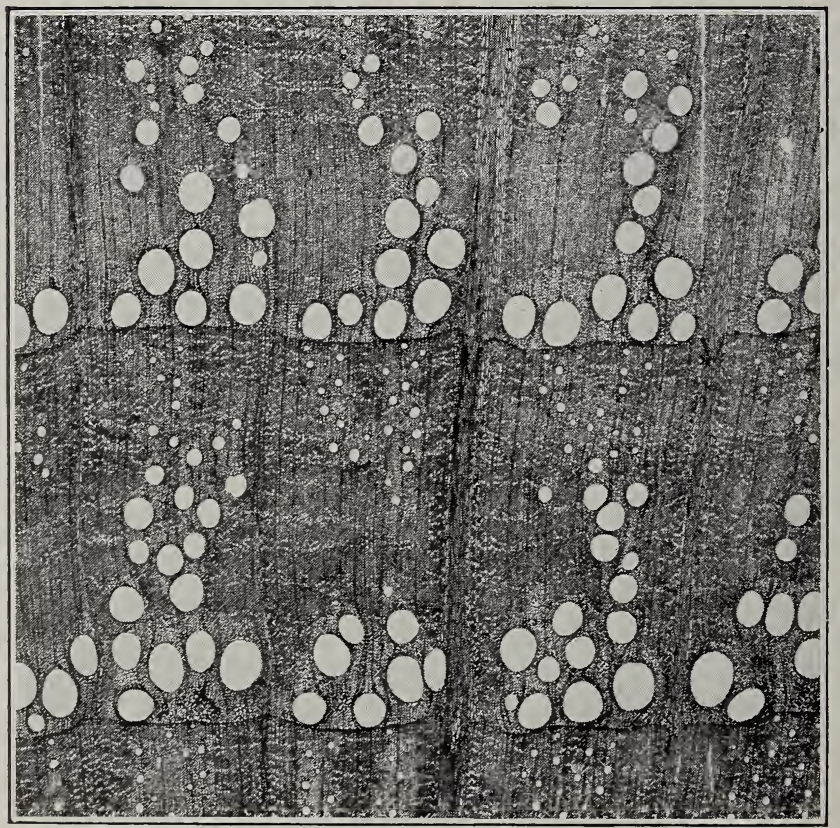

FIG. 2.-RED OAK.

Cross section magnified 15 diameter's. 


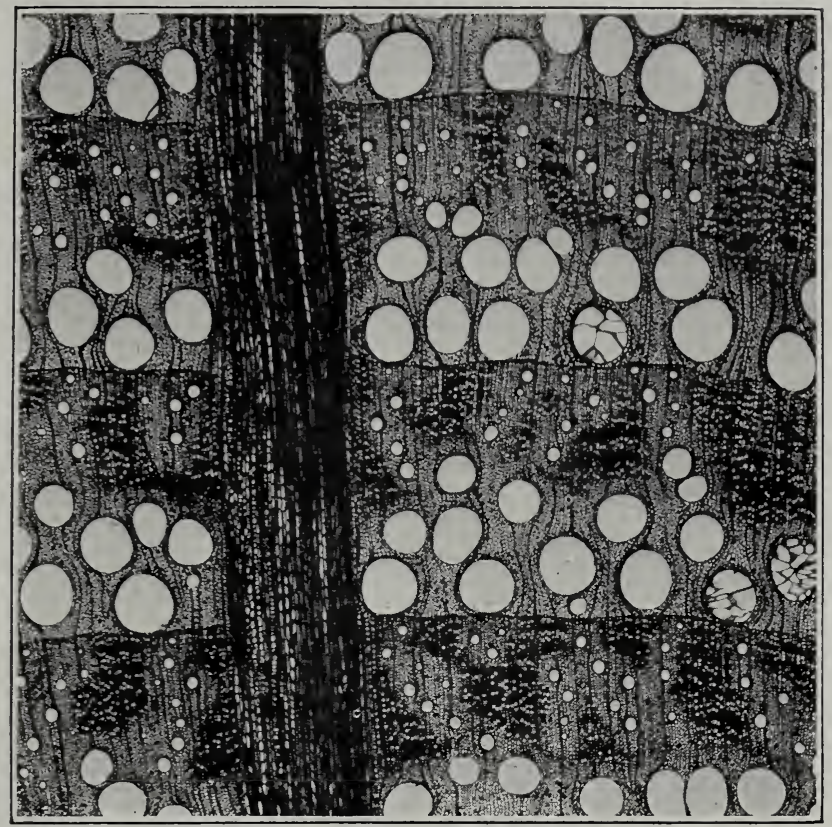

FIG. 1.-YELLOW OAK.

Cross section magnified 15 diameters.

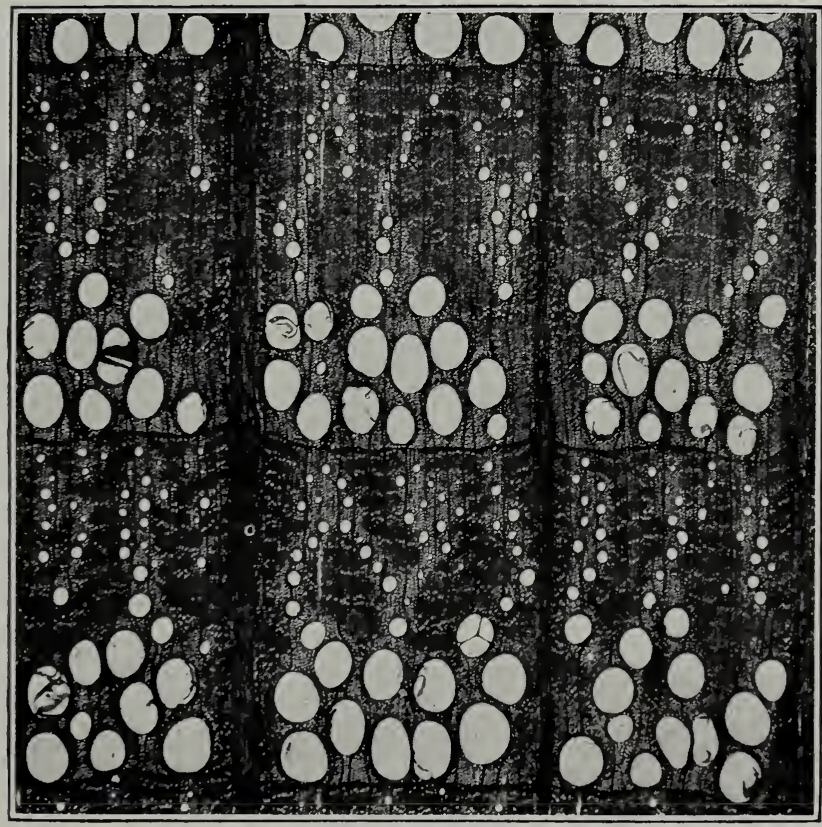

FIG. 2.-PIN OAK.

Cross section magnified 15 diameters. 


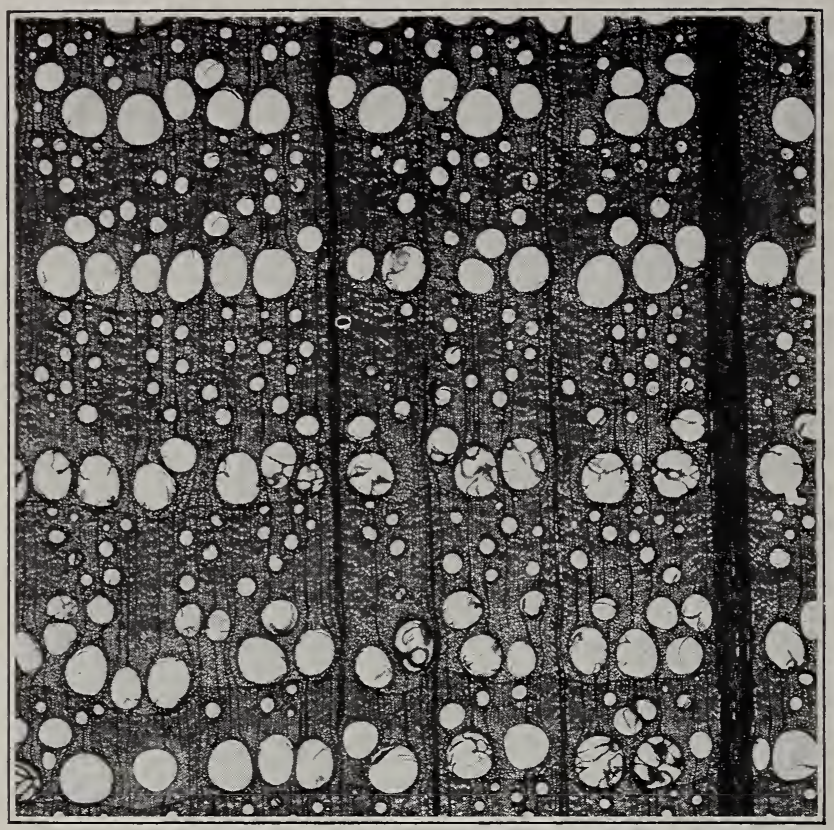

FIG. 1.-WILLOW OAK.

Cross section magnified 15 diameters.

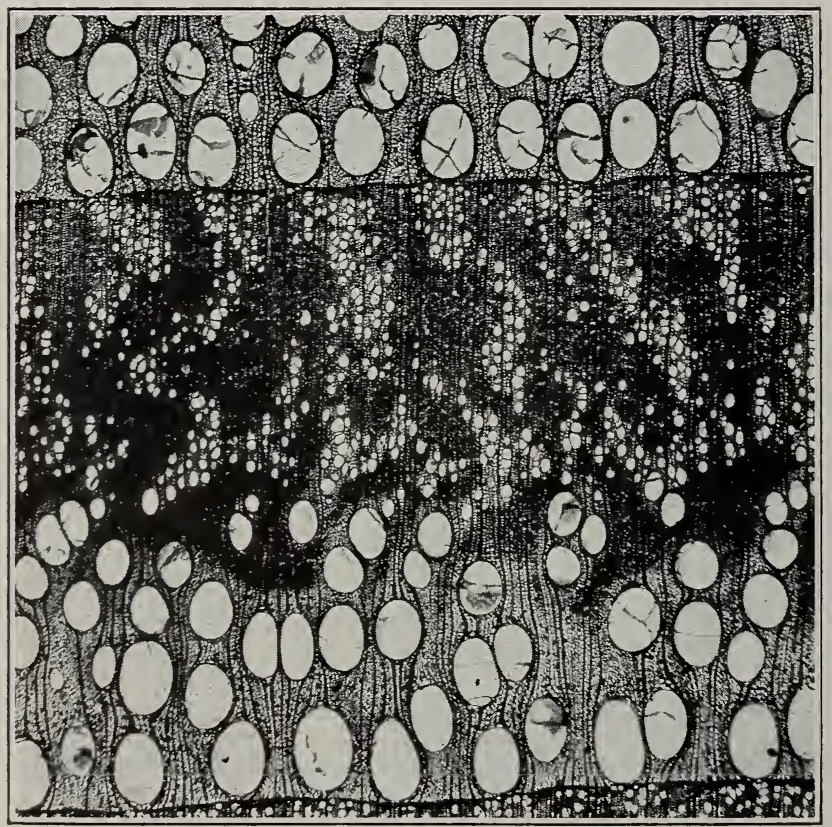

FIG. 2.-CHESTNUT.

Cross section magnified 15 diameters. 


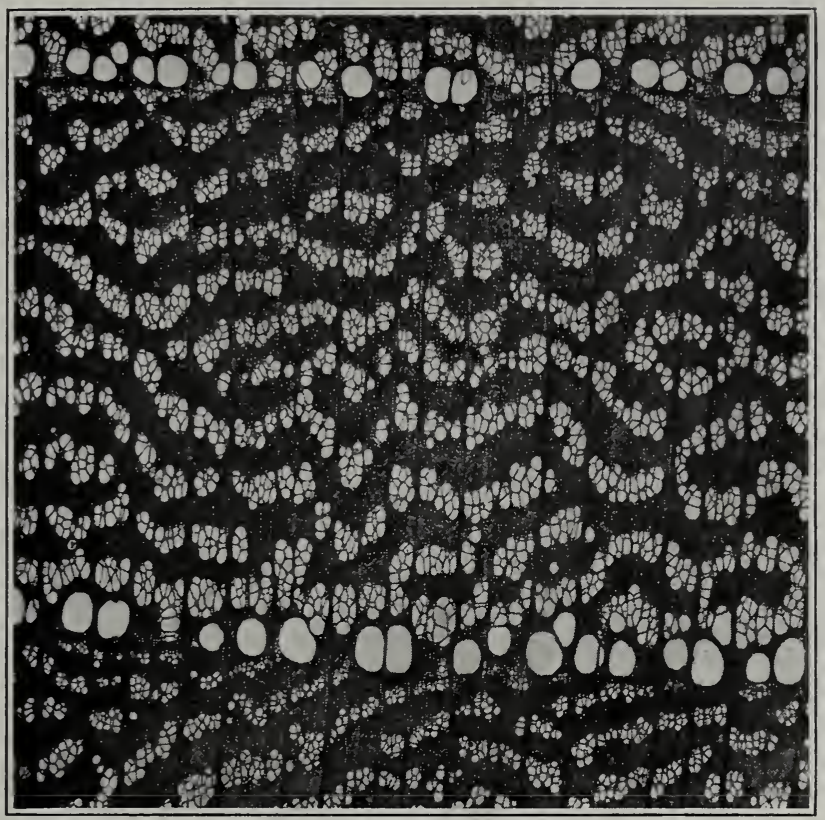

FIG. 1,-WHITE ELM.

Cross section magnified 15 diameters.

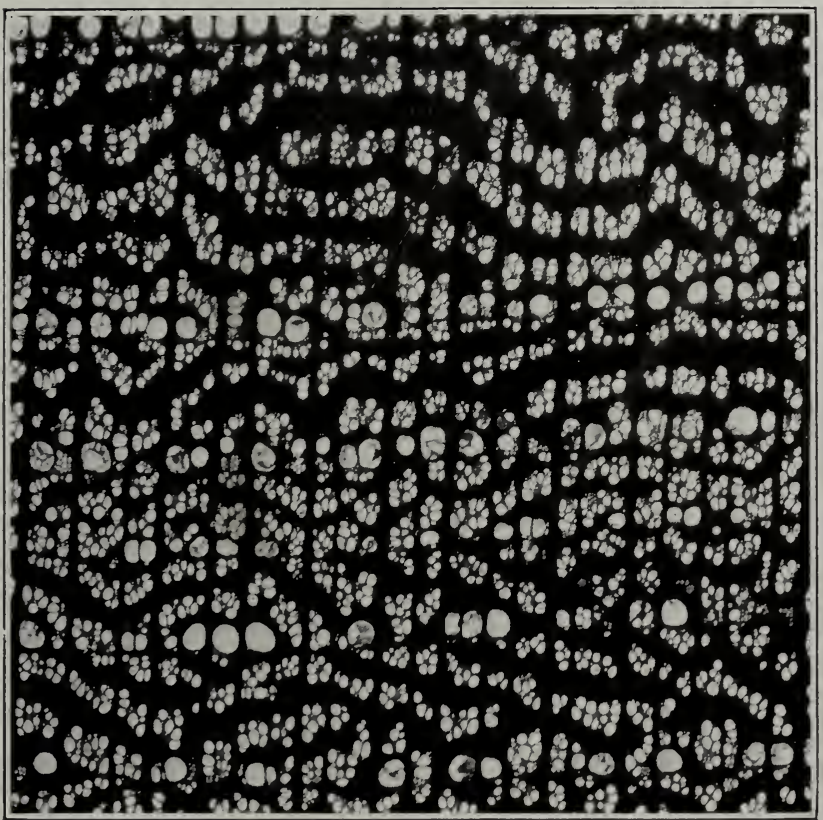

FIG. 2.-CORK ELM.

Cross section magnified 15 diameters. 


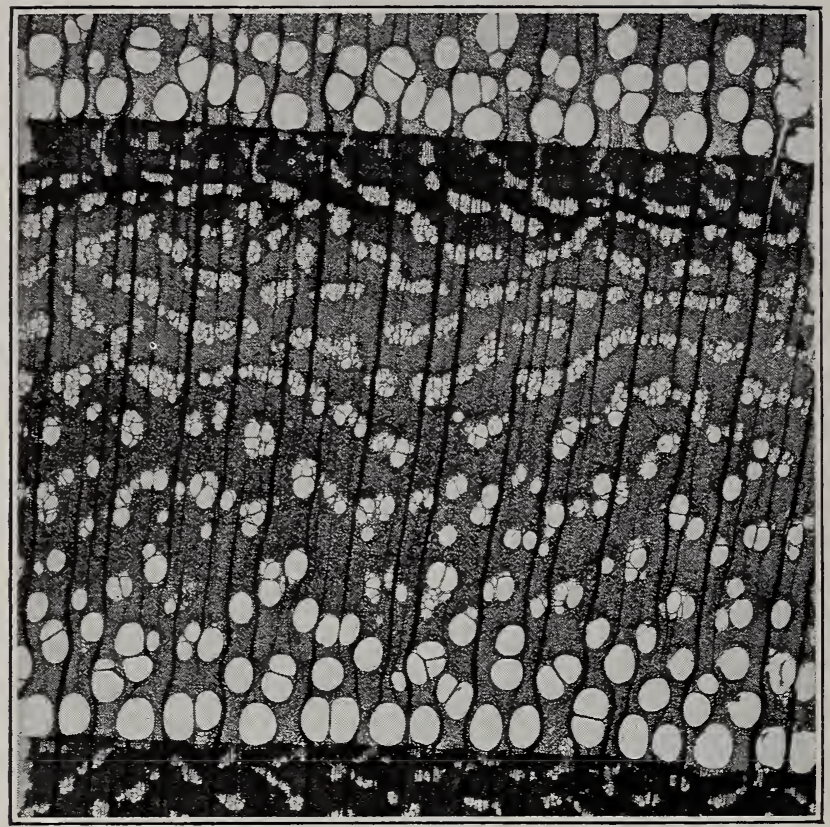

FIG. 1.-SLIPPERY ELM.

Cross section magnified 15 diameters.

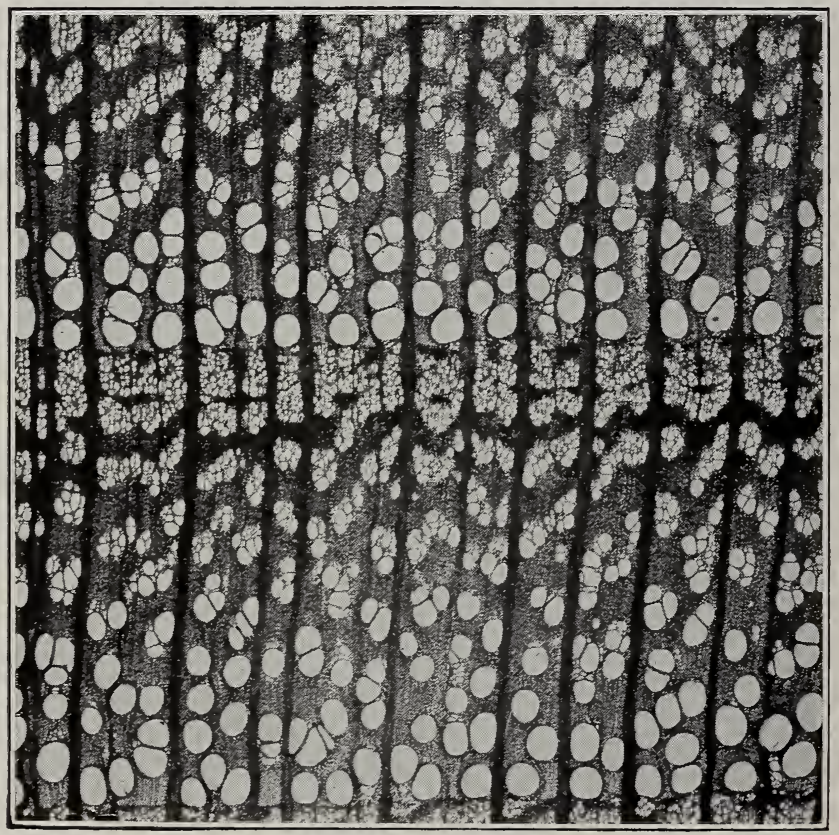

FIG. 2.- HACKBERRY.

Cross section magnified 15 diameters. 


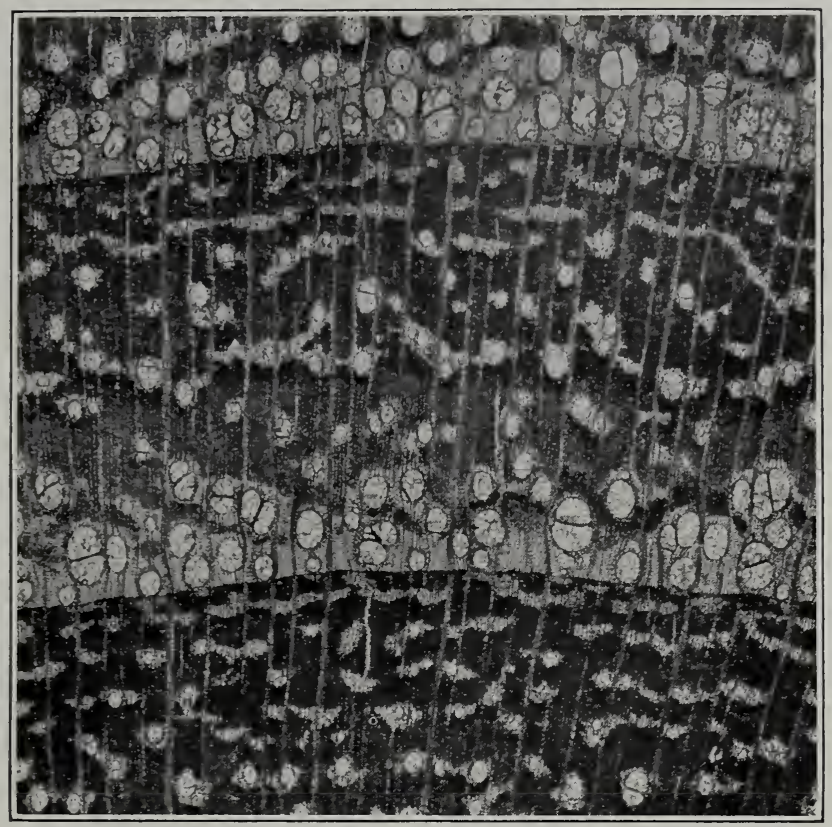

Fig. 1.-Osage Orange.

Cross section magnified 15 diameters.

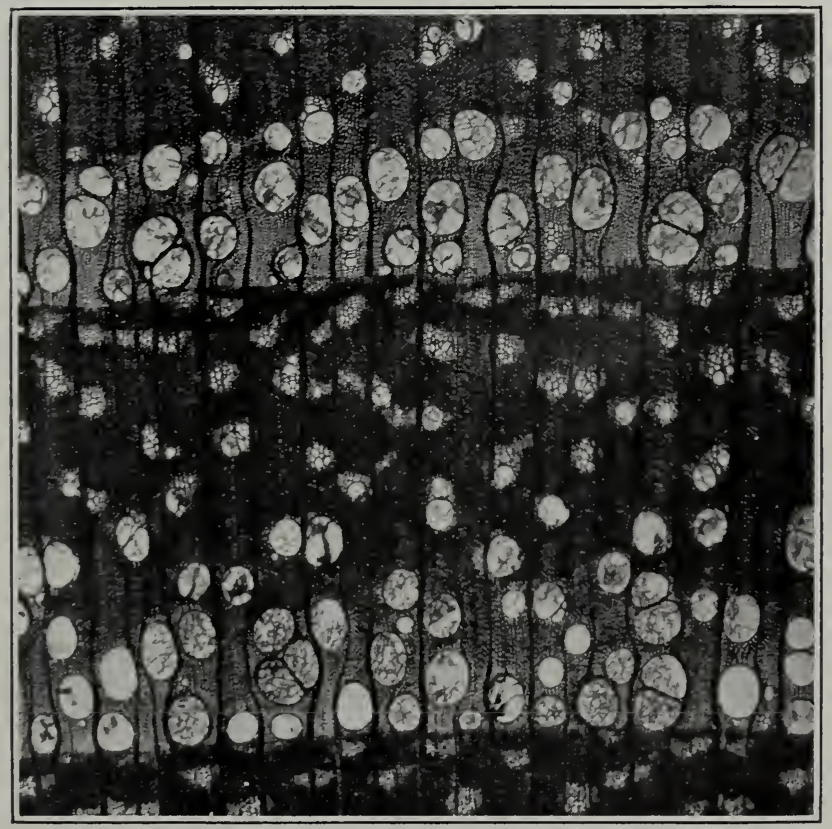

FIG. 2.-BLACK LOCUST.

Cross section magnified 15 diameters. 


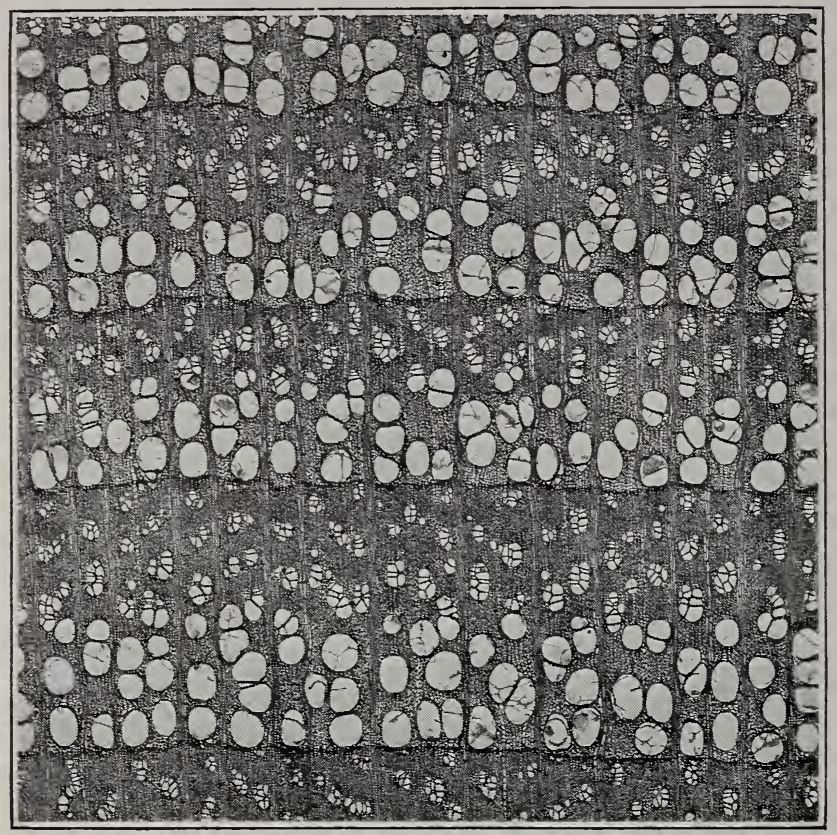

FIG. 1.-RED MULBERRY.

Cross section magnified 15 diameters.

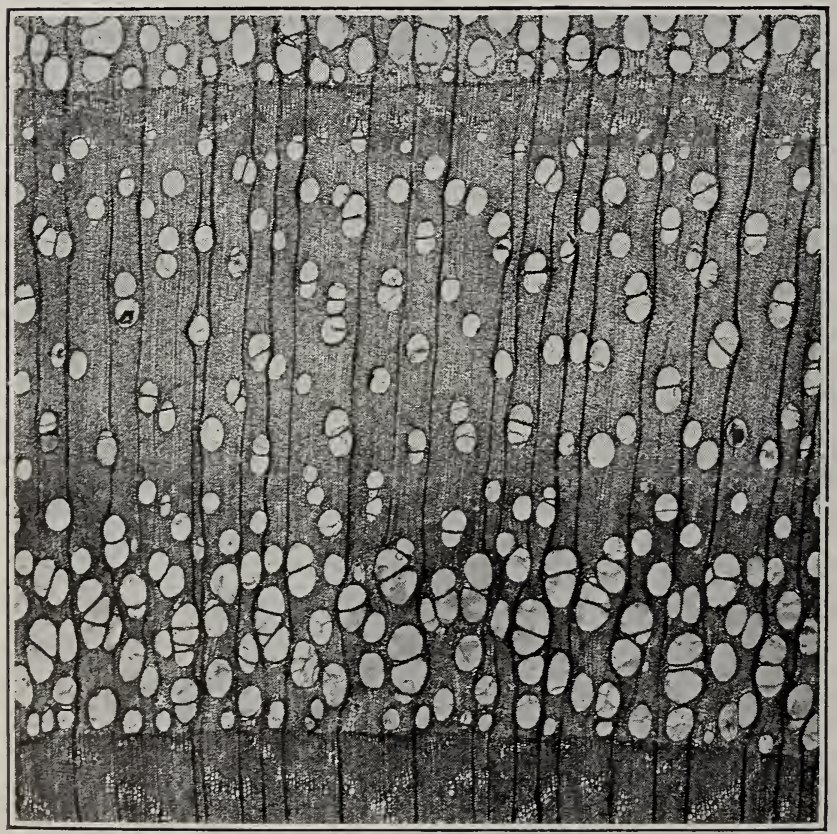

FIG. 2.-HARDY CATALPA.

Cross section magnified 15 diameters. 


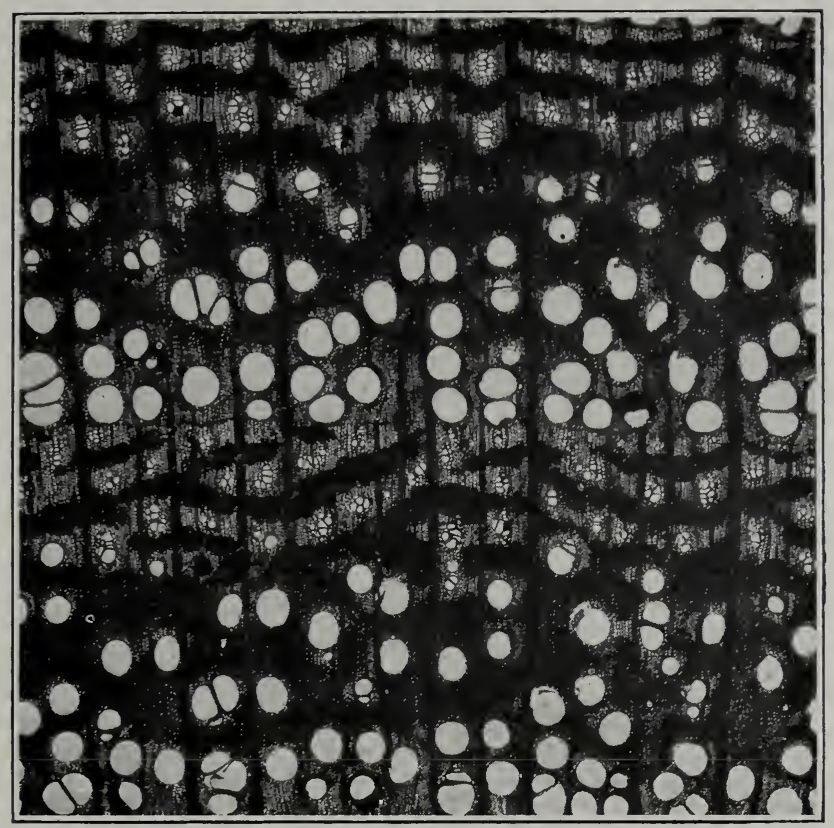

Fig. 1.-HONEY LOCUST.

Cross section maguified 15 diameters.

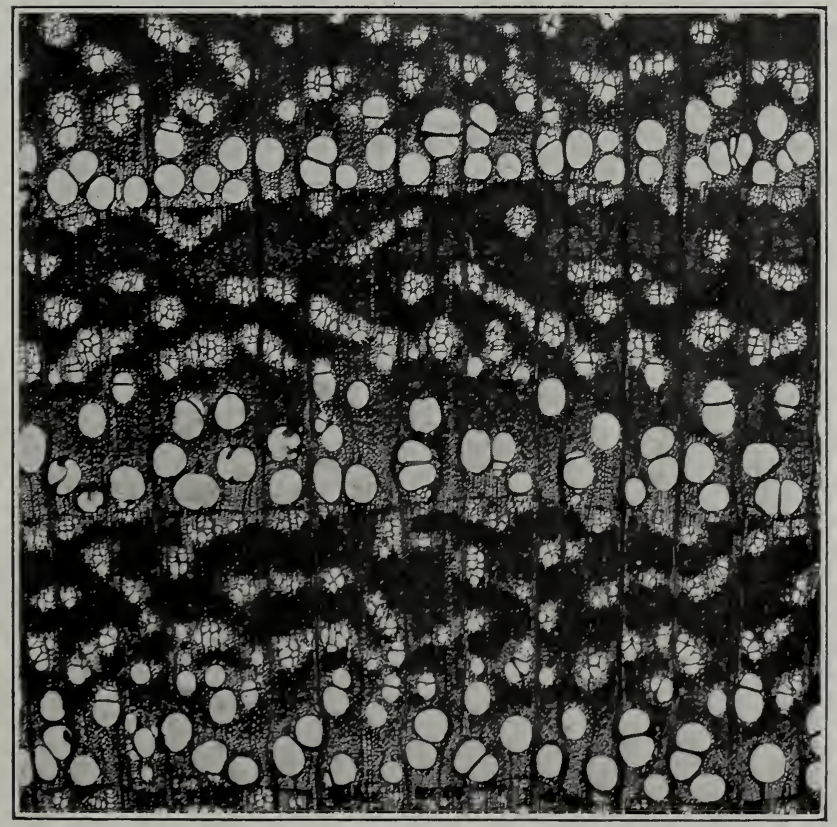

Fig. 2.-Coffeetree.

Cross section magnified 15 diameters. 


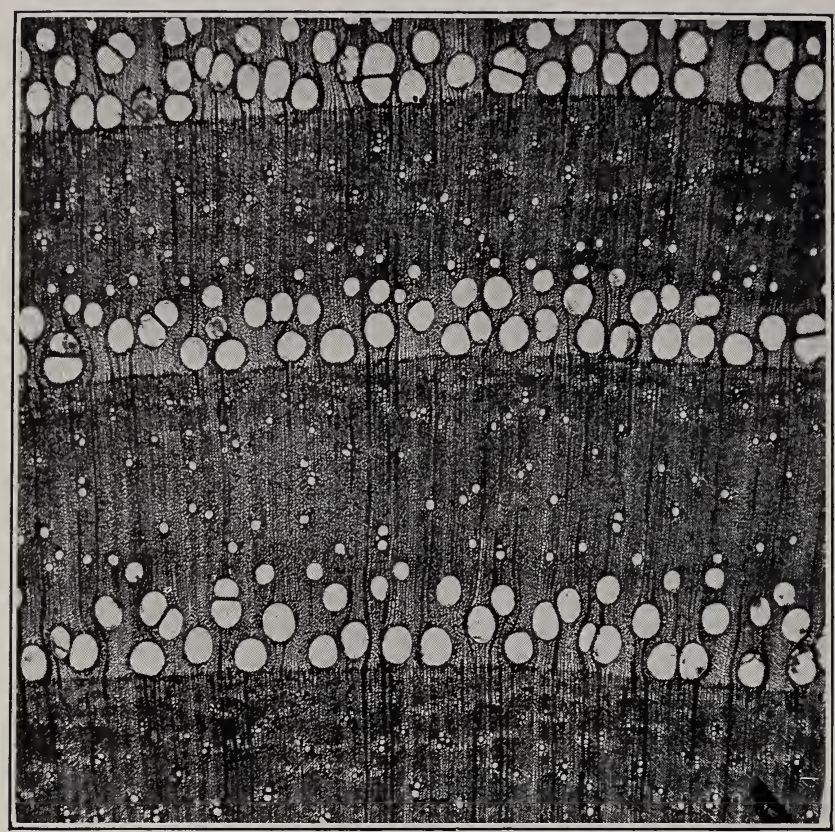

FIG. 1.-WHITE ASH.

Cross section magnified 15 diameters.

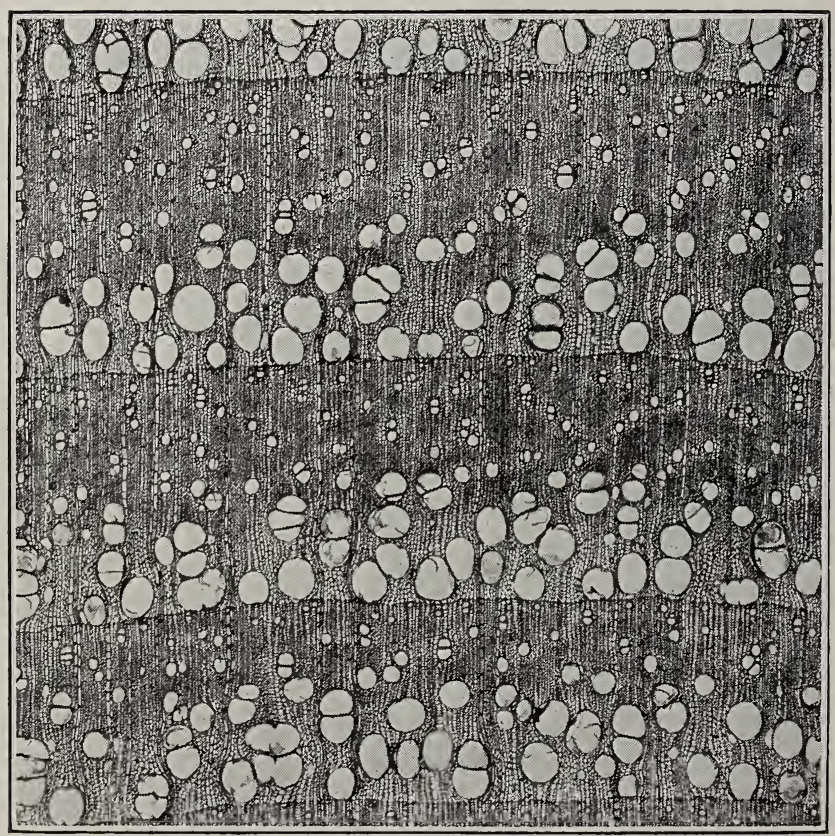

FIG. 2.-SASSAFRAS.

Cross section magnified 15 diameters. 


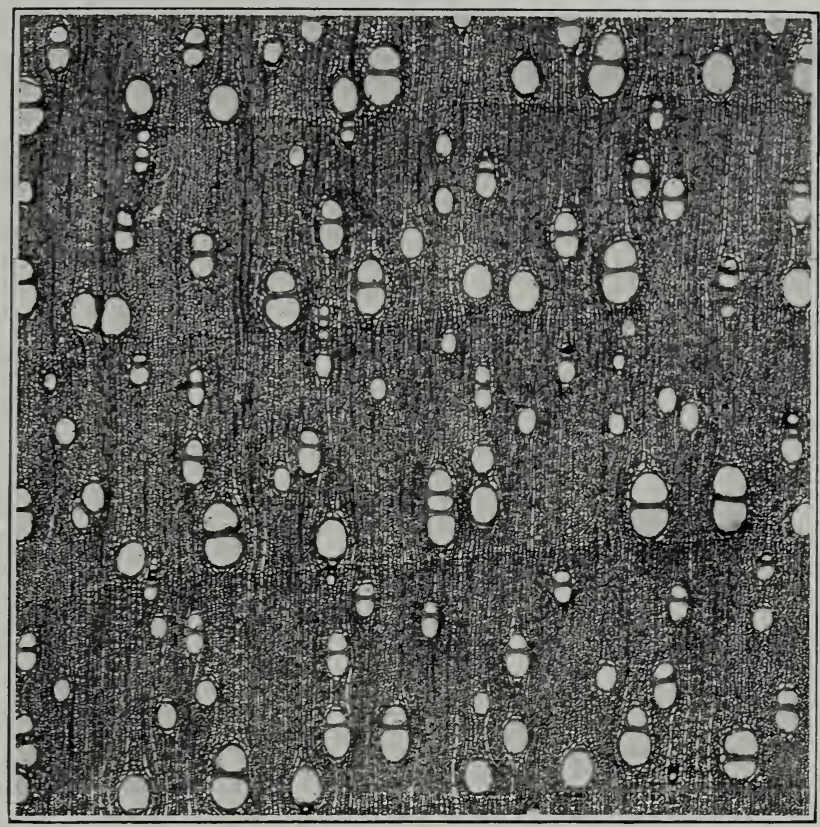

Fig. 1.-PERSIMMON.

Cross section magnified 15 diameters.

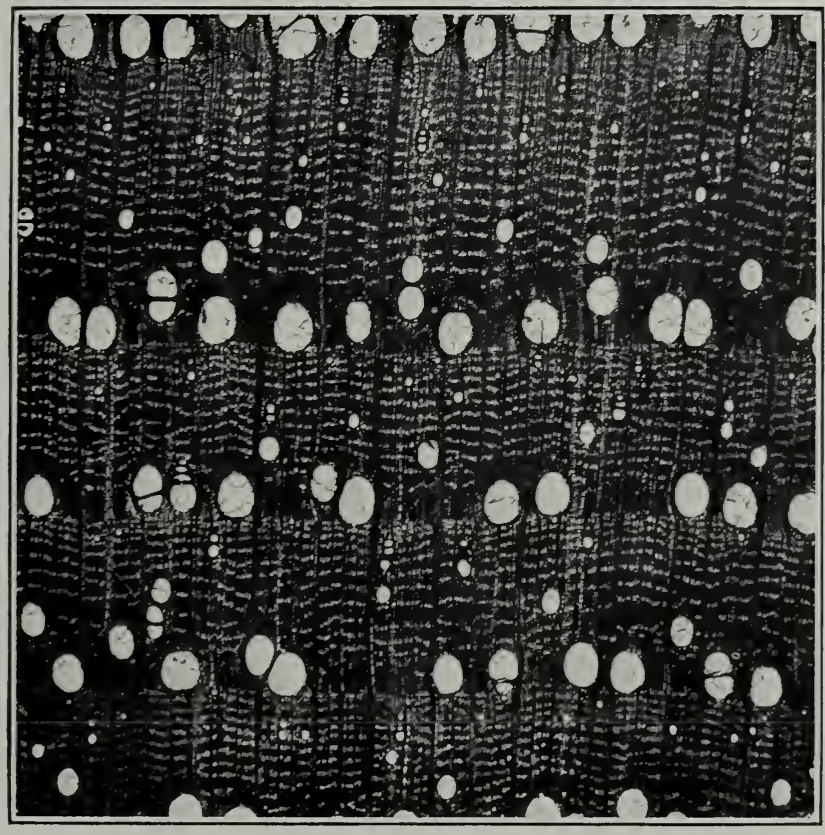

FIG. 2.-SHAGBARK (HICKORY).

Cross section magnified 15 diameters. 


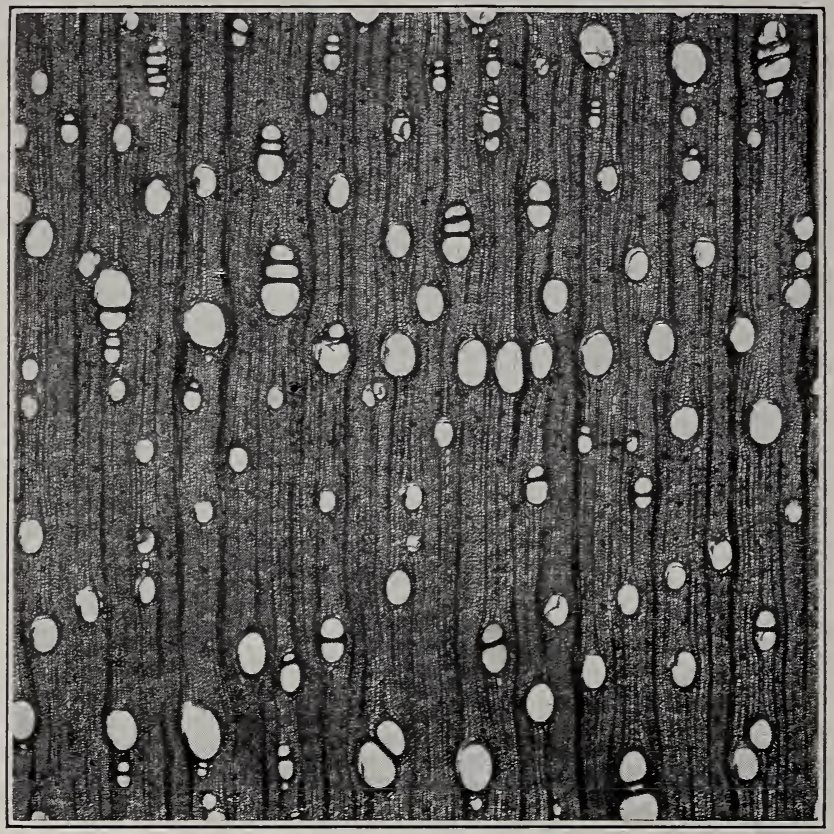

FIQ. 1.-WATER HICKORY.

Cross section magnified 15 diameters.

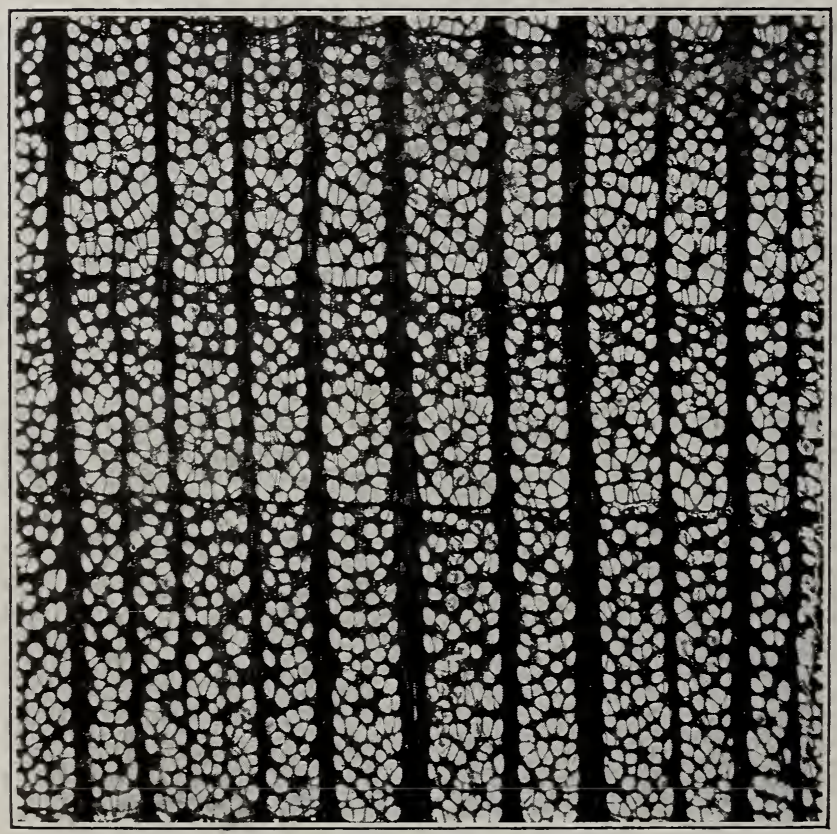

FIG. 2.-SYCAMORE.

Cross section magnified 1.5 diameters. 


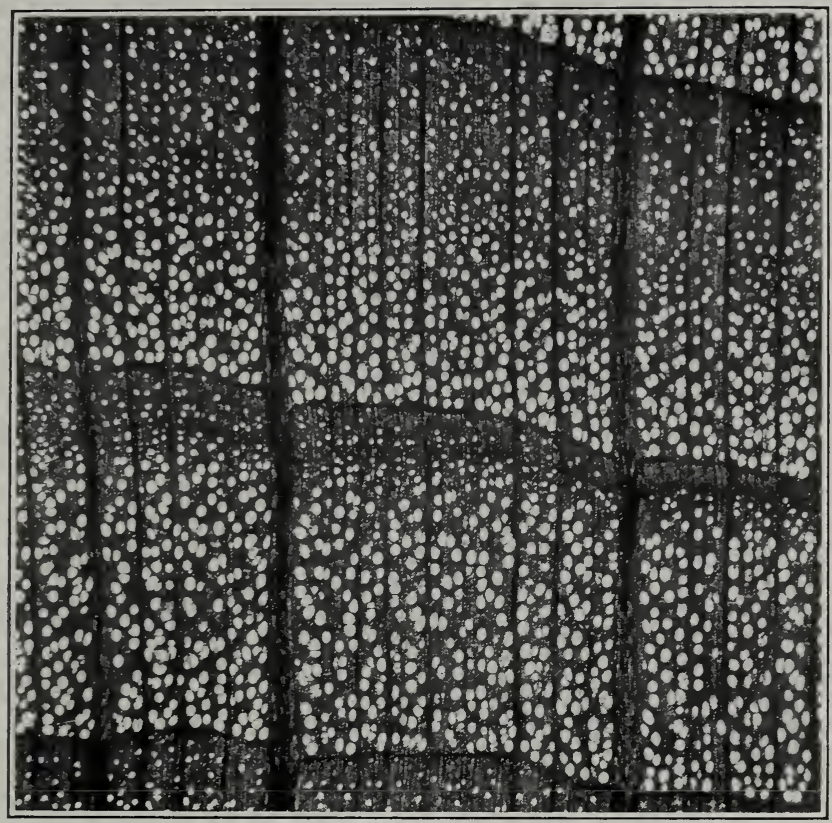

FIG. 1. - BEECH.

Cross section magnified 15 diameters.

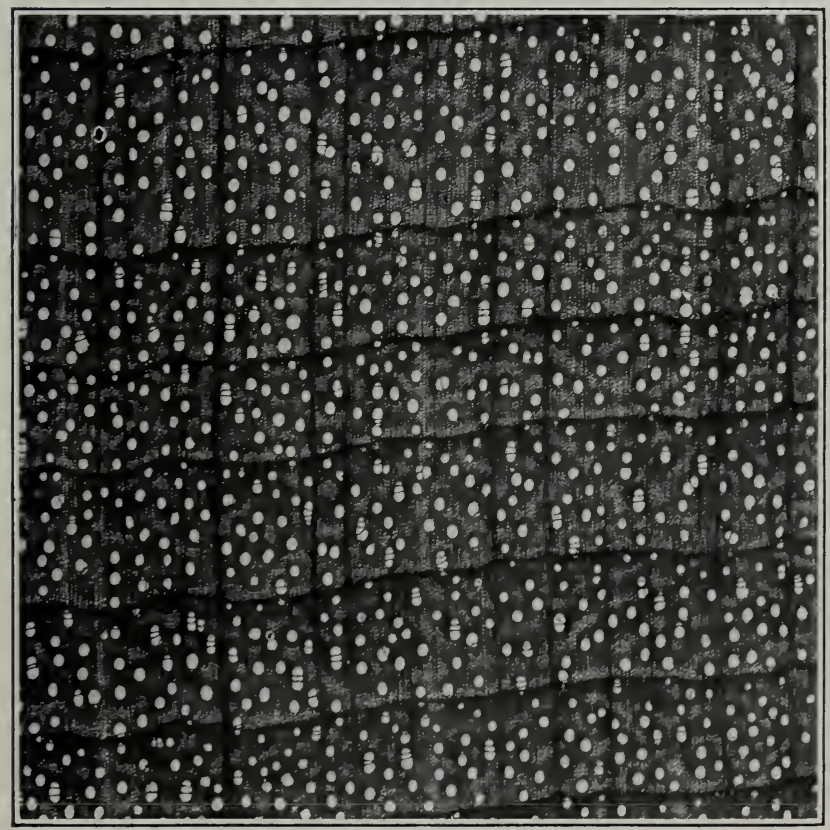

FIQ. 2.-SUGAR MAPLE.

Cross section magnified 15 diameters. 
Forest Service, U. S. Dept. of Agriculture. Identification of Woods.

Plate XV。

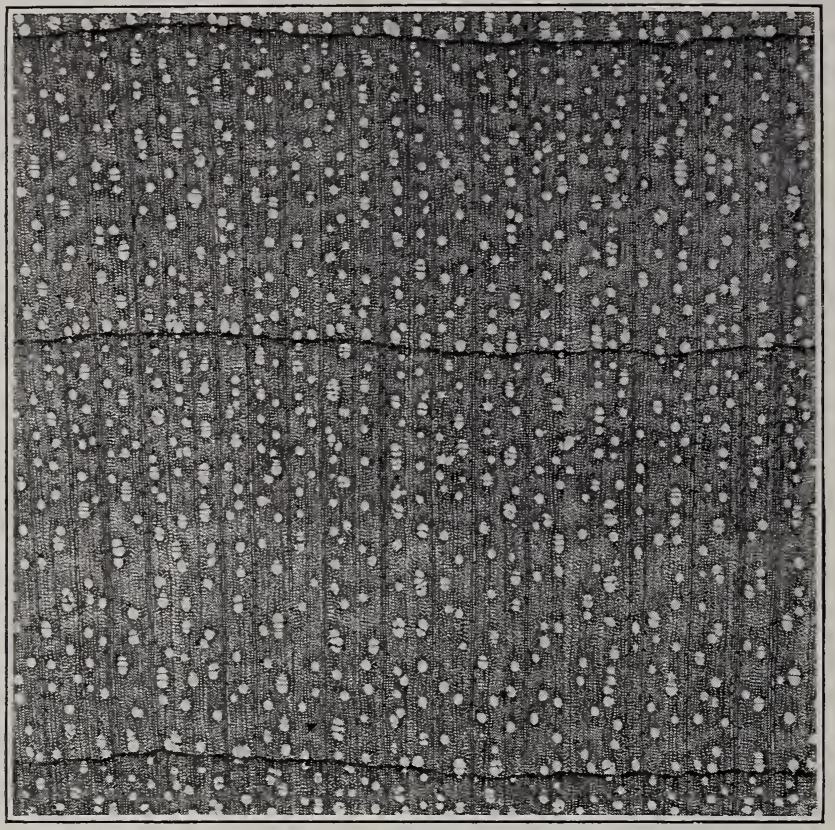

FIG. 1.-SILVER MAPLE.

Cross section magnified 15 diameters.

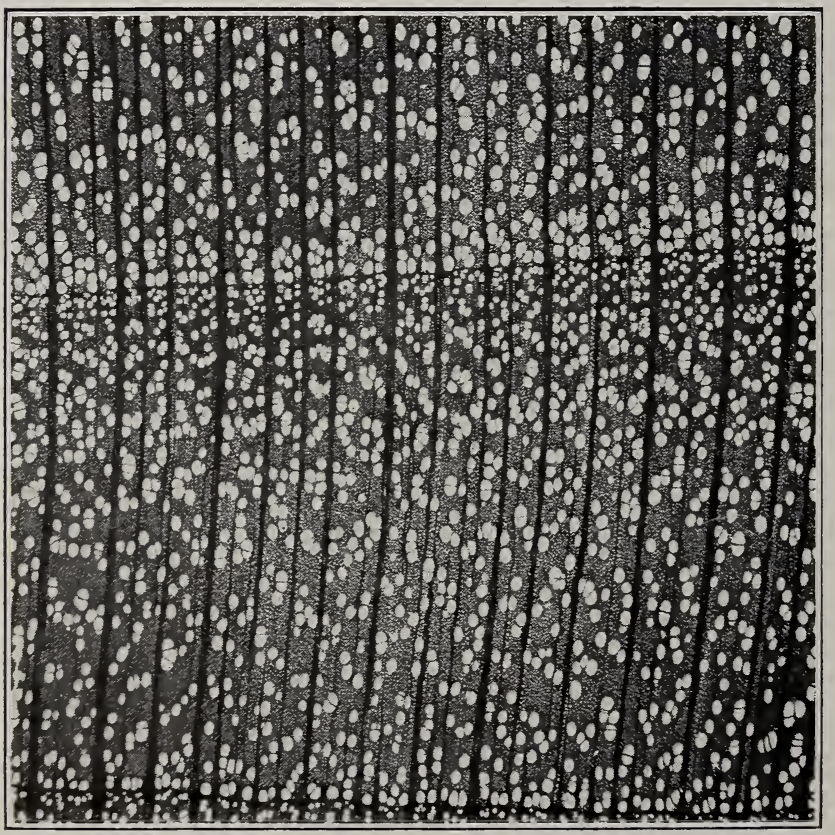

FIG. 2.-BLACK CHERRY.

Cross section magnified 15 diameters. 


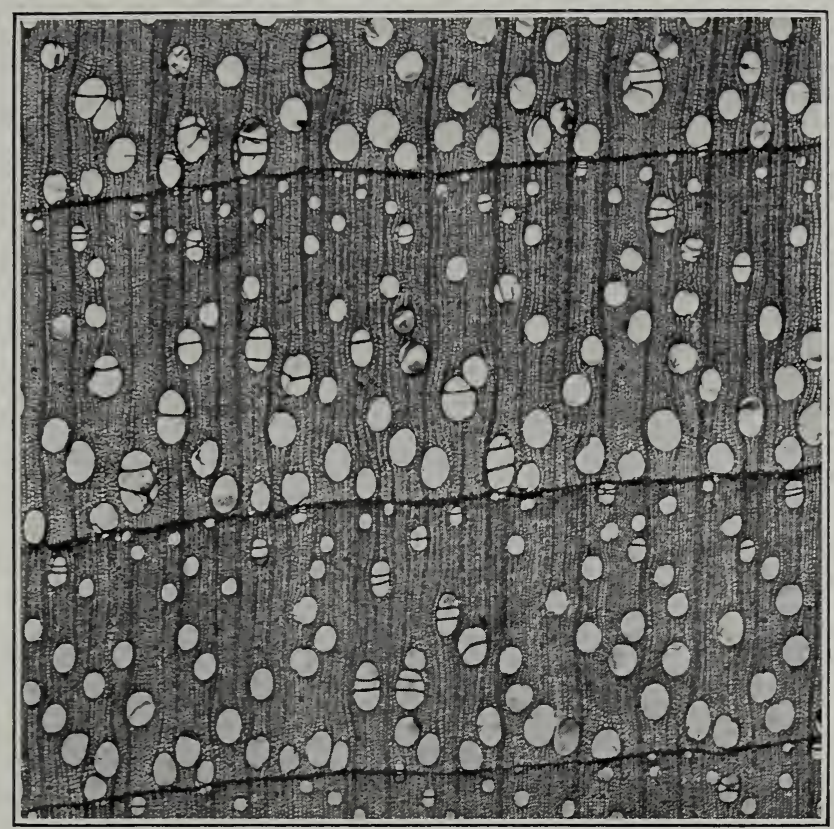

FIG. 1.-BLACK WALnUt.

Cross section magnified 15 diameters.

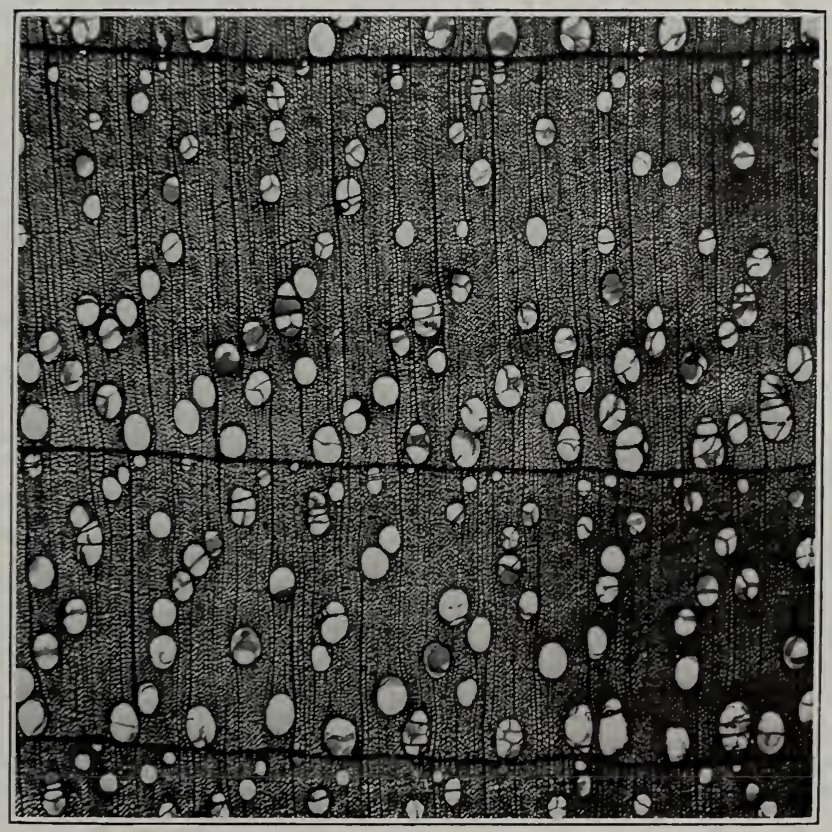

FIG. 2.-BUTtERNUT.

Cross section magnified 15 diameters. 


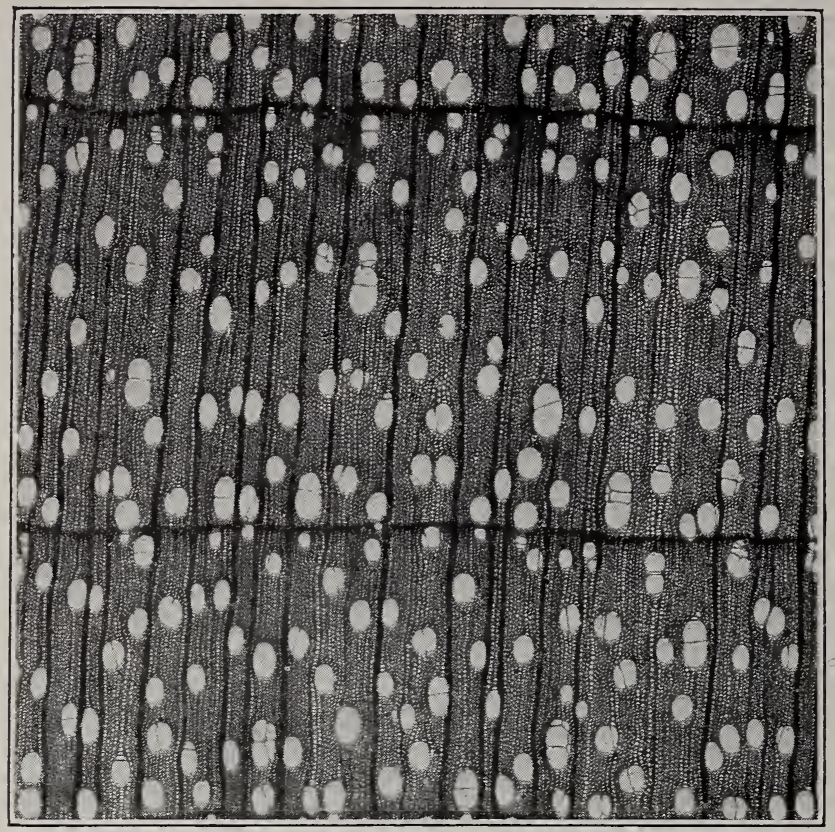

FIG. 1.-YELLOW BIRCH.

Cross section magnified 15 diameters.

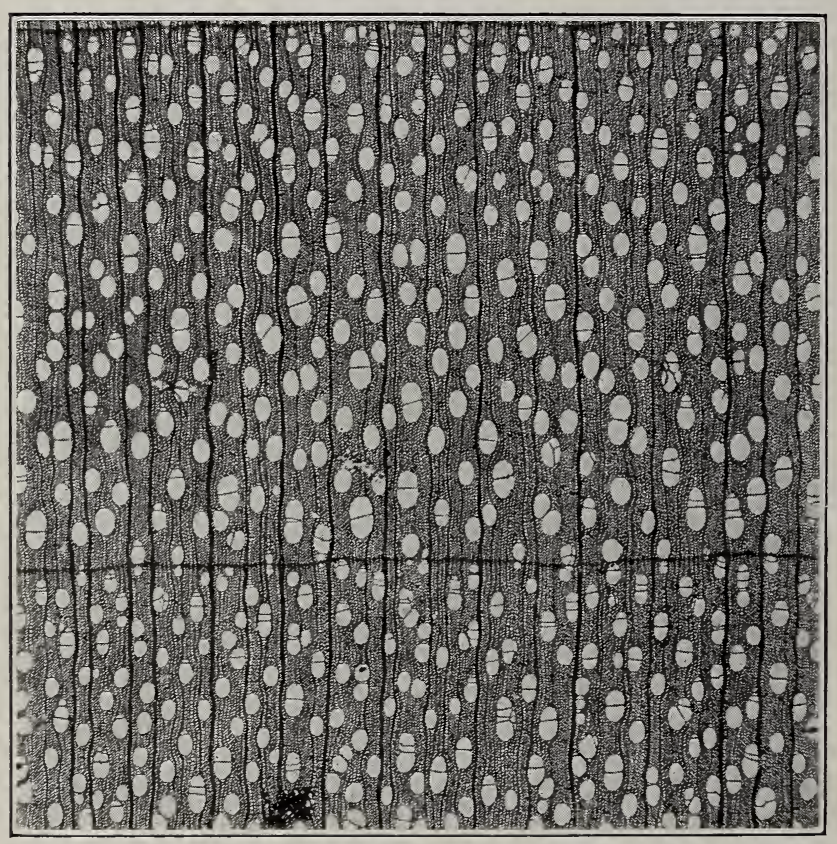

FIG. 2.-RIVER BIRCH.

Cross section magnified 15 diameter's. (Note pith fleck at lower edge.) 


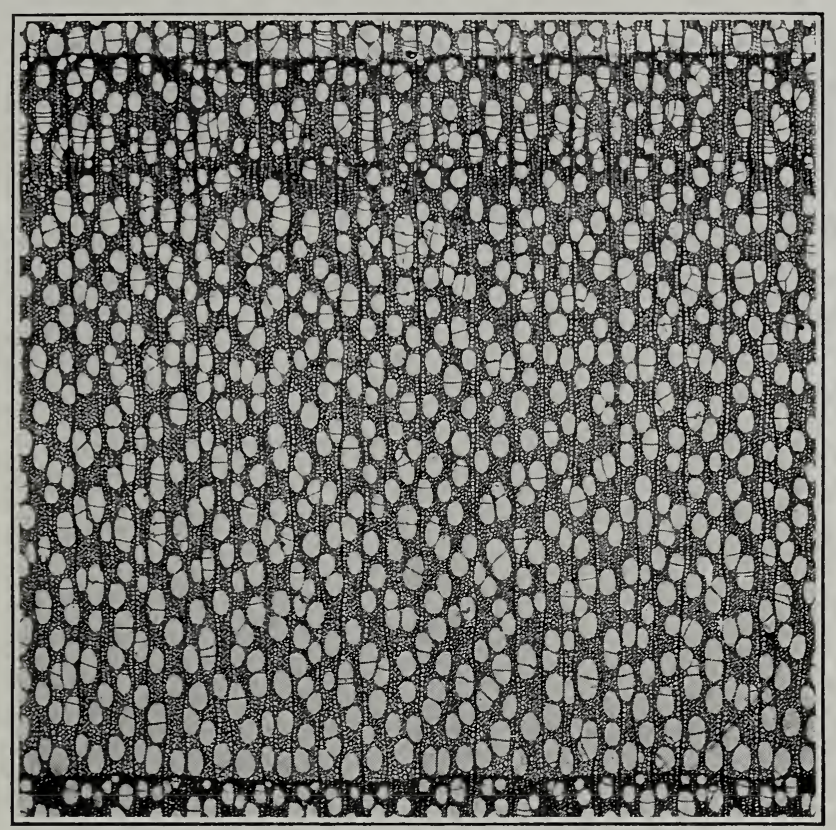

FIG. 1.-COTTONWOOD.

Cross section magnified 15 diameters.

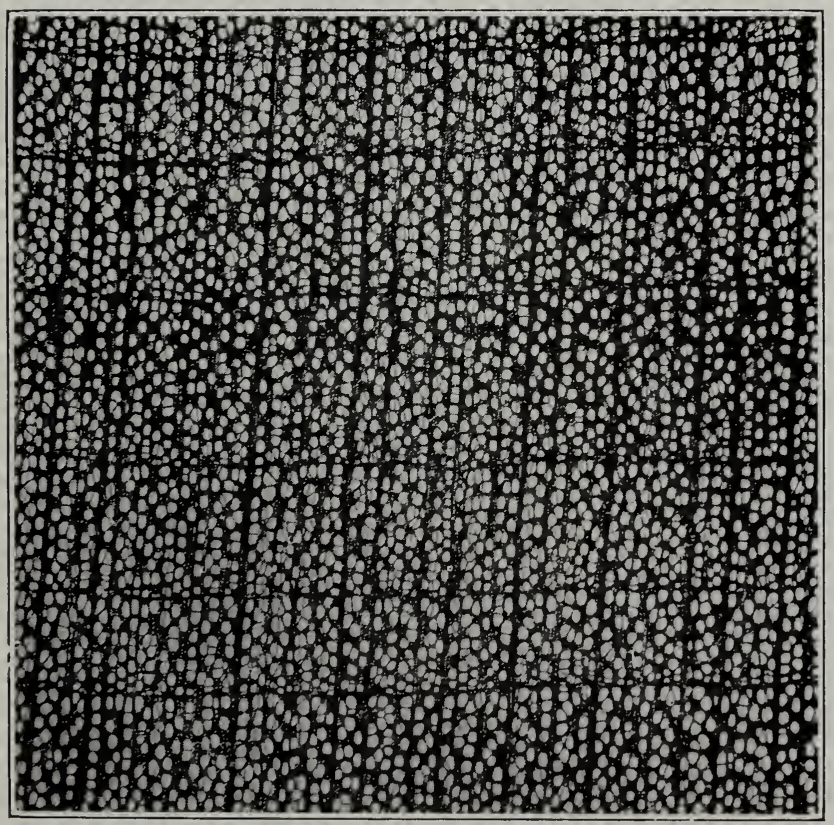

FIG. 2.-RED GUM.

Cross section magnified 15 diameters. 


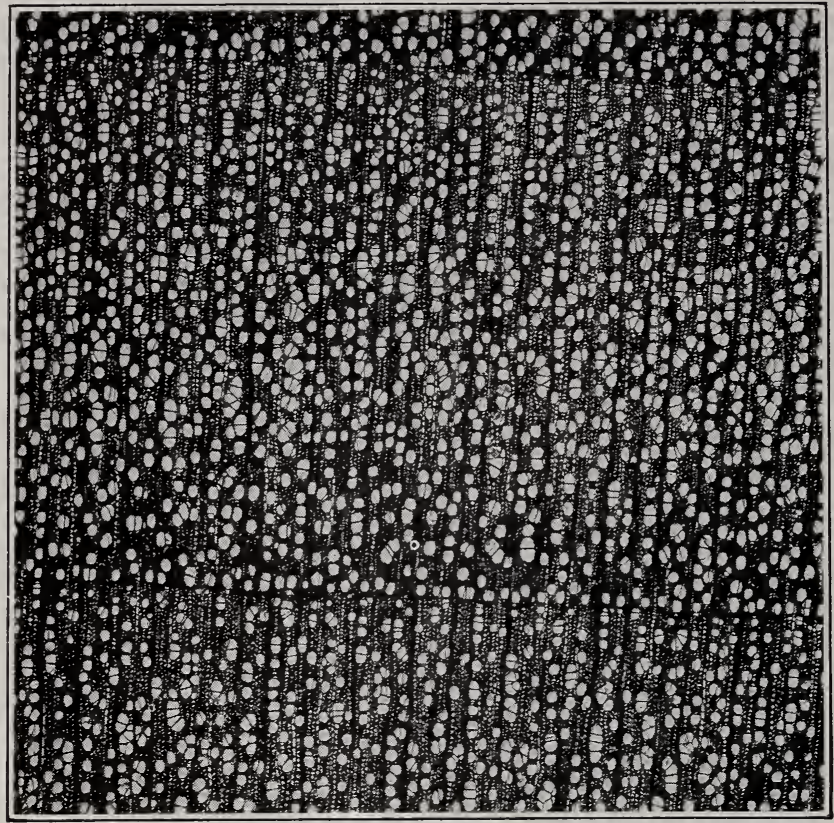

FIG. 1.-BLACK GUM.

Cross section magnified 15 diameters.

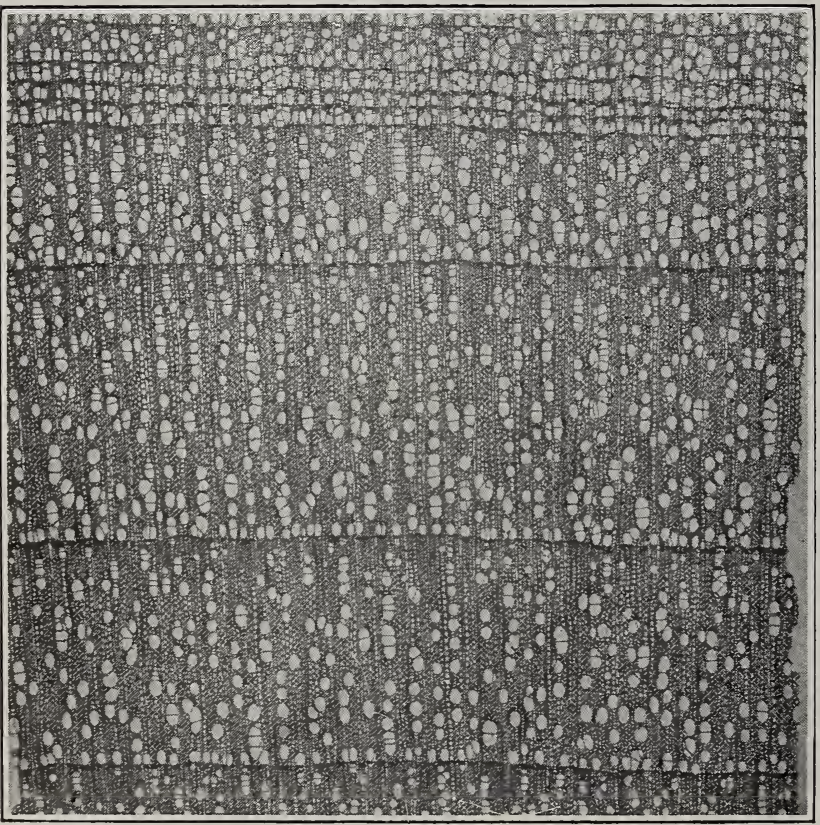

FiQ. 2.-CotTon Gum (TUPelo),

Cross section magnified 15 diameters. 


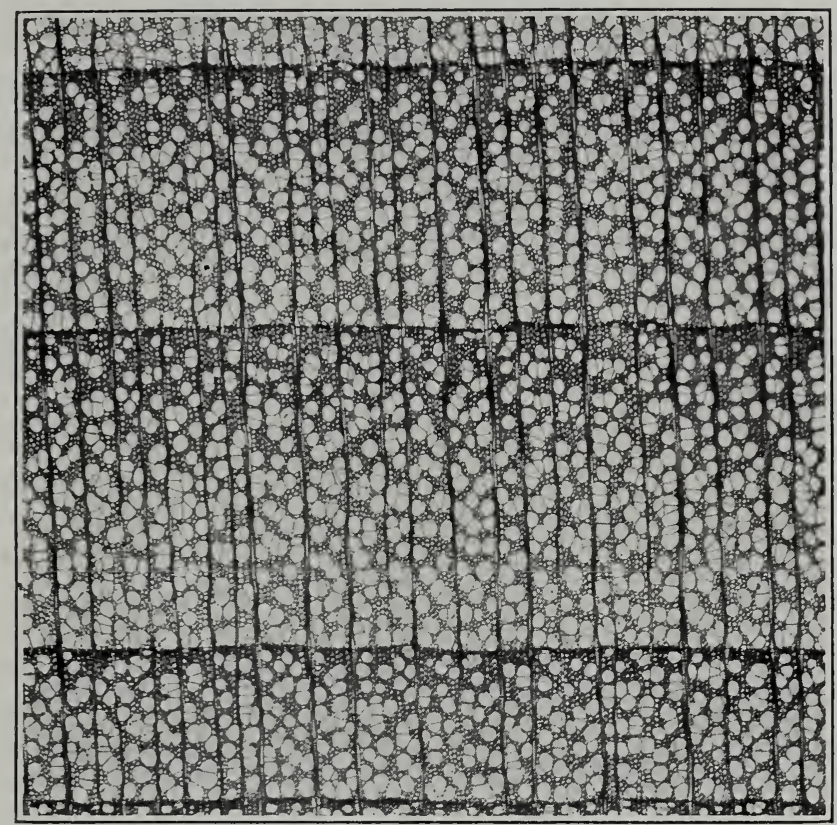

FIG. 1.-YELLOW POPLAR.

Cross section magnified 15 diameters.

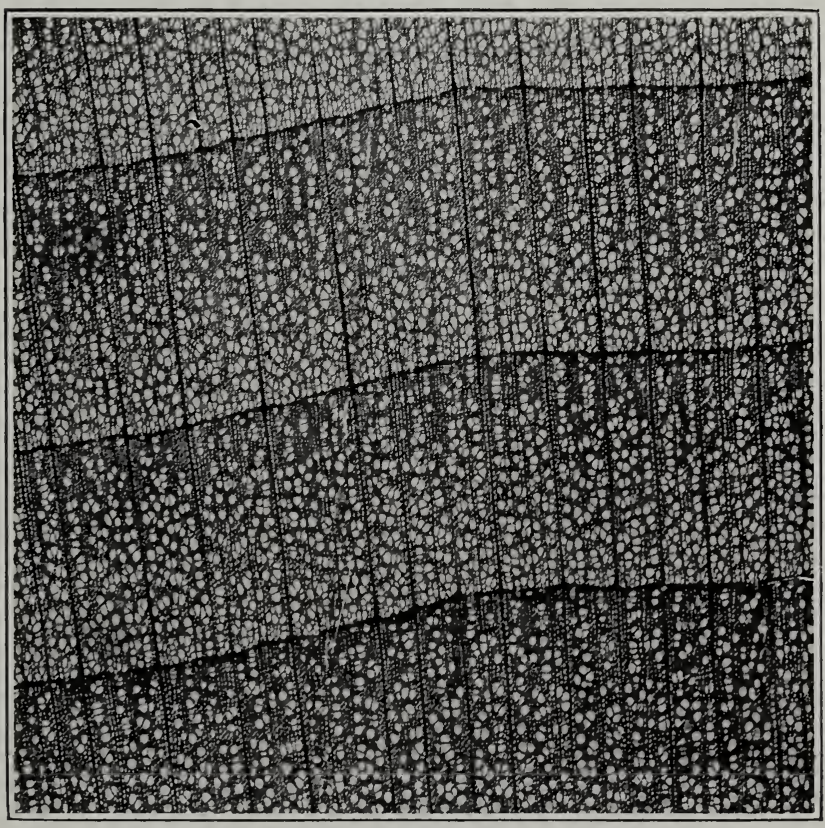

FIG. 2.-BASSWOOD.

Cross section magnilied 15 diameters. 
Forest Service, U. S. Dept. of Agriculture. Identification of Woods

PLATE XXI,

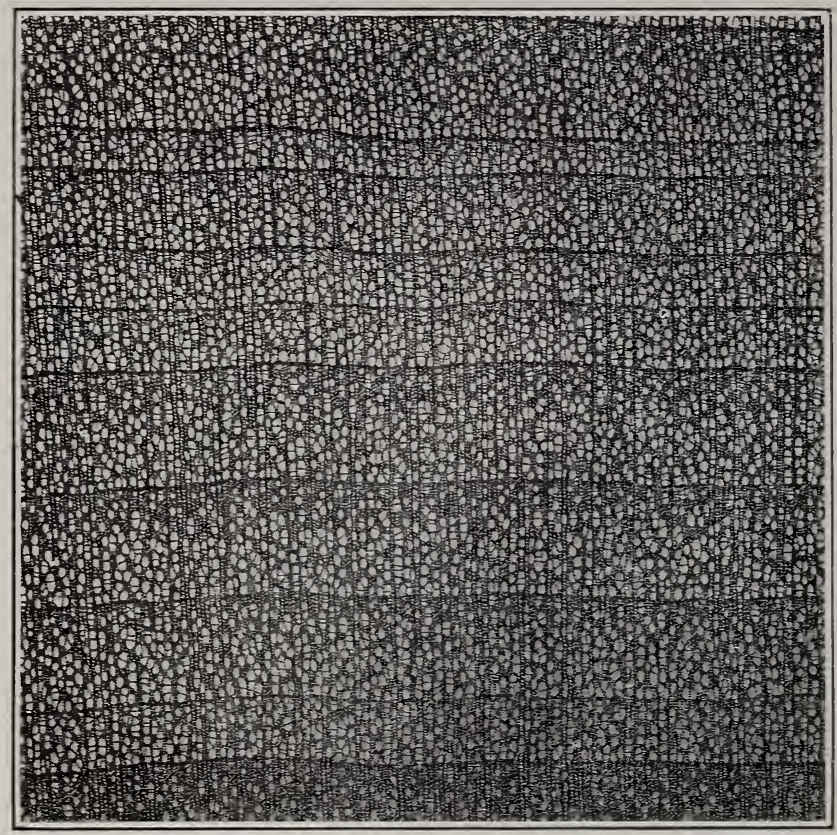

FIG, 1.-YELLOW BUCKEYE.

Cross section magnified 15 diameters.

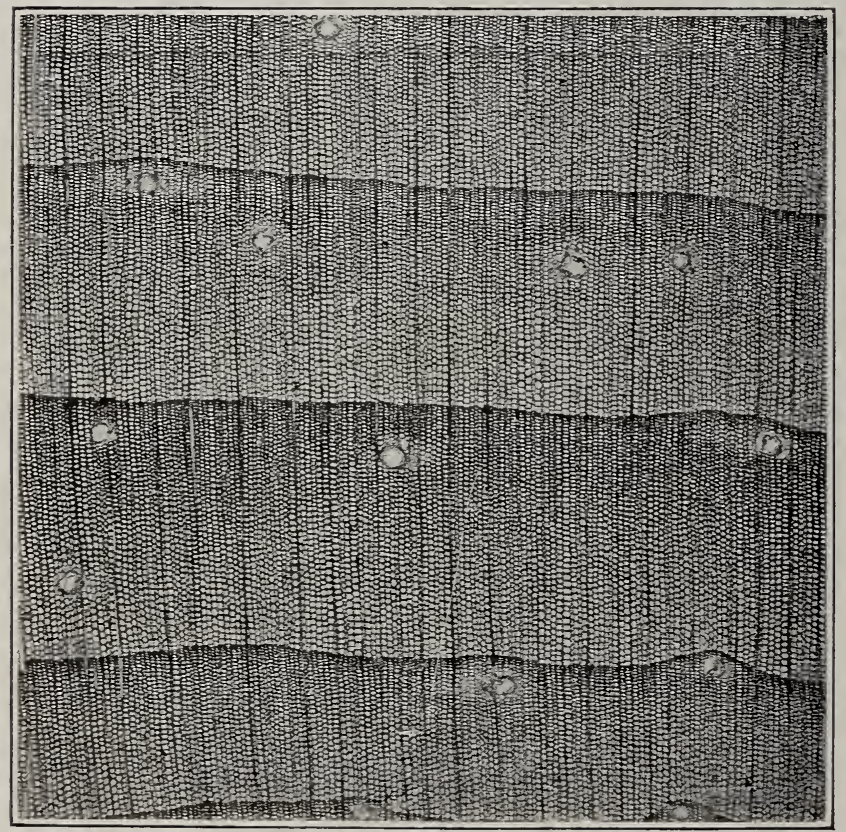

Fig. 2.-Western White Pine.

Cross section magnilied 15 diameters. 


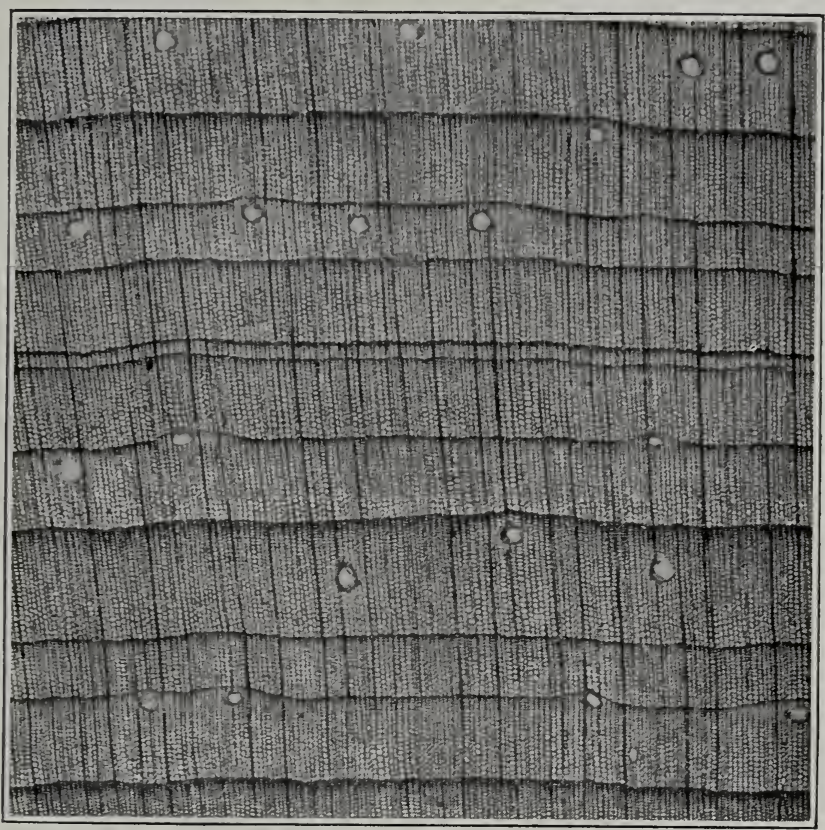

FIG. 1.-LIMBER PINE.

Cross section magnified 15 diameters.

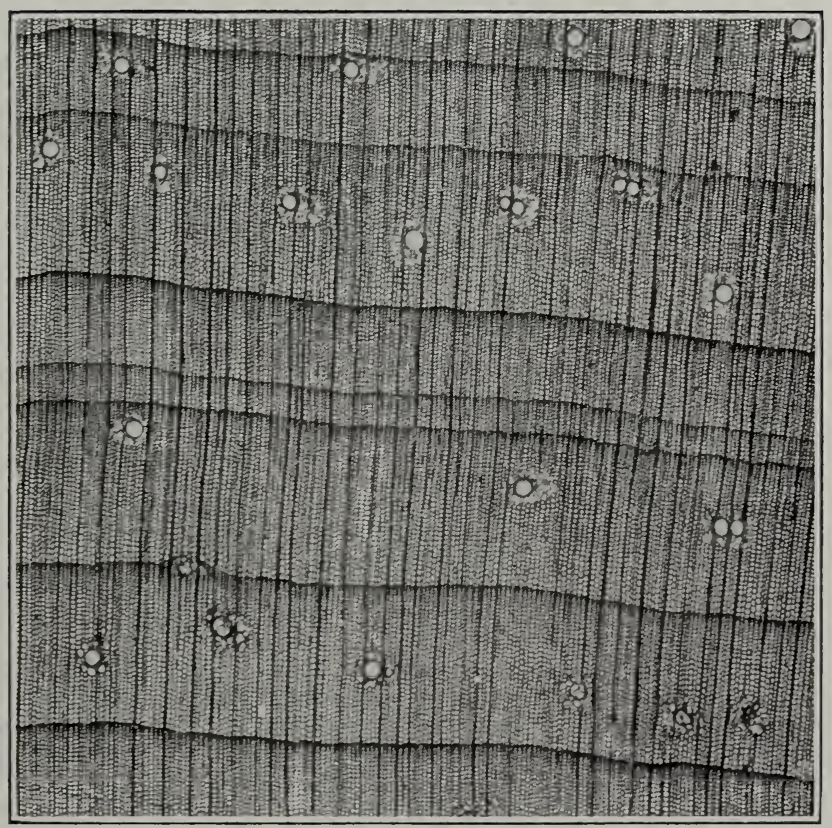

FIG. 2.-PIÑON (PINE).

Cross section magnified 15 diameters. 


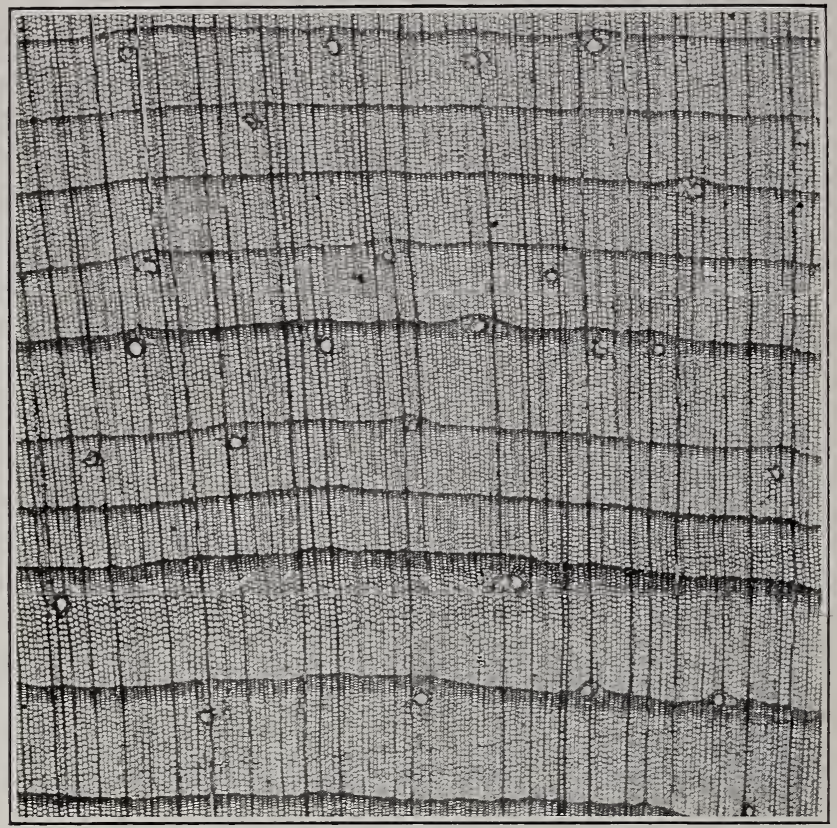

Fig. 1.-Lodgepole Pine.

Cross section magnified 15 diameters.

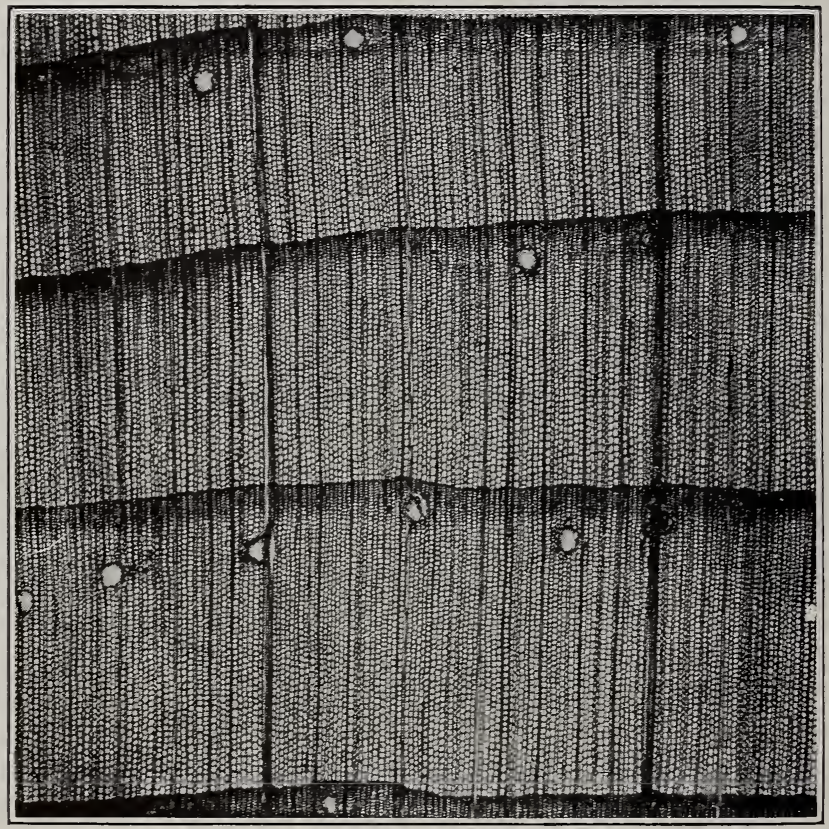

Fig. 2.-Western Yellow Pine.

Cross section magnified 15 diameters. 
Forest Service, U. S. Dept. of Agriculture. Identification of Woods.

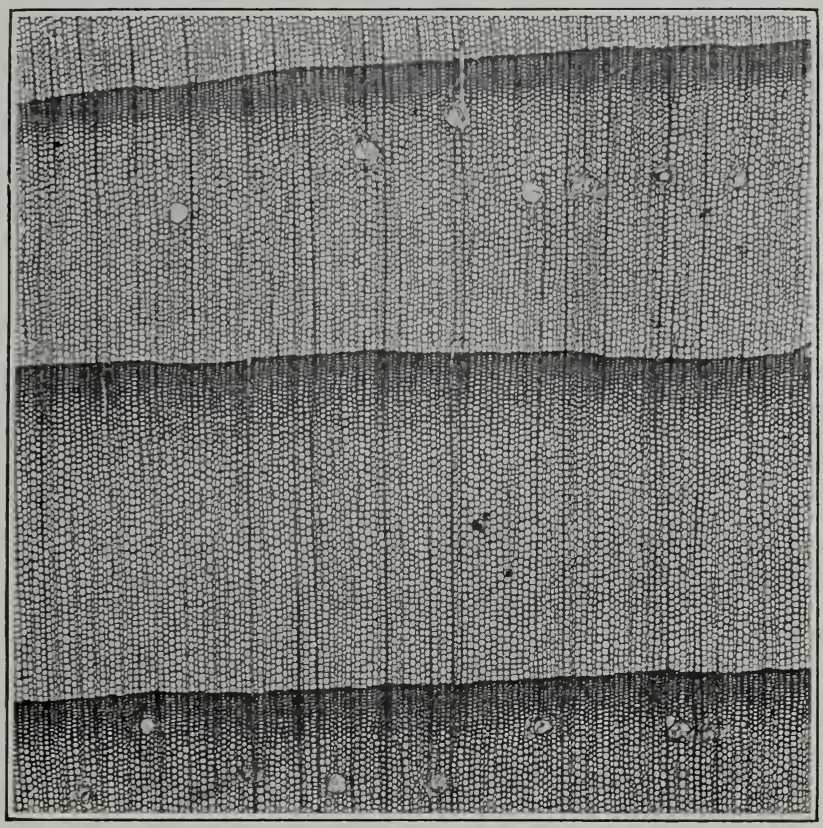

FIG. 1.-NORWAY PINE.

Cross section magnified 15 diameters.

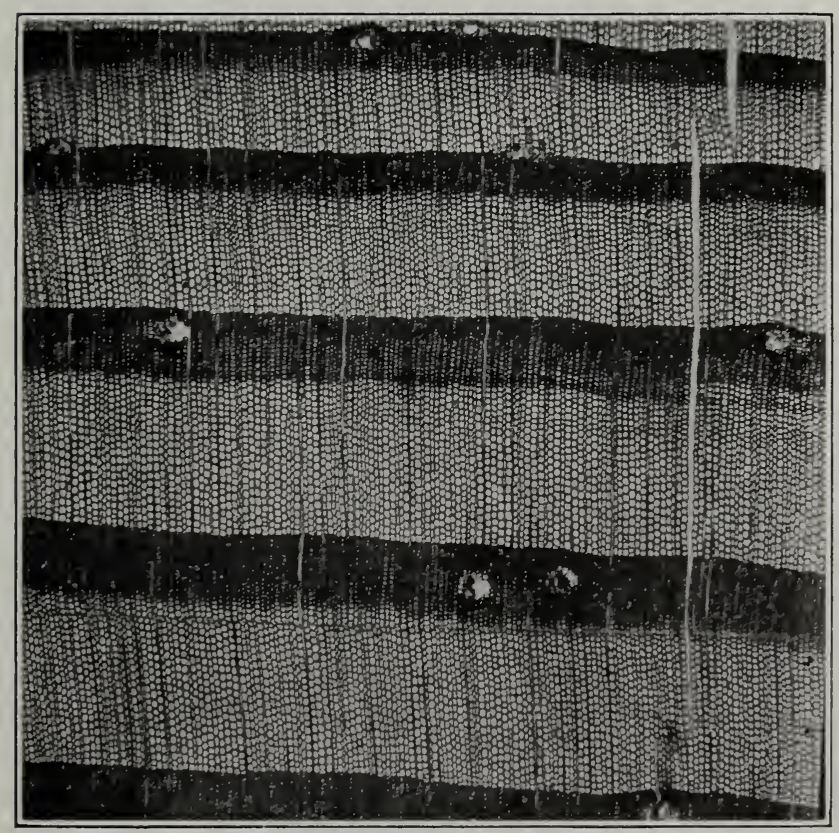

FIG. 2.-SHORTLEAF PINE.

Cross section magnified 15 diameters. 
Forest Service, U. S. Dept. of Agriculture. Identification of Woods.

PLATE XXV.

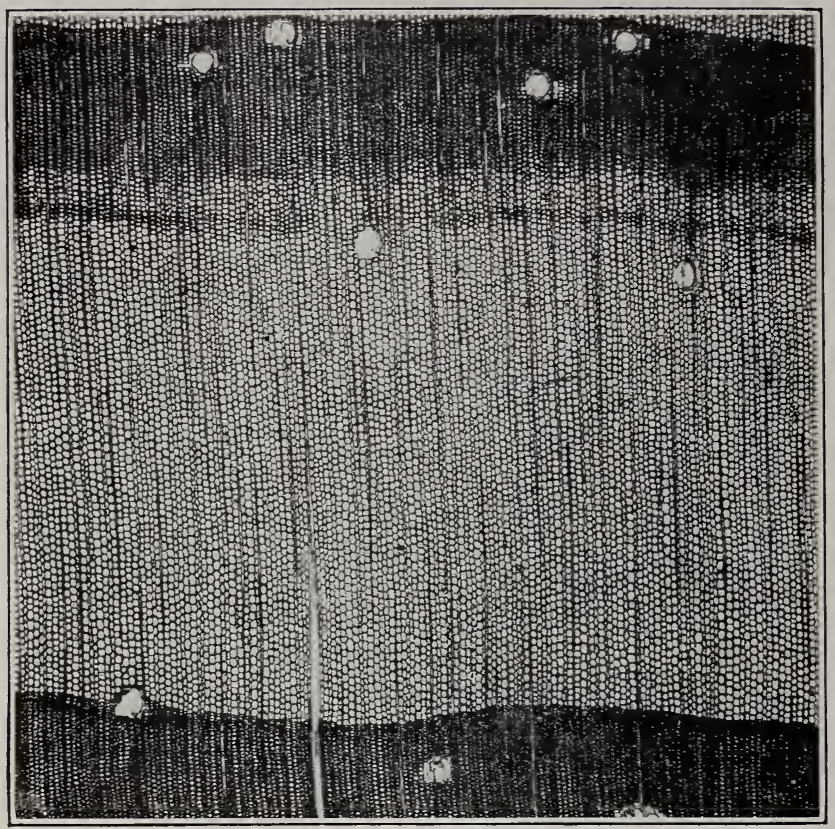

FIG. 1.-LOBLOLLY PINE.

Cross section magnified 15 diameters.

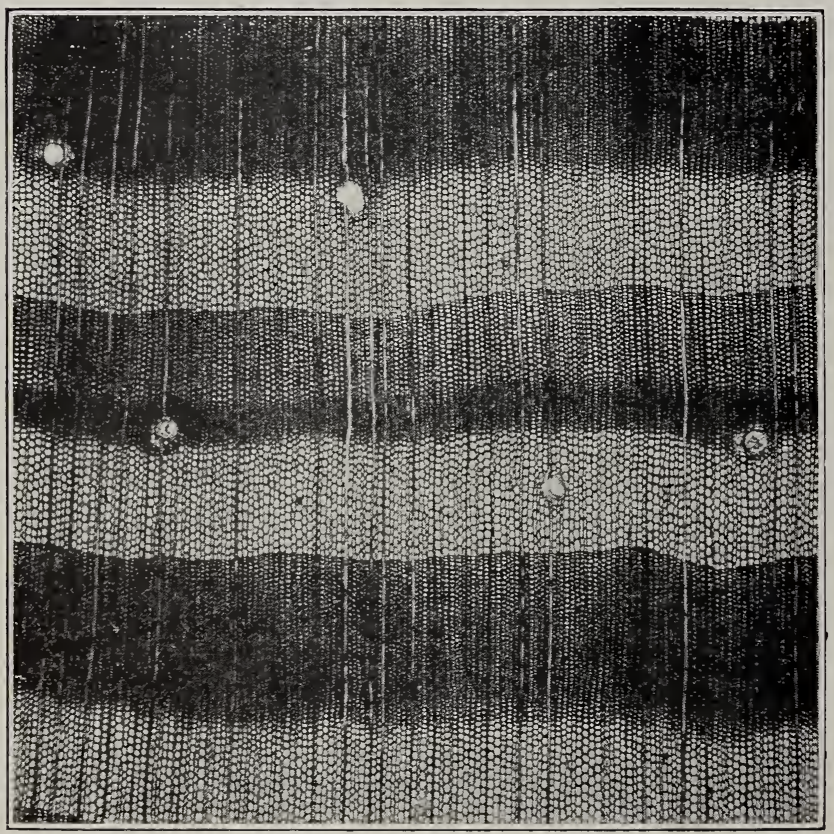

FIG. 2.-LONGLEAF PINE.

Cross section magnified 15 diameters. 
Forest Service, U. S. Dept. of Agriculture. Identification of Woods.

PLATE XXVI.

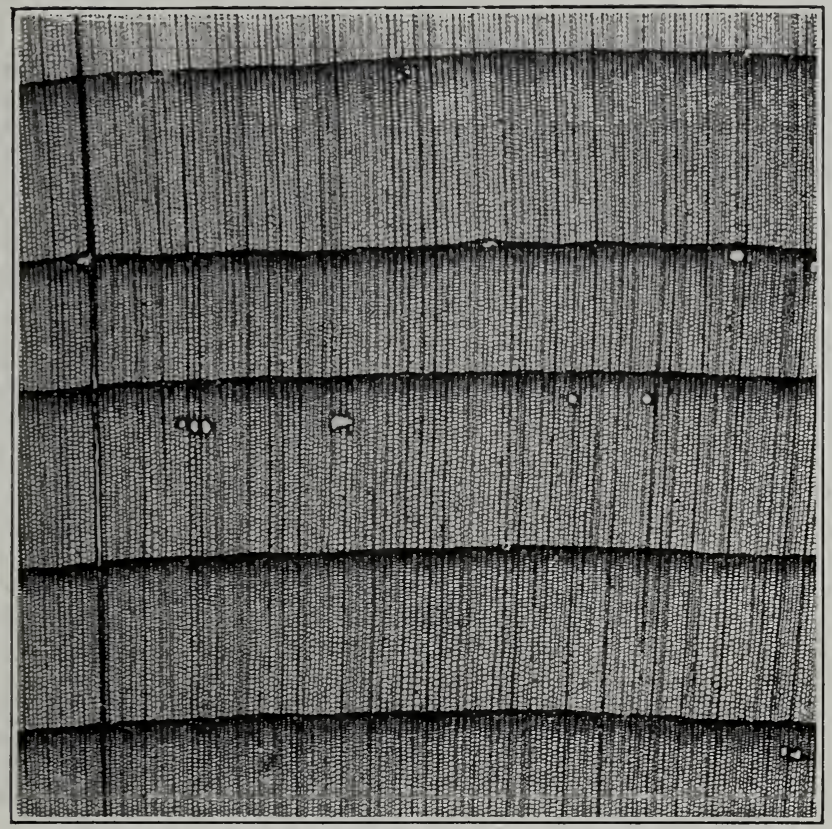

FIG. 1.-ENGeLmann SPRUCE.

Cross section magnified 15 diameters.

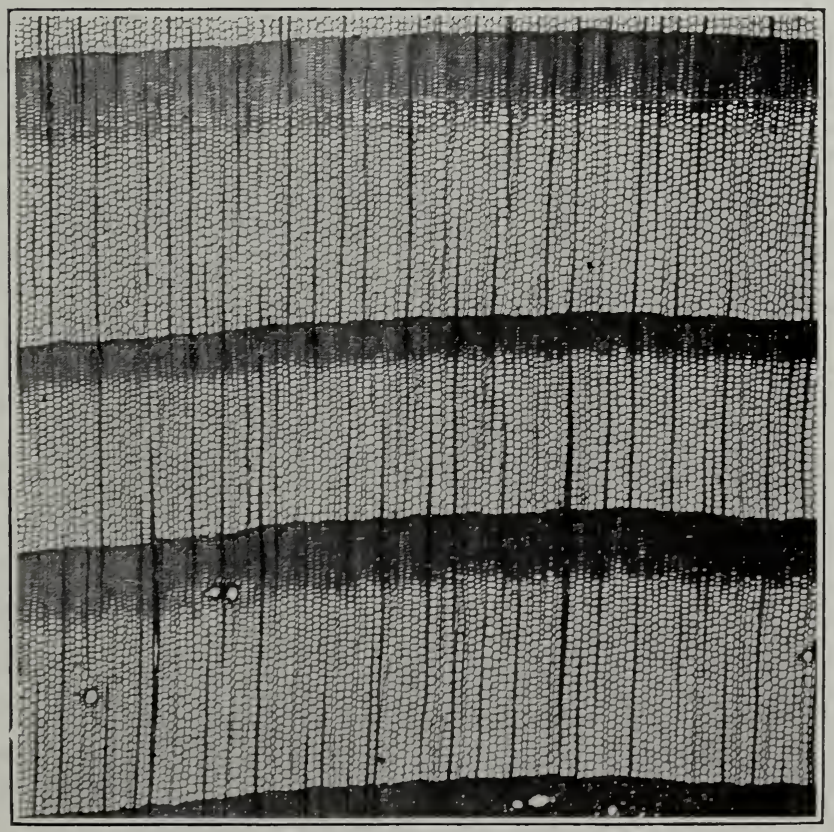

FiG. 2.-DOUGLAS FIR.

Cross section magnified 15 diameters. 


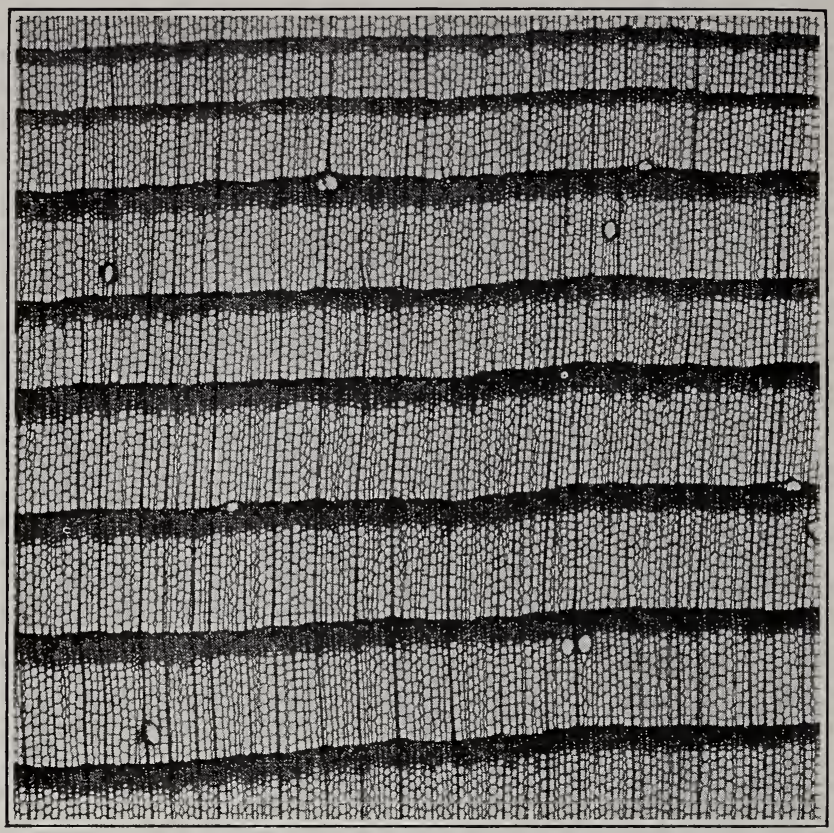

Fig. 1.-WESTERN LARCH.

Cross section magnified 15 diameters.

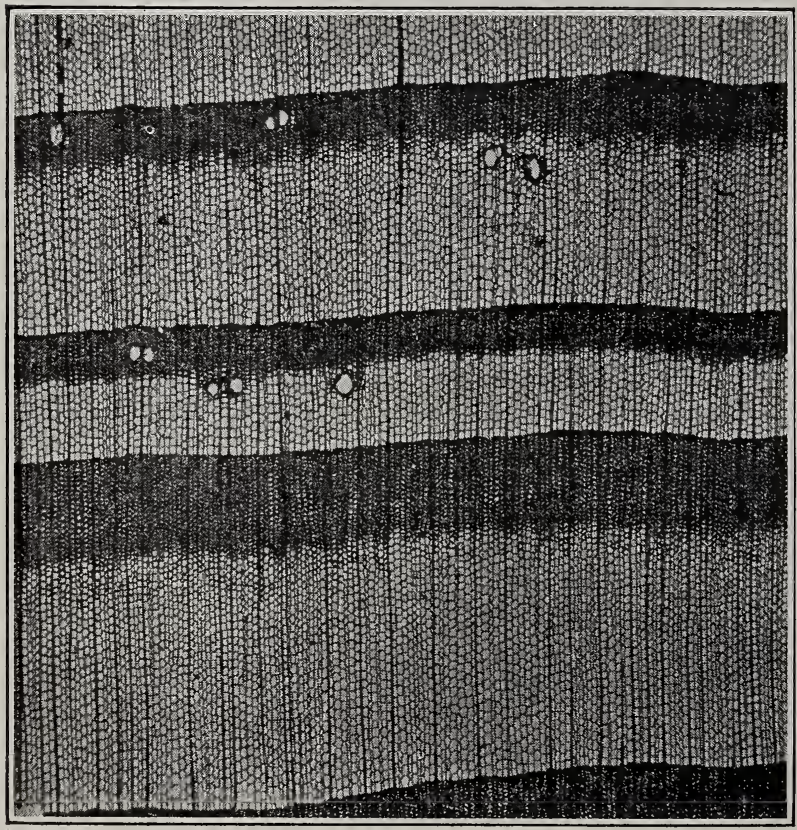

FIQ. 2.-TAMARACK.

Cross section magnified 15 diameters. 


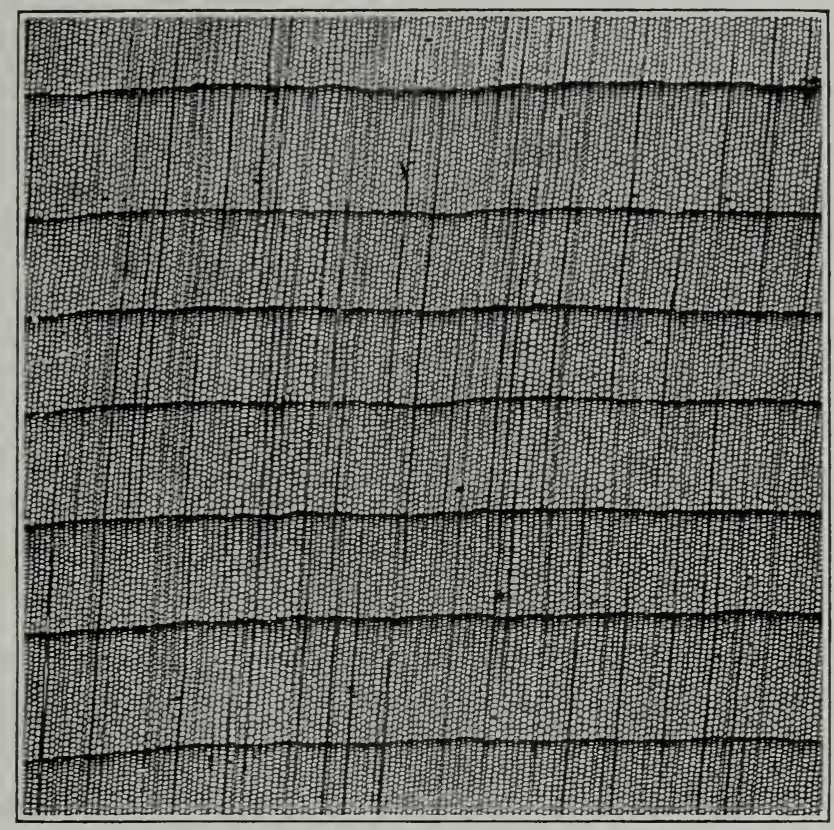

FIG. 1.-PORT ORFORD CEDAR.

Cross section magnified 15 diameters.

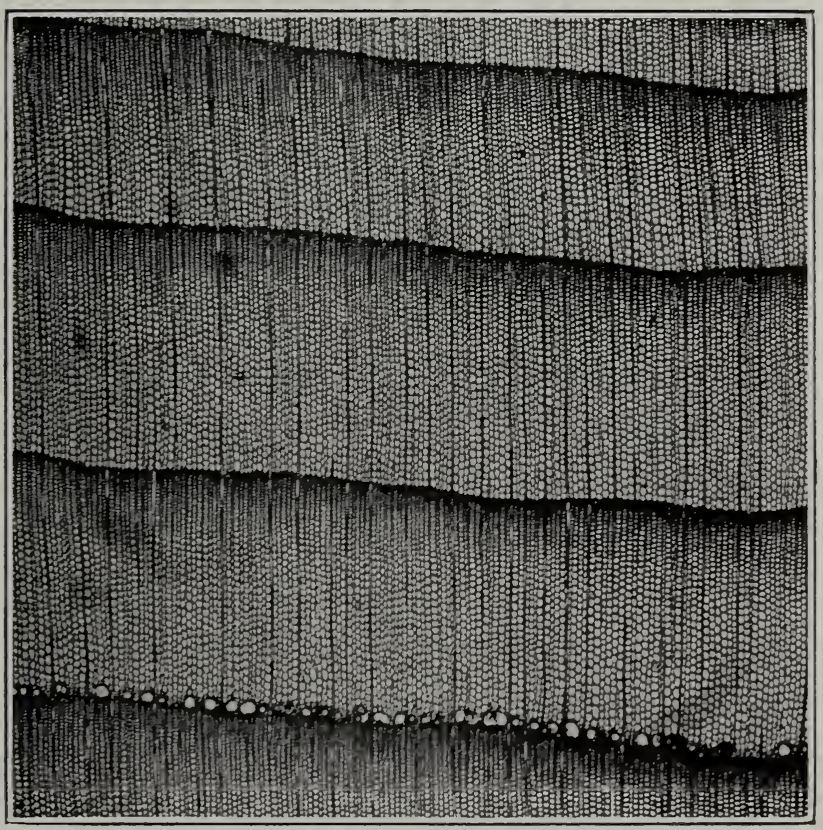

FIG. 2.-WHITE FIR.

Cross section magnified 15 diameters.

(Note row of abnormal resin ducts in lower portion.) 


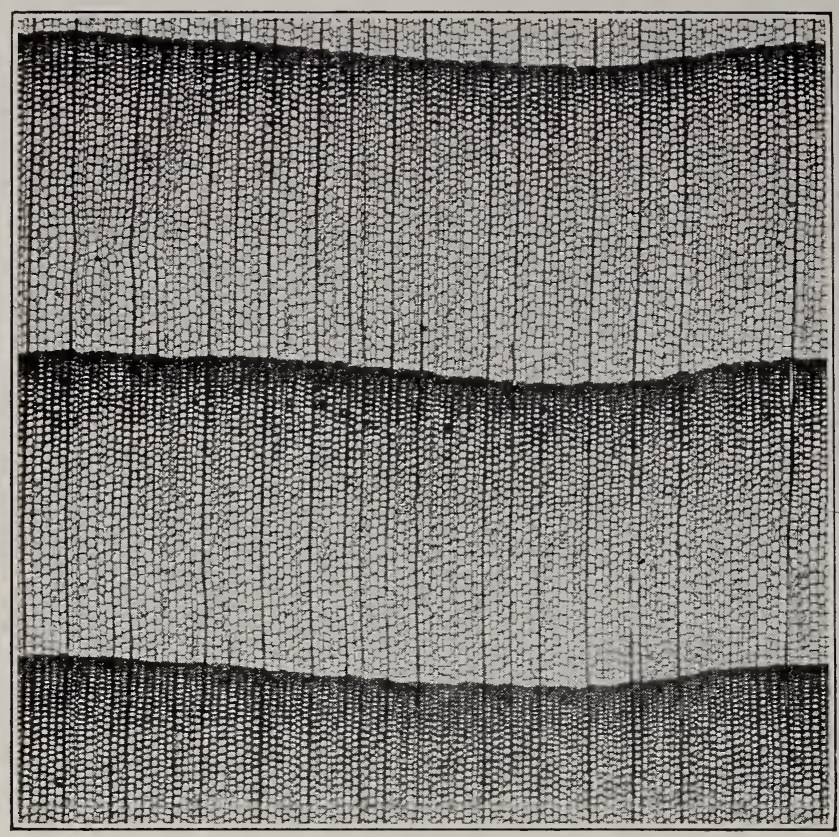

FIG. 1.-GRAND FIR.

Cross section magnified 15 diameters.

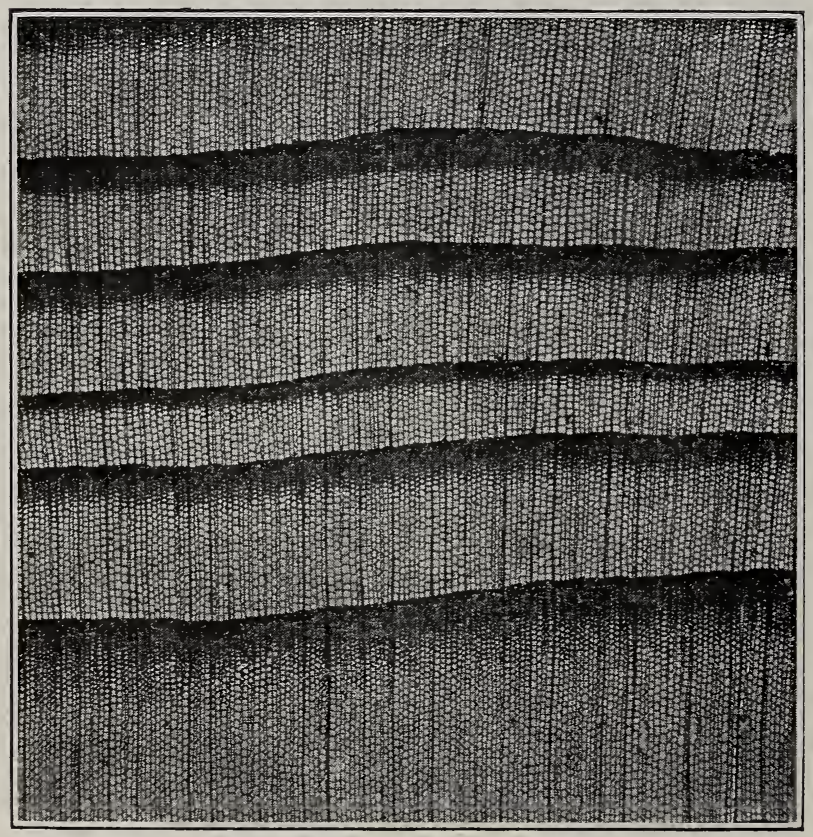

Fig. 2.-Eastern Hemlock.

Cross section magnified 15 diameters. 
Forest Service, U. S. Dept. of Agriculture. Identification of Woods.

PLATE $X X X$.

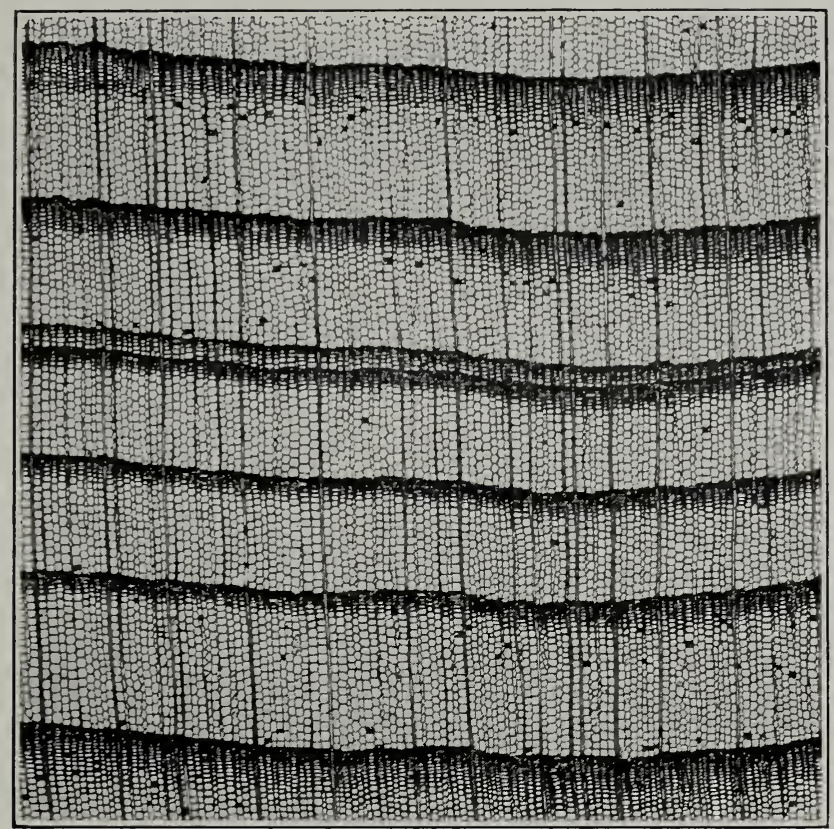

FIQ. 1.-REDWOOD.

Cross section magnified 15 diameters.

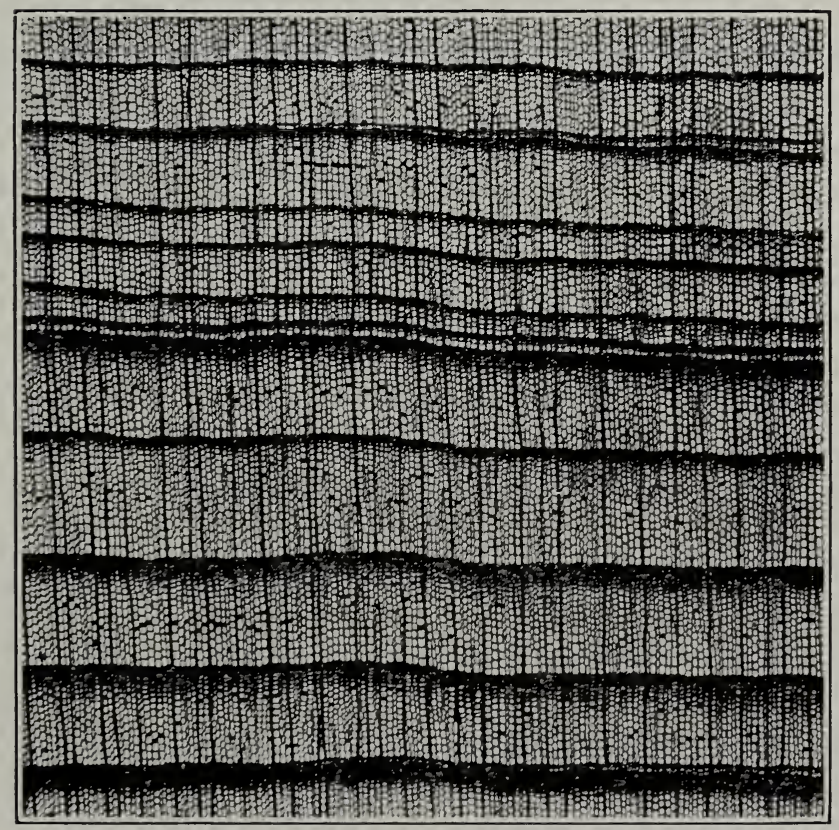

FIG. 2.-BALD CYPRESS.

Cross section magnified 1.j diameters. 
Forest Service, U. S. Dept. of Agriculture. Identification of Woods.

Plate XXXI.

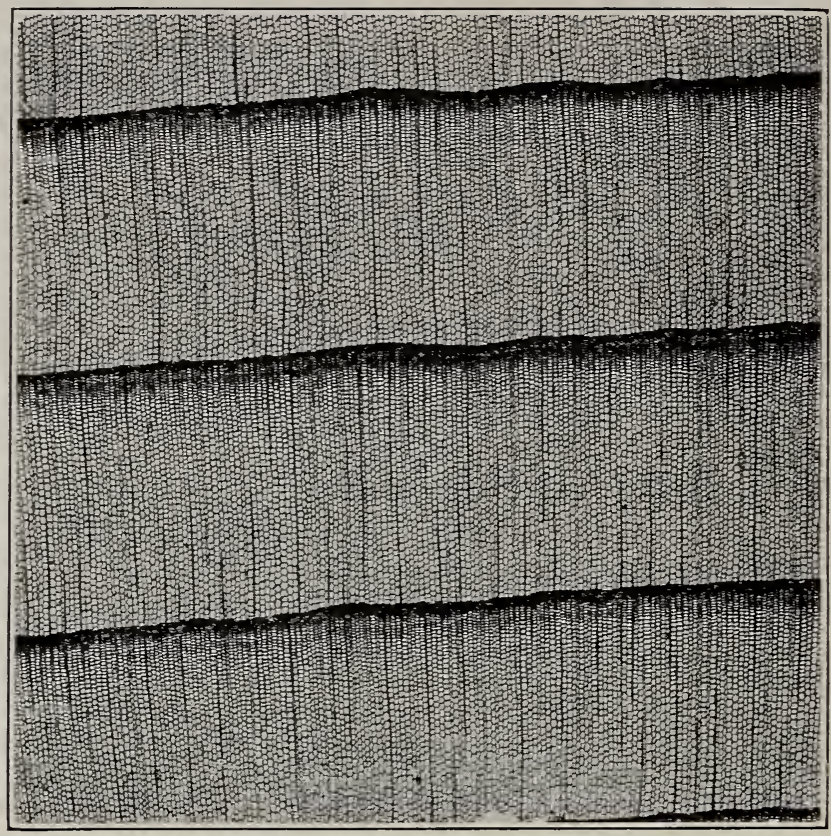

Fig. 1.-Western Red Cedar.

Cross section magnified 15 diameter's.

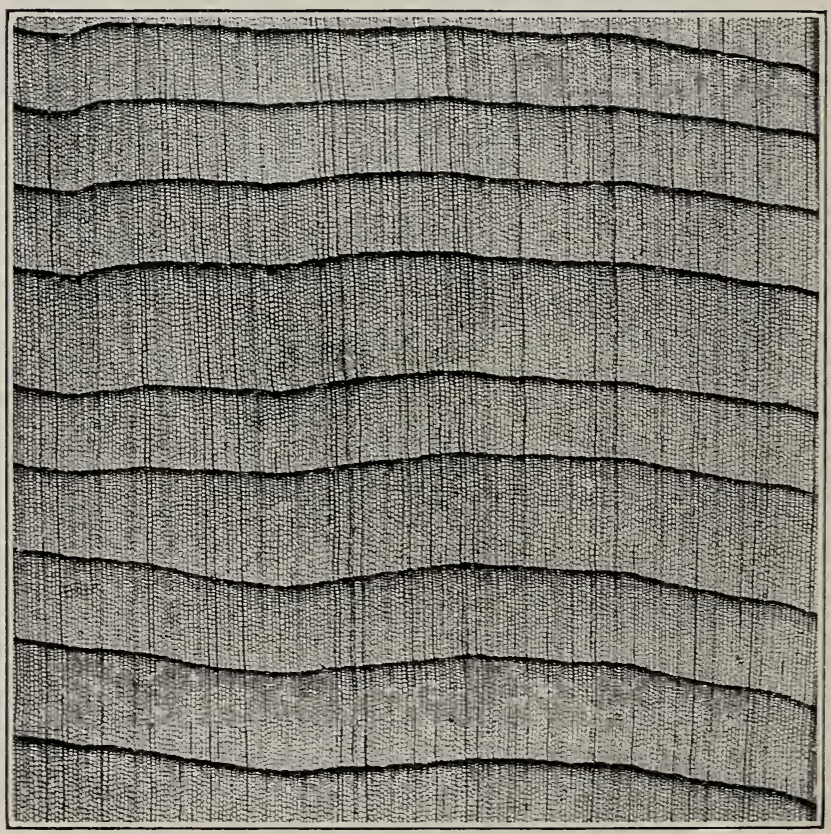

Fia. 2.-Arborvite (Northern White Cedar).

Cross section magnified 15 diameters. 


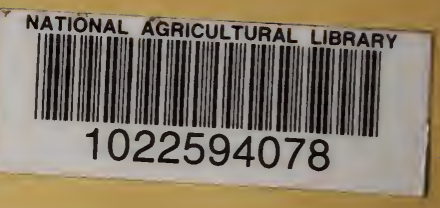

